\title{
HYDROGEOLOGY AND SIMULATED GROUND- WATER FLOW IN THE AREA OF GREENWICH TOWNSHIP, GLOUCESTER COUNTY, NEW JERSEY
}

By Amleto A. Pucci, Jr., Cynthia Barton, and Herbert T. Buxton

$+$

U.S. GEOLOGICAL SURVEY

Open-File Report 95-716

Prepared in cooperation with

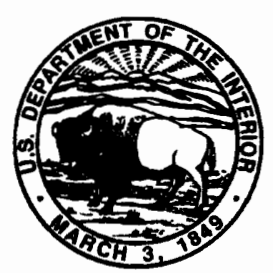

GREENWICH TOWNSHIP, NEW JERSEY, and the NEW JERSEY DEPARTMENT OF ENVIRONMENTAL PROTECTION 


\title{
U.S. DEPARTMENT OF THE INTERIOR \\ BRUCE BABBITT, Secretary
}

\author{
U.S. GEOLOGICAL SURVEY
}

Gordon P. Eaton, Director

For additional information write to:

District Chief U.S Geological Survey Mountain View Office Park 810 Bear Tavern Road, Suite 206 West Trenton, NJ 08628
Copies of this report can be purchased from:

U.S. Geological Survey Branch of Information Services Box 25286

Denver, CO 80225-0286 


\section{CONTENTS}

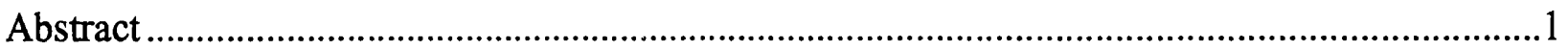

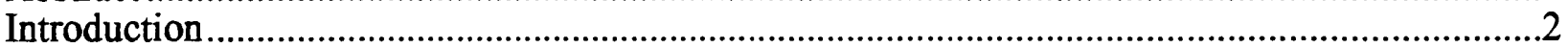

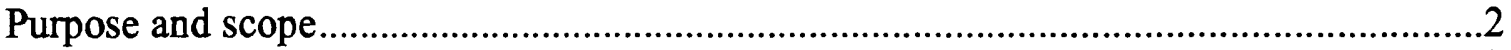

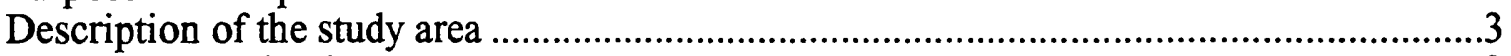

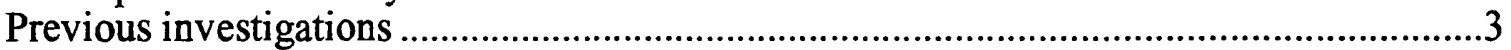

Acknowledgments.....................................................................................................

Hydrogeology ........................................................................................................................6

Hydrogeologic units ........................................................................................................6

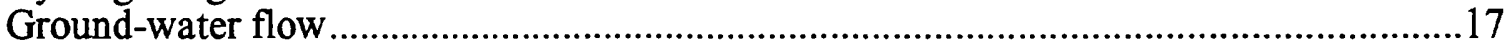

Predevelopment conditions...................................................................................20

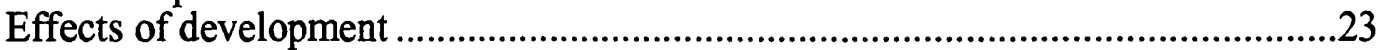

Simulated ground-water flow.......................................................................................................2

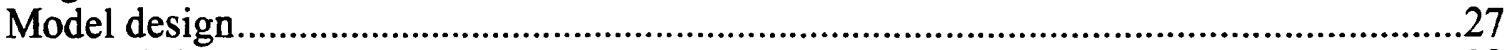

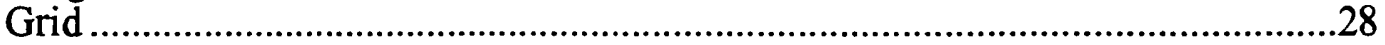

Temporal assumptions ...................................................................................28

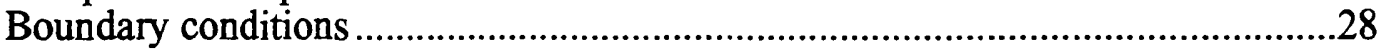

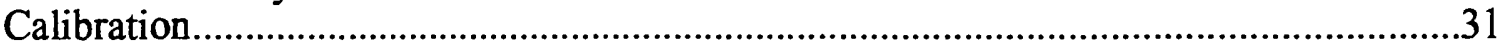

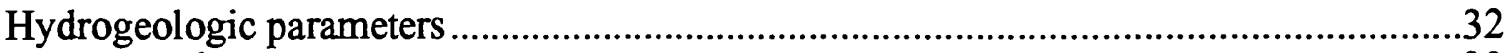

Recharge ……..............................................................................................32

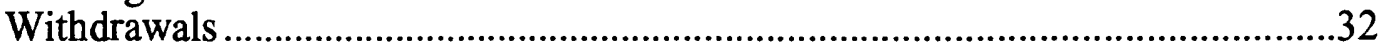

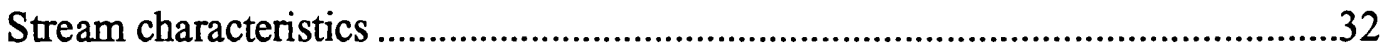

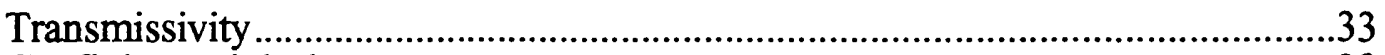

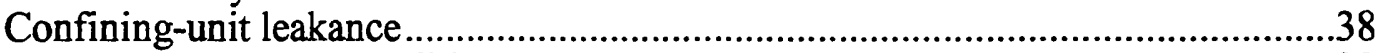

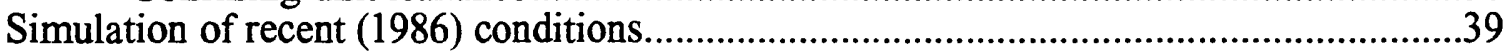

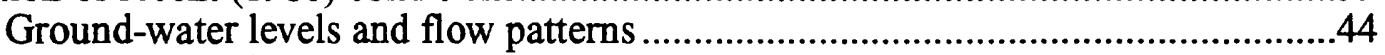

Ground-water budget ..................................................................................54

Hydrologic considerations for additional ground-water development ...............................57

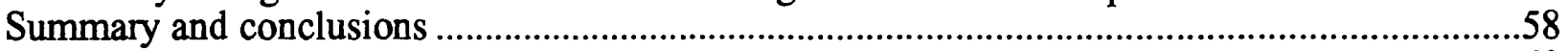

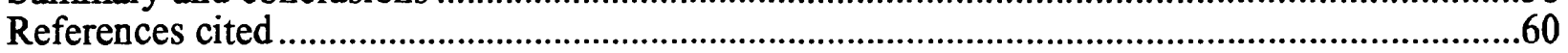

\section{ILLUSTRATIONS}

Figure 1. Map showing location of the study area and physiographic provinces ......................4

2. Map of the Greenwich Township, New Jersey, study area ......................................5

3. Generalized hydrogeologic sections through the major hydrogeologic units in the study area ...........................................................................................................

4-12. Maps showing altitude of the:

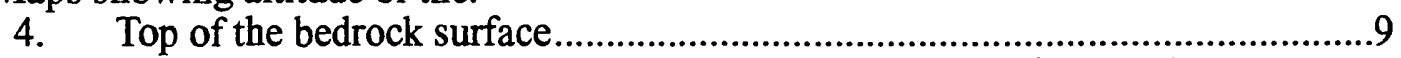

5. Top of the lower aquifer of the Potomac-Raritan-Magothy aquifer system...

6. Top of the confining unit between the middle and lower aquifers of the Potomac-Raritan-Magothy aquifer system

7. Top of the lower part of the middle aquifer of the Potomac-RaritanMagothy aquifer system.

8. Top of the confining unit dividing the middle aquifer of the Potomac-

Raritan-Magothy aquifer system.

9. Top of the upper part of the middle aquifer of the Potomac-RaritanMagothy aquifer system. 


\section{ILLUSTRATIONS--Continued}

Page

Figure 10. Top of the confining unit between the upper and middle aquifers of the Potomac-Raritan-Magothy aquifer system 16

11. Top of the upper aquifer of the Potomac-Raritan-Magothy aquifer system

12. Top of the Merchantville-Woodbury confining unit

13. Generalized hydrogeologic sections through the major hydrogeologic units in the study area depicting the ground-water-flow system under predevelopment conditions

14. Maps showing ground-water-flow patterns in the (a) upper aquifer of the Potomac-Raritan-Magothy aquifer system and (b) Englishtown aquifer system under predevelopment conditions....

15. Maps showing potentiometric surface in the (a) upper aquifer of the PotomacRaritan-Magothy aquifer system and (b) Englishtown aquifer system in 1988

16. Graph showing total rate of withdrawal and rates of withdrawal from the upper, middle, and lower aquifers of the Potomac-Raritan-Magothy aquifer system in the study area, $1956-86$.

17. Generalized hydrogeologic sections through the study area depicting the ground-water-flow system under developed conditions

18. Schematic section through model layers showing hydrogeologic units and boundary conditions used in the model

19. Finite-difference grid, locations of stream and river cells, and simulated updip extents of the Merchantville-Woodbury confining unit and Englishtown aquifer system....

20-23. Maps showing transmissivity of the:

20. Upper aquifer of the Potomac-Raritan-Magothy aquifer system (model layer 1), and the unconfined area of the middle and lower aquifers of the Potomac-Raritan-Magothy aquifer system and the overlying upper Cenozoic deposits (model layers 1-4).

21. Confined area of the upper part of the middle aquifer of the PotomacRaritan-Magothy aquifer system (model layer 2).

22. Confined area of the lower part of the middle aquifer of the PotomacRaritan-Magothy aquifer system (model layer 3 ).

23. Confined area of the lower aquifer of the Potomac-Raritan-Magothy aquifer system (model layer 4)

24-27. Maps showing leakance of the:

24. Merchantville-Woodbury confining unit

25. Confining unit between the upper and middle aquifers of the PotomacRaritan-Magothy aquifer system.

26. Confining unit dividing the middle aquifer of the Potomac-RaritanMagothy aquifer system.

27. Confining unit between the middle and lower aquifers of the PotomacRaritan-Magothy aquifer system.

28-31. Maps showing:

28. Simulated and interpreted potentiometric surface in the upper aquifer of the Potomac-Raritan-Magothy aquifer system and the water table in the outcrop/subcrop area under recent (1986) stressed conditions 


\section{ILLUSTRATIONS--Continued}

Page

Figure 29. Simulated potentiometric surface in the upper part of the middle aquifer of the Potomac-Raritan-Magothy aquifer system under recent (1986) conditions

30. Simulated and interpreted potentiometric surface in the lower part of the middle aquifer of the Potomac-Raritan-Magothy aquifer system under recent (1986) conditions

31. Simulated and interpreted potentiometric surface in the lower aquifer of the Potomac-Raritan-Magothy aquifer system under recent (1986) conditions

32. Diagram showing flow budget for the Potomac-Raritan-Magothy aquifer system in the study area under recent (1986) stressed conditions.

\section{TABLES}

Table 1. Geologic and hydrogeologic units in the area of Greenwich Township,

Gloucester County, New Jersey .8

2. Ground-water budget for the Potomac-Raritan-Magothy aquifer system in the Greenwich Township, New Jersey, study area under recent (1986)

conditions 


\section{CONVERSION FACTORS, ABBREVIATIONS, AND VERTICAL DATUM}

Multiply

inch per year (in/yr)

foot ( $\mathrm{ft}$ )

foot per day $(\mathrm{ft} / \mathrm{d})$

foot per mile ( $\mathrm{ft} / \mathrm{mi}$ )

foot squared per day $\left(\mathrm{ft}^{2} / \mathrm{d}\right)$

square mile $\left(\mathrm{mi}^{2}\right)$

gallon per day (gal/d)

gallons per acre per day

million gallons per day $(\mathrm{Mgal} / \mathrm{d})$
By

2.54

0.3048

0.3048

0.189

0.0929

2.590

0.06309

3.7854

3,785
To obtain

centimeter per day

meter

meter per day

meter per kilometer

meter squared per day

square kilometer

liter per day

liter per acre per day

cubic meter per day

In this report, leakance is expressed in units of $\mathrm{d}^{-1}$ (per day), the simplest form of the expression (ft/d)/ft (foot per day per foot).

Sea level: In this report "sea level" refers to the National Geodetic Vertical Datum of 1929-- a geodetic datum derived from a general adjustment of the first-order level nets of the United States and Canada, formerly called Sea Level Datum of 1929. 


\title{
HYDROGEOLOGY AND SIMULATED GROUND-WATER FLOW IN THE AREA OF GREENWICH TOWNSHIP, GLOUCESTER COUNTY, NEW JERSEY
}

\author{
By Amleto A. Pucci, Jr., Cynthia Barton, and Herbert T. Buxton
}

\begin{abstract}
The ground-water resources of the Potomac-Raritan-Magothy aquifer system and overlying upper Cenozoic deposits are the principal source of water supply in the area of Greenwich Township, Gloucester County, New Jersey. The aquifer system is composed of the surficial Cenozoic deposits and the upper, middle, and lower aquifers of the Potomac-RaritanMagothy aquifer system. The latter three aquifers are confined in the southeastern part of the study area, and are unconfined where they crop out in a band along the Delaware River.
\end{abstract}

Recent (1986) hydrologic conditions in the aquifer system were investigated by using a three-dimensional finite-difference ground-water-flow model. Flow in the unconfined part of the aquifer system is affected by discharge to small streams that traverse the outcrop area (some of which are controlled by tide gates) and pumping for decontamination, which result in a water table that is below sea level in areas of Greenwich Township and Paulsboro Borough. Measured and simulated water levels representative of recent (1986) conditions generally ranged from near sea level in the aquifer's outcrop areas along the Delaware River to as much as 70 feet below sea level in the southeastern part of the study area. The configuration of the potentiometric surfaces represents regional ground-water flow from recharge in the outcrop area to a large regional cone of depression centered southeast of the study area in Camden County.

The recent (1986) steady-state water budget calculated from results of model simulations indicates that the total ground-water flow in the study area is about 44.3 million gallons per day. The major source of inflow is recharge in the outcrop area ( 56 percent), followed by induced seepage from streams (27 percent), lateral flow (15 percent), and downward leakage from the Englishtown aquifer system (less than 2 percent). The major outflow from the study area is ground-water withdrawals ( 45 percent), followed by lateral flow (primarily to the southeast, 31 percent) and discharge to streams ( 24 percent). Results of model simulations indicate that induced seepage from small streams that cross the outcrop areas exceeds direct seepage from the mainstem of the Delaware River within the study area.

Additional sources of potable water from the unconfined part of the aquifer system ideally would tap (1) recharge in uncontaminated areas, (2) seepage from potable reaches of small streams, and (3) seepage from the Delaware River at times when or in places where the water quality is not affected by seawater. Factors affecting the selection of sites for additional withdrawals of potable water from the confined aquifers include (1) the decreased likelihood of contamination from human activities with distance downdip, (2) the progressive increase in drawdown in deeper aquifers, and (3) the possibility that saline ground water from the lower aquifer may encroach toward wells in the southern and southwestern parts of the study area. 


\section{INTRODUCTION}

The Greenwich Township area is located along the Delaware River and is characterized by mixed land uses with concentrations of large industrial complexes. Since World War II, development in the area has been the result of industrial growth in manufacture, refining, storage, and transport of petroleum products. Industrial development and population growth have occurred primarily near the mouths of the tributary streams to the Delaware River and, more recently, throughout the study area as a result of the completion of U.S. Highway 130 and Interstate 295 (Barton and Kozinski, 1991).

Most of the study area lies on or adjacent to the subcrop or outcrop of the PotomacRaritan-Magothy aquifer system in northwestern Gloucester County. The Potomac-RaritanMagothy aquifer system and the overlying upper Cenozoic deposits are the principal source of water supply in the Greenwich Township study area. Withdrawals from these units were nearly $20 \mathrm{Mgal} / \mathrm{d}$ in 1986 (Barton and Kozinski, 1991). Cones of depression have formed locally in the areas of these withdrawals. A large regional cone of depression has extended into the aquifers in the area from pumping northeast of the study area. Water levels have declined in one aquifer to an altitude of $68 \mathrm{ft}$ below sea level, and ground-water-flow patterns have been altered severely from those during predevelopment conditions. Industries that use hazardous chemicals that potentially could contaminate ground water, particularly in Greenwich Township and Paulsboro Borough, are located within the recharge area of the aquifer system. Most of the ground water in the PotomacRaritan-Magothy aquifer system in the study area is freshwater, but ground water in parts of the area is saline. The altered ground-water-flow system also has allowed the intrusion of saltwater from the Delaware River estuary and the migration of saline ground water from the southeastern part of the study area (Barksdale and others, 1958, p. 125, fig. 24; Hardt and Hilton, 1969, p. 1215 , figs. 4 and 5).

This report is the third of three reports that summarize the results of a comprehensive investigation of the ground-water resources in the Greenwich Township study area done during 1986-88 by the U.S. Geological Survey in cooperation with Greenwich Township and the New Jersey Department of Environmental Protection. The objectives of this investigation were to evaluate the effects of ground-water withdrawals, contamination from human activities, and saltwater intrusion on water supply in the study area. A three-phase approach was used to achieve these objectives. The results of each phase of the investigation are presented, respectively, in three reports, which (1) characterize the hydrogeologic framework of, and hydrologic conditions in, the Greenwich Township study area (Barton and Kozinski, 1991); (2) assess ground-water quality and geochemistry, and the extent of contamination from human activities (Barton and Kozinski, 1996); and (3) describe the ground-water-flow system under recent (1986) conditions by means of a ground-water-flow model (this report).

\section{Purpose and Scope}

This report describes a quantitative analysis of the ground-water system in the Greenwich Township area, including the development and application of a ground-water-flow model. It reports (1) a conceptual hydrogeologic model of the ground-water-flow system under predeveloped and developed conditions, and (2) results of simulating the ground-water-flow system under recent (1986) developed conditions. The report includes maps that show the hydrogeologic framework and the distribution of the transmissivity of aquifers and leakance properties of confining units, and describes ground-water-flow patterns and the interaction between groundwater and surface-water systems. The report also defines the ground-water budget under developed conditions. The hydrogeologic data used to construct the ground-water-flow model were collected as part of the initial phase of the study, and include data on aquifer and confining- 
unit characteristics, and withdrawals and water levels in 1986. These data, as well as a description of the hydrogeologic units in the study area, are presented in Barton and Kozinski (1991).

\section{Description of the Study Area}

The study area comprises approximately $115 \mathrm{mi}^{2}$ in and near Greenwich Township, Gloucester County, New Jersey (fig. 1). The region also includes the City of Chester and Tinicum Township, on the northwestern bank of the Delaware River in southern Delaware and Philadelphia Counties, Pennsylvania. Two major physiographic provinces are located in or near the study area (Fenneman, 1938). The unconsolidated sediments of the Atlantic Coastal Plain physiographic province that characterize most of the study area comprise a southeastward-dipping, seaward-thickening wedge that pinches out to the northwest at the Fall Line (fig. 1). The Fall Line generally separates the Atlantic Coastal Plain from the Piedmont physiographic province. The Piedmont, which is located in the northwestern part of the study area in Pennsylvania, is characterized by Precambrian and lower Paleozoic metamorphic and igneous rocks that are overlain by a thin mantle of regolith. The land surface slopes gently to the northwest toward the Delaware River. Land-surface elevation ranges from sea level near the Delaware River to $140 \mathrm{ft}$ above sea level in the southeastern part of the study area. Areas less than $5 \mathrm{ft}$ above sea level generally are covered by tidal-marsh deposits and vegetation; in Greenwich Township, however, tidal flooding is limited by dikes and floodgates. An area of about $2.7 \mathrm{mi}^{2}$ in the Repaupo Creek drainage basin in the central part of the region is maintained below sea level by tide gates (fig. 2). Most surface-water drainage is tidal and flows to the northwest.

\section{Previous Investigations}

Numerous studies of the ground-water resources of the Potomac-Raritan-Magothy aquifer system have included, or were done in areas adjacent to, the Greenwich Township region. These include investigations conducted in the lower Delaware River valley (Barksdale and others, 1958); the Coastal Plain of southeastern Pennsylvania (Greenman and others, 1961); the Delaware River Basin (Parker and others, 1964); Gloucester County (Hardt and Hilton, 1969); Salem County (Rosenau and others, 1969); Camden County and vicinity (Farlekas and others, 1976; Navoy and Carleton, 1995); Logan Township (Andres, 1984; Kozinski and others, 1990; Lewis and others, 1991); Philadelphia, Pennsylvania (Sloto, 1986); Delaware County, Pennsylvania (Balmer and Davis, 1993); and the Coastal Plain of New Jersey (Richards and others, 1962; Gill and Farlekas, 1976; Luzier, 1980; Harbaugh and others, 1980; Zapecza, 1989; Martin, in press).

Geologic studies in southern New Jersey and the northern Delmarva Peninsula include descriptions of the stratigraphy of post-Magothy Formation Upper Cretaceous (Owens and others, 1970) and upper Cenozoic sediments (Owens and Minard, 1979). Evaluations of water levels in the aquifers of the region include maps of the water table in Philadelphia, Pennsylvania (Paulachok and Wood, 1984), and in southern Gloucester County, New Jersey (Lacombe and Rosman, 1995); maps of the potentiometric surfaces of the major aquifers of the New Jersey Coastal Plain in 1983 (Eckel and Walker, 1986); and maps of the Potomac-Raritan-Magothy aquifer system in the Greenwich Township study area (Barton and Kozinski, 1991).

\section{Acknowledgments}

The authors thank the New Jersey Department of Environmental Protection for supplying withdrawal and well data. Thanks also are given to the municipalities, industries, and individuals who provided withdrawal and well information to the U.S. Geological Survey. 


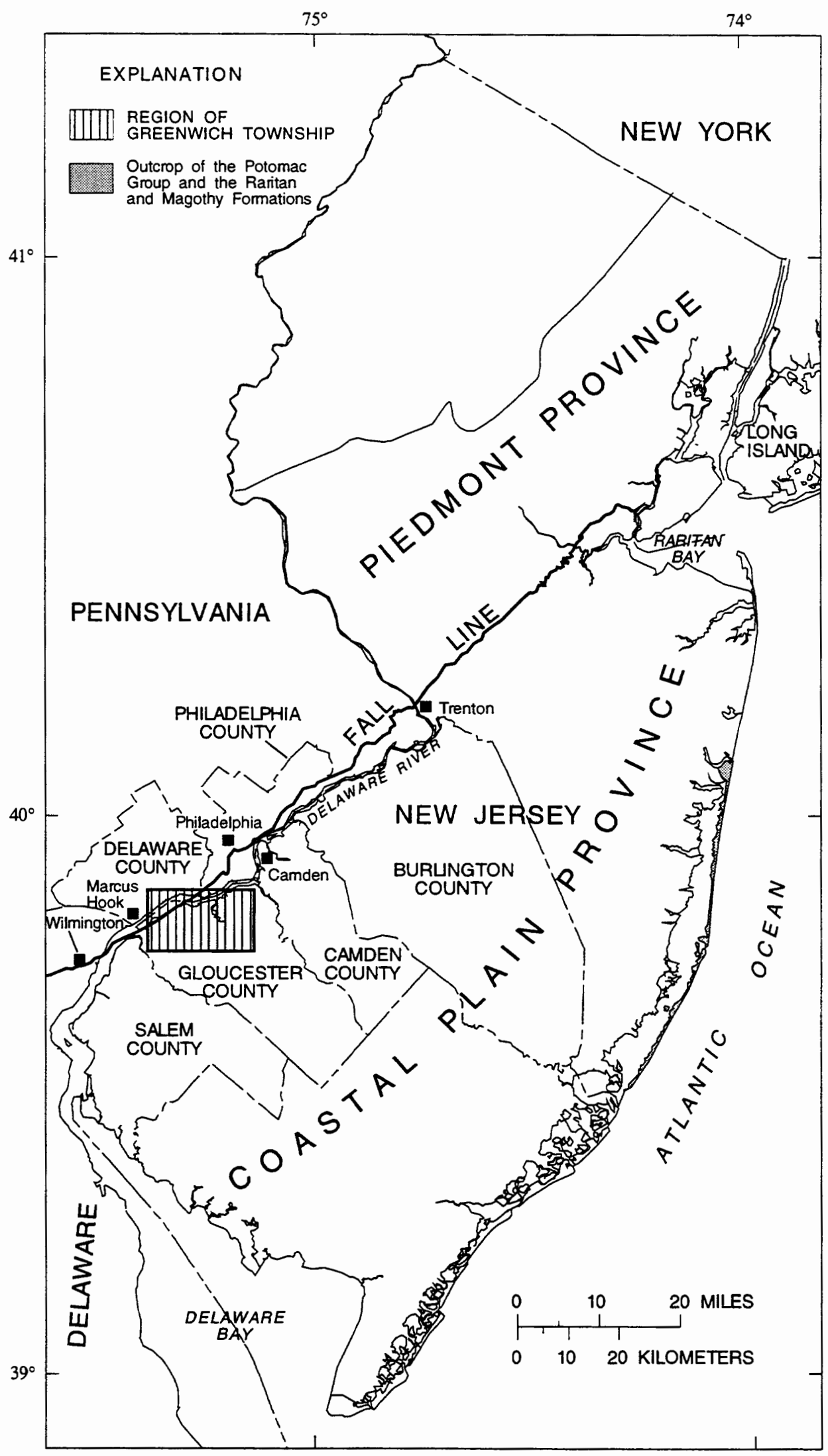

Figure 1. Location of the study area and physiographic provinces. (From Barton and Kozinski, 1991) 


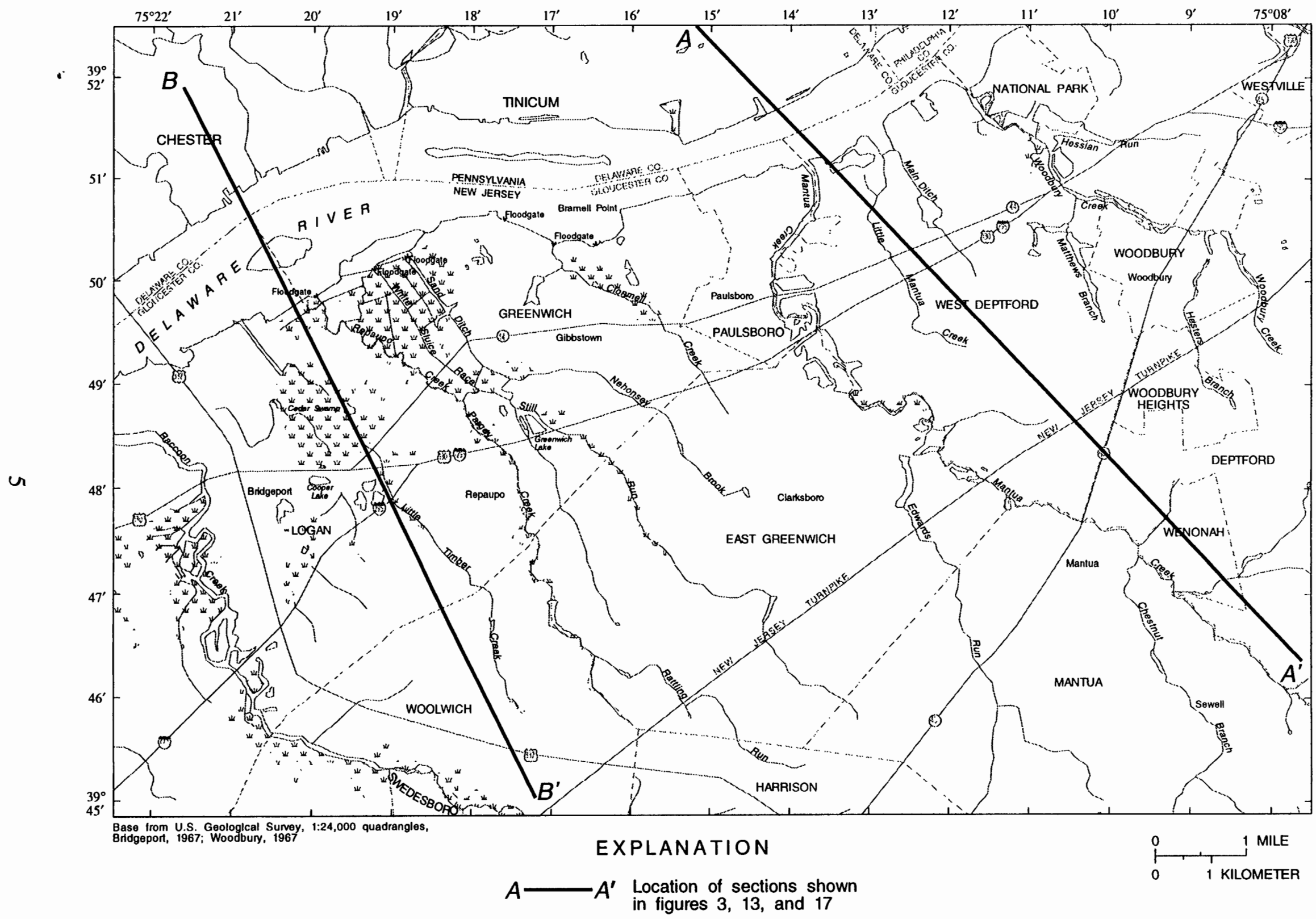

Figure 2. The Greenwich Township, New Jersey, study area. (Location shown in figure 1) 


\section{HYDROGEOLOGY}

The hydrologic cycle describes a continuous circulation of water among the atmosphere, the land surface, the soil zone, and the sediments that comprise the ground-water system. This circulation occurs through the processes of condensation, precipitation, evaporation, transpiration, infiltration, and runoff. Atmospheric precipitation falls on the earth's surface and either becomes surface runoff, is transpired by plants, evaporates, or recharges the ground-water system at the water table.

The ground-water system is a body of saturated sediments in which water is continually moving. It is bounded by contacts with natural hydrologic features that limit flow and control recharge to and discharge from the system. The distribution of flow is defined by the hydrogeologic properties of the aquifer system, which include the geometry of aquifers and confining units and the distribution of water-transmitting properties within the system. The hydrogeologic framework, the hydrologic boundaries, and the behavior of the ground-water-flow system in the study area (the conceptual hydrogeologic model) under predeveloped and developed conditions are described qualitatively in the following sections.

\section{Hydrogeologic Units}

Coastal Plain sediments form a wedge-shaped mass deposited on Paleozoic and Precambrian bedrock. The sediments consist of alternating layers of sand, silt, and clay that strike northeast and dip toward the southeast in the study area (fig. 3). The thickness of the deposits in the study area ranges from a featheredge along the Fall Line to more than $900 \mathrm{ft}$ in southeastern Gloucester County.

The hydrogeologic framework of the Greenwich Township study area is depicted in a series of maps and sections that define the geometry of the aquifers and confining units that comprise the physical framework of the ground-water-flow system. Aquifer units have watertransmitting properties such that they freely yield water to wells and act as conduits for the flow of water within the system. Confining units typically are much less permeable than aquifers (by several orders of magnitude), but transmit water vertically between aquifers. Figure 3 shows generalized sections through the various hydrogeologic units in the region. Table 1 is a stratigraphic column that can be used to relate geologic strata to the corresponding hydrogeologic units. Figures 4 through 12 show structure contours of hydrogeologic units in the study area.

The oldest Coastal Plain sediments are of the Potomac Group and Raritan and Magothy Formations of Cretaceous age, which make up the aquifers and confining units of the PotomacRaritan-Magothy aquifer system (fig. 3 and table 1). In the New Jersey Coastal Plain, this aquifer system generally is divided into the lower, middle, and upper aquifers, which are separated from each other by confining units (fig. 3) (Zapecza, 1989, p. 14). In the Greenwich Township study area, a discontinuous confining unit locally divides the updip part of the middle aquifer into two distinct hydrogeologic units (Barton and Kozinski, 1991).

The altitude of the top of the bedrock surface beneath the Potomac-Raritan-Magothy aquifer system is shown in figure 4. In the Greenwich Township study area, the bedrock consists of lower Paleozoic and Precambrian metamorphic and igneous rocks overlain by a gradational zone of weathered bedrock (Zapecza, 1989, table 1). In general, the bedrock surface dips at a rate of about 60 to $100 \mathrm{ft} / \mathrm{mi}$ (Barton and Kozinski, 1991). The bedrock is significantly less permeable than the overlying unconsolidated sediments. 


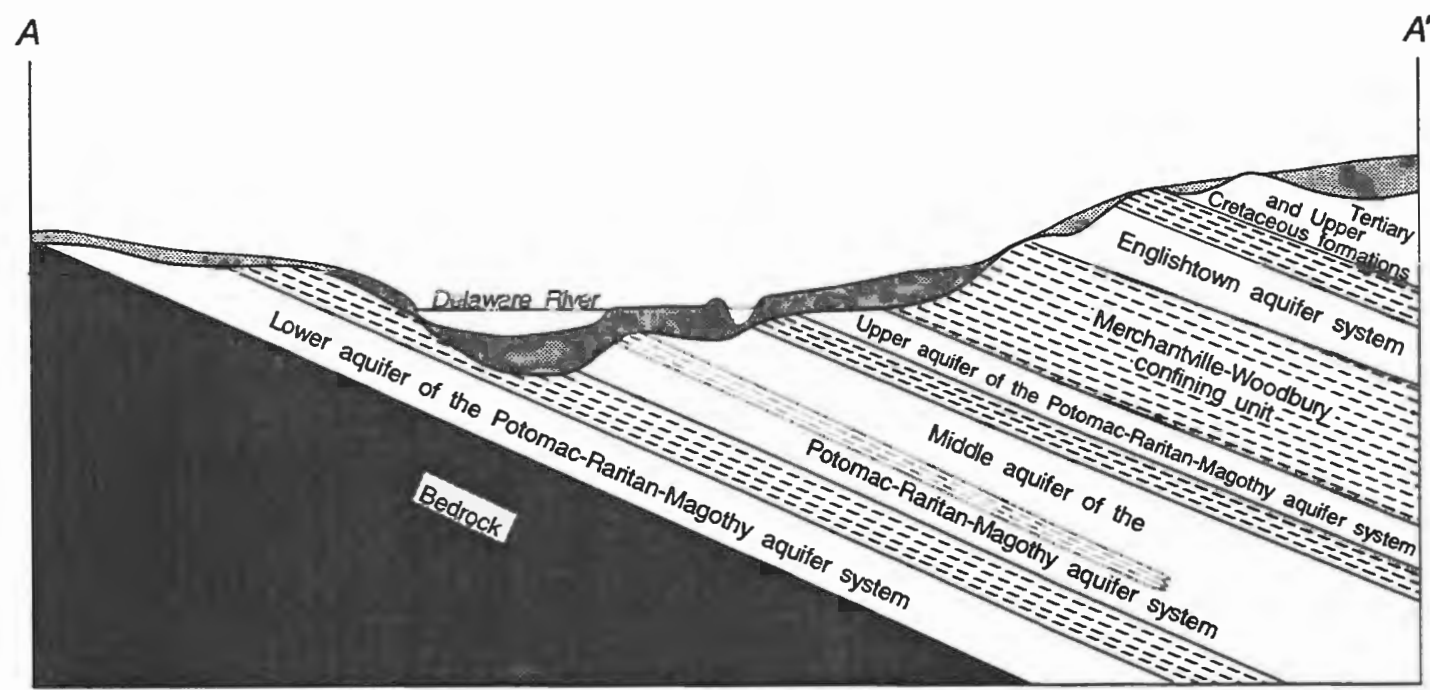

NOT TO SCALE

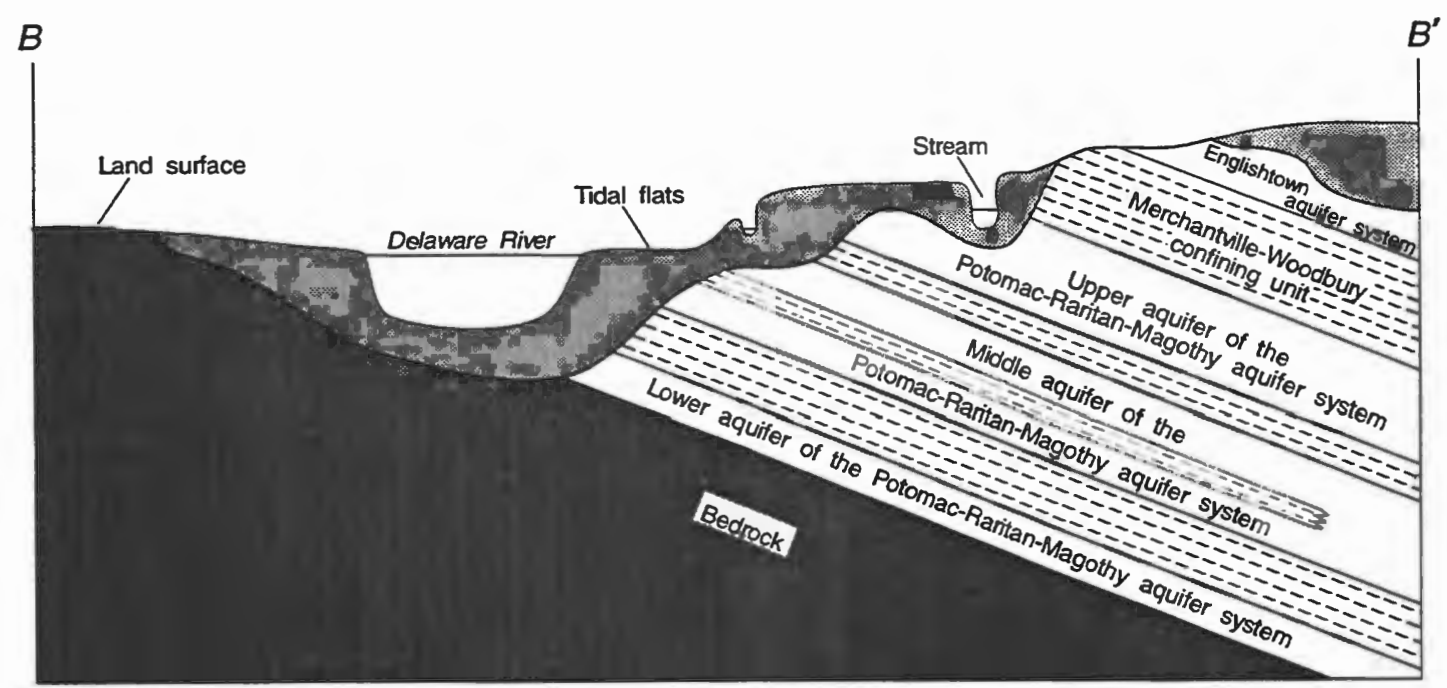

NOT TO SCALE

EXPLANATION

$E=-7$ Confining unit

1. Upper Cenozoic deposits

Figure 3. Generalized hydrogeologic sections through the major hydrogeologic units in the Greenwich Township, New Jersey, study area. (Location of sections shown in fig. 2) 
Table 1. Geologic and hydrogeologic units in the area of Greenwich Township, Gloucester County, New Jersey

[From Barton and Kozinski (1991, table 1)]

\begin{tabular}{|c|c|c|c|c|c|c|}
\hline Era & System & Series & & Geologic unit & \multicolumn{2}{|c|}{ Hydrogeologic unit } \\
\hline \multirow{7}{*}{ Cenozoic } & \multirow{3}{*}{ Quaternary } & Holocene & \multirow{3}{*}{ 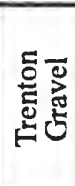 } & Alluvial deposits & \multirow{5}{*}{\multicolumn{2}{|c|}{$\begin{array}{l}\text { Surficial material, commonly } \\
\text { hydraulically connected to underly } \\
\text { ing aquifers. Locally some units } \\
\text { may act as confining units. Thick } \\
\text { sands are capable of yielding large } \\
\text { quantities of water. }\end{array}$}} \\
\hline & & \multirow{2}{*}{ Pleistocene } & & Van Sciver Lake beds & & \\
\hline & & & & Spring Lake beds & & \\
\hline & \multirow{4}{*}{ Tertiary } & \multirow{2}{*}{ Miocene } & \multicolumn{2}{|c|}{ Pensauken Formation } & & \\
\hline & & & \multicolumn{2}{|c|}{ Bridgeton Formation } & & \\
\hline & & Eocene & \multirow{3}{*}{\multicolumn{2}{|c|}{$\begin{array}{l}\text { Other geologic units are found } \\
\text { in the southeastern corner of } \\
\text { the region but are not discussed } \\
\text { in this report. See Zapecza } \\
\text { (1989) for detailed discussion } \\
\text { of these units. }\end{array}$}} & \multirow{3}{*}{\multicolumn{2}{|c|}{$\begin{array}{l}\text { Hydrogeologic units not discussed } \\
\text { in this report. }\end{array}$}} \\
\hline & & Paleocene & & & & \\
\hline \multirow{9}{*}{ Mesozoic } & \multirow{9}{*}{ Cretaceous } & \multirow{8}{*}{ Upper Cretaceous } & & & & \\
\hline & & & Engli & shtown Formation & Englishto & n aquifer system \\
\hline & & & Wood & bury Clay & \multirow{2}{*}{\multicolumn{2}{|c|}{$\begin{array}{l}\text { Merchantville-Woodbury } \\
\text { confining unit }\end{array}$}} \\
\hline & & & \multicolumn{2}{|c|}{ Merchantville Formation } & & \\
\hline & & & \multicolumn{2}{|c|}{ Magothy Formation } & \multirow{5}{*}{ 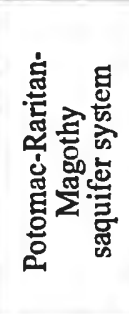 } & Upper aquifer \\
\hline & & & \multirow{4}{*}{\multicolumn{2}{|c|}{$\begin{array}{l}\text { Raritan Formation }{ }^{1} \\
\text { Potomac Group }\end{array}$}} & & Confining unit \\
\hline & & & & & & Middle aquifer ${ }^{2}$ \\
\hline & & & & & & Confining unit \\
\hline & & Lower Cretaceous & & & & Lower aquifer \\
\hline $\begin{array}{l}\text { Paleozoic and } \\
\text { Precambrian }\end{array}$ & \multicolumn{2}{|c|}{ Pre-Cretaceous } & \multicolumn{2}{|r|}{ Wissahickon Formation } & \multicolumn{2}{|c|}{ Bedrock confining unit } \\
\hline
\end{tabular}

${ }^{1}$ Raritan Formation may be absent in southern New Jersey (Owens and others, 1970, fig. 5, p. 9).

${ }^{2}$ A discontinuous confining unit locally divides the middle aquifer into two distinct aquifer units. 


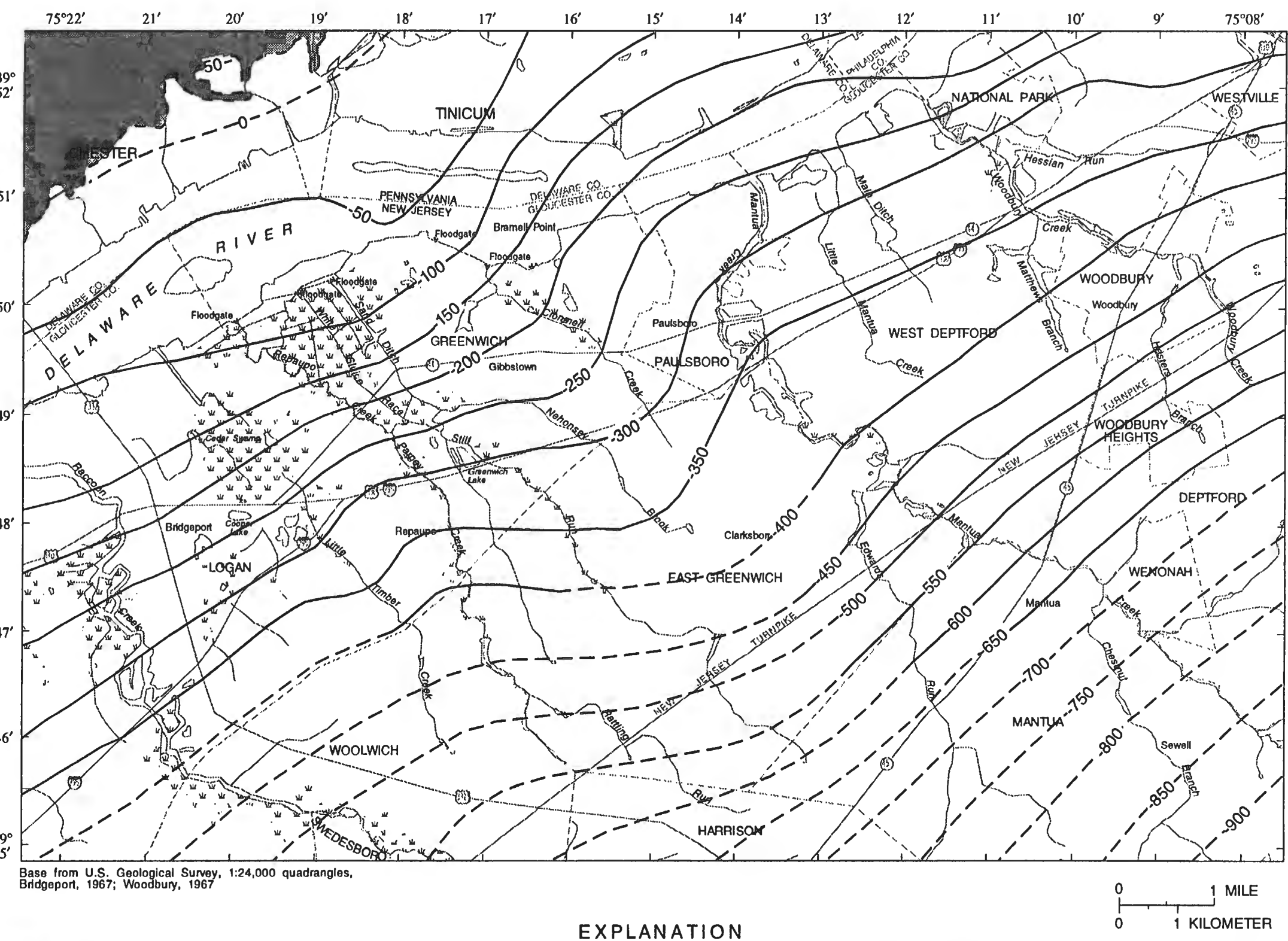

SUBCROP OR OUTCROP OF LOWER PALEOZOIC AND PRECAMBRIAN METAMORPHIC AND IGNEOUS ROCKS (BEDROCK) OF WISSAHICKON FORMATION-Contact is dashed where extent is approximate

$100--$ STRUCTURE CONTOUR--Shows altitude of the top surface of the
lower Palaozoic and Precambrian metamorphic and igneous rocks
(bedrock). Contour is dashed where inferred. Contour interval 50 foet. Datum is sea level

Figure 4. Altitude of the top of the bedrock surface in the Greenwich Township, New Jersey, study area. (Modified from Barton and Kozinski, 1991, pl. 7b) 
The altitude of the top of the lower aquifer of the Potomac-Raritan-Magothy aquifer system is shown in figure 5 . This aquifer consists primarily of sand with interbedded gravel and lignitic silt and clay deposits that are mapped as undivided Raritan Formation and Potomac Group. The top surface generally slopes to the southeast at 40 to $110 \mathrm{ft} / \mathrm{mi}$. The thickness of the lower aquifer averages about $100 \mathrm{ft}$, reaches a maximum of more than $340 \mathrm{ft}$, and generally increases toward the southeast. The lower aquifer of the Potomac-Raritan-Magothy aquifer system overlies weathered bedrock throughout the Greenwich Township region (Barton and Kozinski, 1991).

The altitude of the top of the confining unit between the middle and lower aquifers is shown in figure 6. This confining unit consists of clay and silt deposits mapped as undivided Raritan Formation and Potomac Group (Owens and others, 1970, p. 9, fig. 5). The top surface of the confining unit dips southeastward at 50 to $100 \mathrm{ft} / \mathrm{mi}$. The unit generally thickens to the south. The thickness of the confining unit averages $45 \mathrm{ft}$ and has a maximum of $101 \mathrm{ft}$ (Barton and Kozinski, 1991).

Locally the middle aquifer is separated into two distinct aquifers by a discontinuous confining unit. The altitude of the top of the lower part of the middle aquifer is shown in figure 7. This unit consists primarily of medium- to coarse-grained sand and gravel with interbedded silt and clay of the undivided Raritan Formation and Potomac Group. Its upper extent is the base of the confining unit dividing the middle aquifer. Where the confining unit is present, the thickness of the lower part of the middle aquifer in the Greenwich Township region averages $36 \mathrm{ft}$ and has a maximum thickness of about $100 \mathrm{ft}$ (Barton and Kozinski, 1991).

The altitude of the top of the confining unit dividing the middle aquifer is shown in figure 8. This confining unit consists predominantly of discontinuous clay deposits mapped as undivided Raritan Formation and Potomac Group (Owens and others, 1970, p. 9) and Cenozoic sediments near Raccoon Island in Logan Township, and Tinicum Township in Pennsylvania. The surface of the unit slopes uniformly southeastward at about $60 \mathrm{ft} / \mathrm{mi}$. Its thickness averages $20 \mathrm{ft}$ and attains a maximum of more than $60 \mathrm{ft}$ in northwestern West Deptford Township. The unit is absent and probably was eroded and replaced by upper Cenozoic sand and gravel deposits beneath the Delaware River and adjacent to the river in Paulsboro Borough and in Greenwich and West Deptford Townships (Barton and Kozinski, 1991).

The altitude of the top of the upper part of the middle aquifer is shown in figure 9. In the study area, the subcrop of the upper part of the middle aquifer lies mostly within New Jersey and adjacent to and beneath the Delaware River. The middle aquifer consists predominantly of medium- to coarse-grained sand and gravel with interbedded silt and clay of the undivided Raritan Formation and Potomac Group. Beneath the Delaware River and in northeastern Greenwich Township and Paulsboro Borough, the middle aquifer probably has been eroded and replaced by upper Cenozoic sand and gravel. Adjacent to Raccoon Creek in Logan Township and Repaupo Creek in Greenwich Township, it probably has been replaced by fine-grained upper Cenozoic deposits (Barton and Kozinski, 1991). The thickness of the middle aquifer averages 87 $\mathrm{ft}$ and attains a maximum of more than $160 \mathrm{ft}$ in southern Greenwich Township and in Woodbury Heights.

The altitude of the top of the confining unit between the upper and middle aquifers is shown in figure 10. The unit is composed of silty clay with interbedded silt and sand of the undivided Raritan Formation and Potomac Group (table 1). The top surface of this confining unit generally slopes southeastward at about $40 \mathrm{ft} / \mathrm{mi}$. The unit generally thickens towards the south to a maximum of about $90 \mathrm{ft}$ but in many areas is thinner than $20 \mathrm{ft}$. The confining unit is absent and probably was eroded and replaced by upper Cenozoic sand and gravel in Paulsboro Borough and Greenwich and northwestern West Deptford Townships (Barton and Kozinski, 1991). 


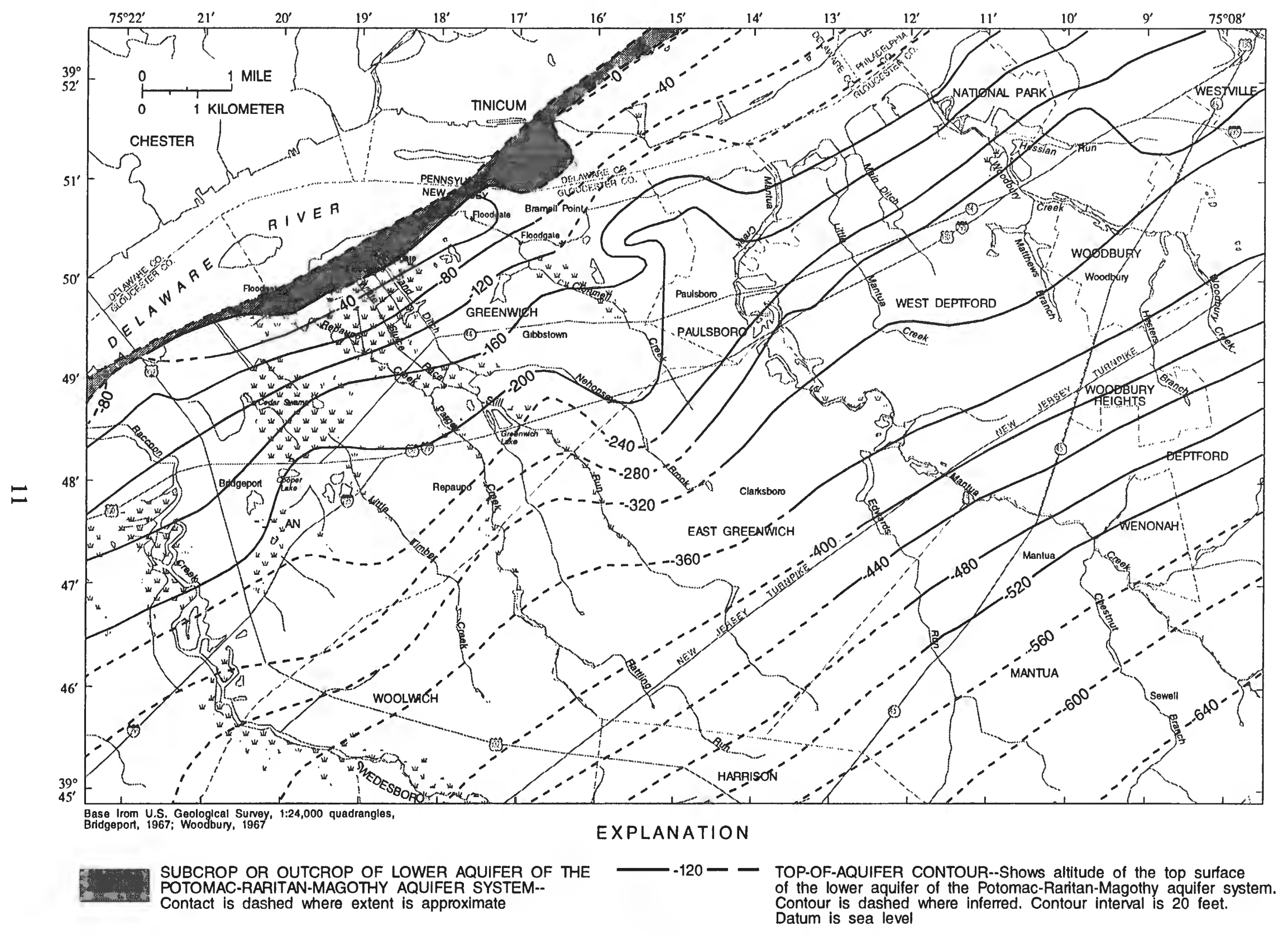

Figure 5. Altitude of the top of the lower aquifer of the Potomac-Raritan-Magothy aquifer system in the Greenwich Township, New Jersey, study area. (Modified from Barton and Kozinski, 1991, pl. 7a) 


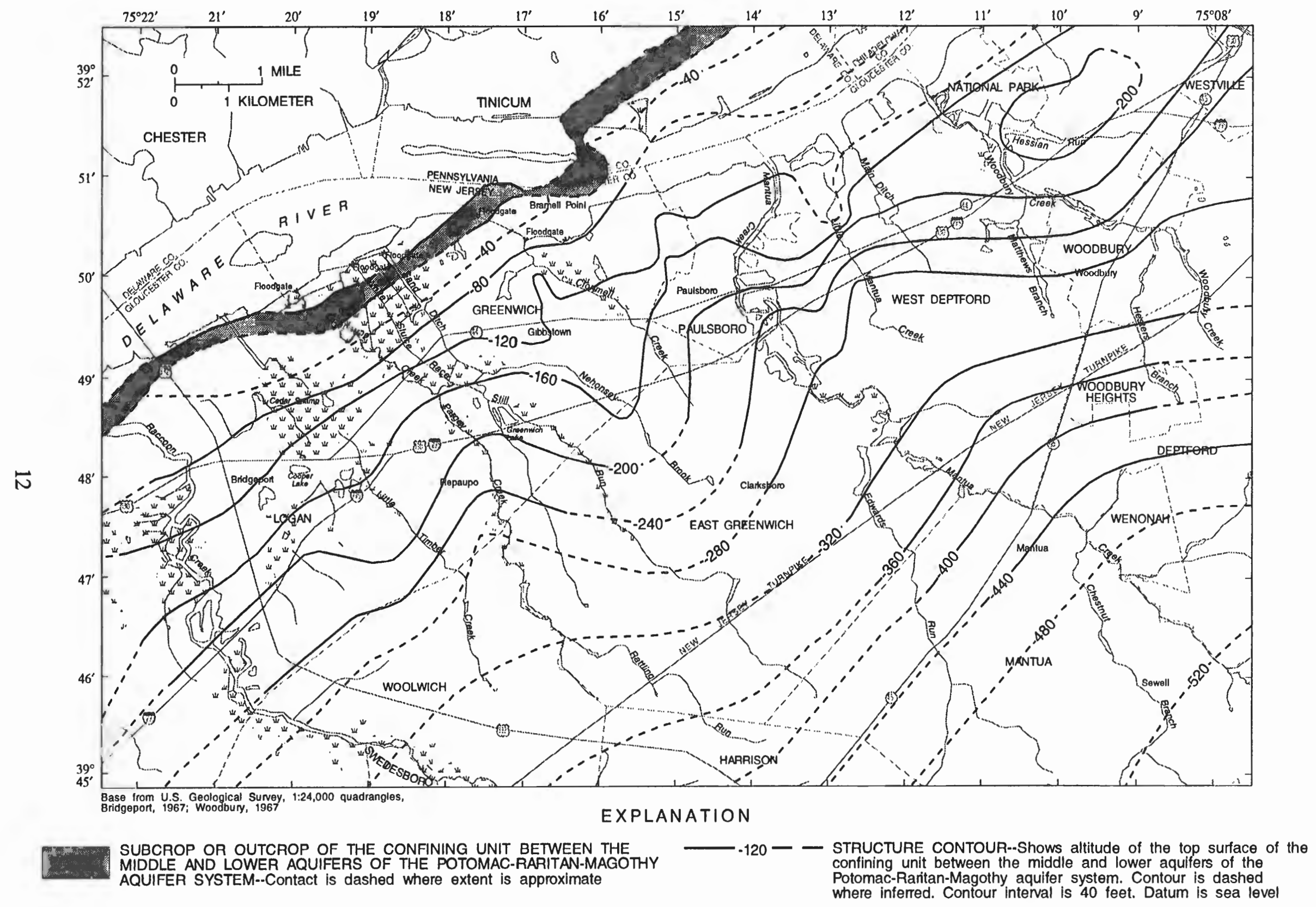

Figure 6. Altitude of the top of the confining unit between the middle and lower aquifers of the Potomac-Raritan-Magothy aquifer system in the Greenwich Township, New Jersey, study area. (Modified from Barton and Kozinski, 1991, pl. 6b) 


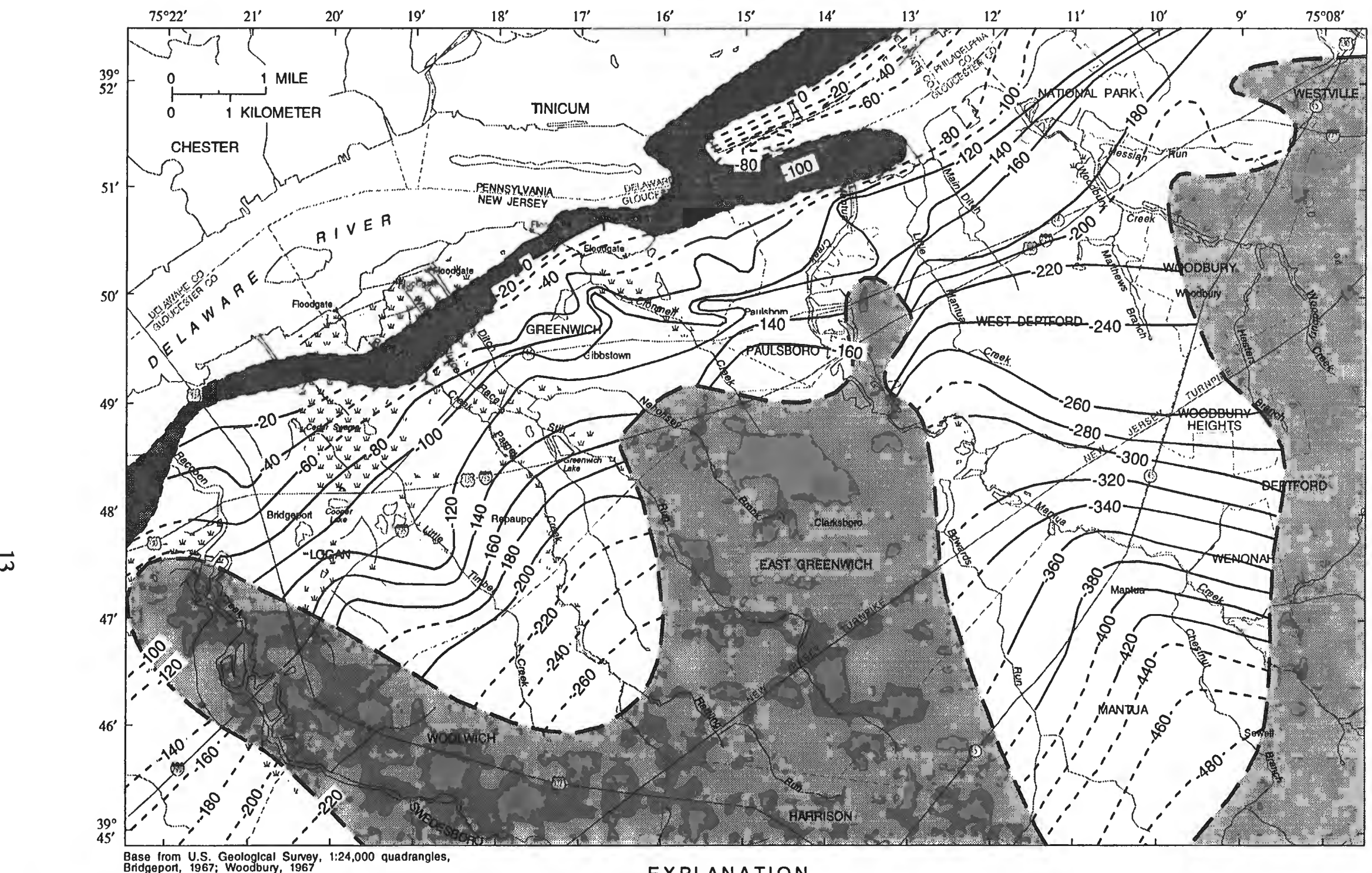

Base from U.S. Geologlcal Suney, 1:24,000 quadrangles,
Bridgeport, 1967; Woodbury, 1967

\section{EXPLANATION}

SUBCROP OR OUTCROP OF LOWER PART OF THE MIDDLE AQUIFER OF THE POTOMAC-RARITAN-MAGOTHY AQUIFER SYSTEM--Contact is dashed where extent is approximate

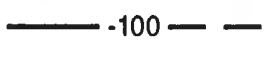

APPROXIMATE EXTENT OF AREA IN WHICH THE UPPER AND LOWER PARTS OF THE MIDDLE AQUIFER OF THE POTOMAC-RARITAN-

MAGOTHY AQUUIFER SYSTEM CANNOT BE DIFFERENTIATED

Figure 7. Altitude of the top of the lower part of the middle aquifer of the Potomac-Raritan-Magothy aquifer system in the Greenwich Township, New Jersey, study area. (Modified from Barton and Kozinski, 1991, pl. 6a) 


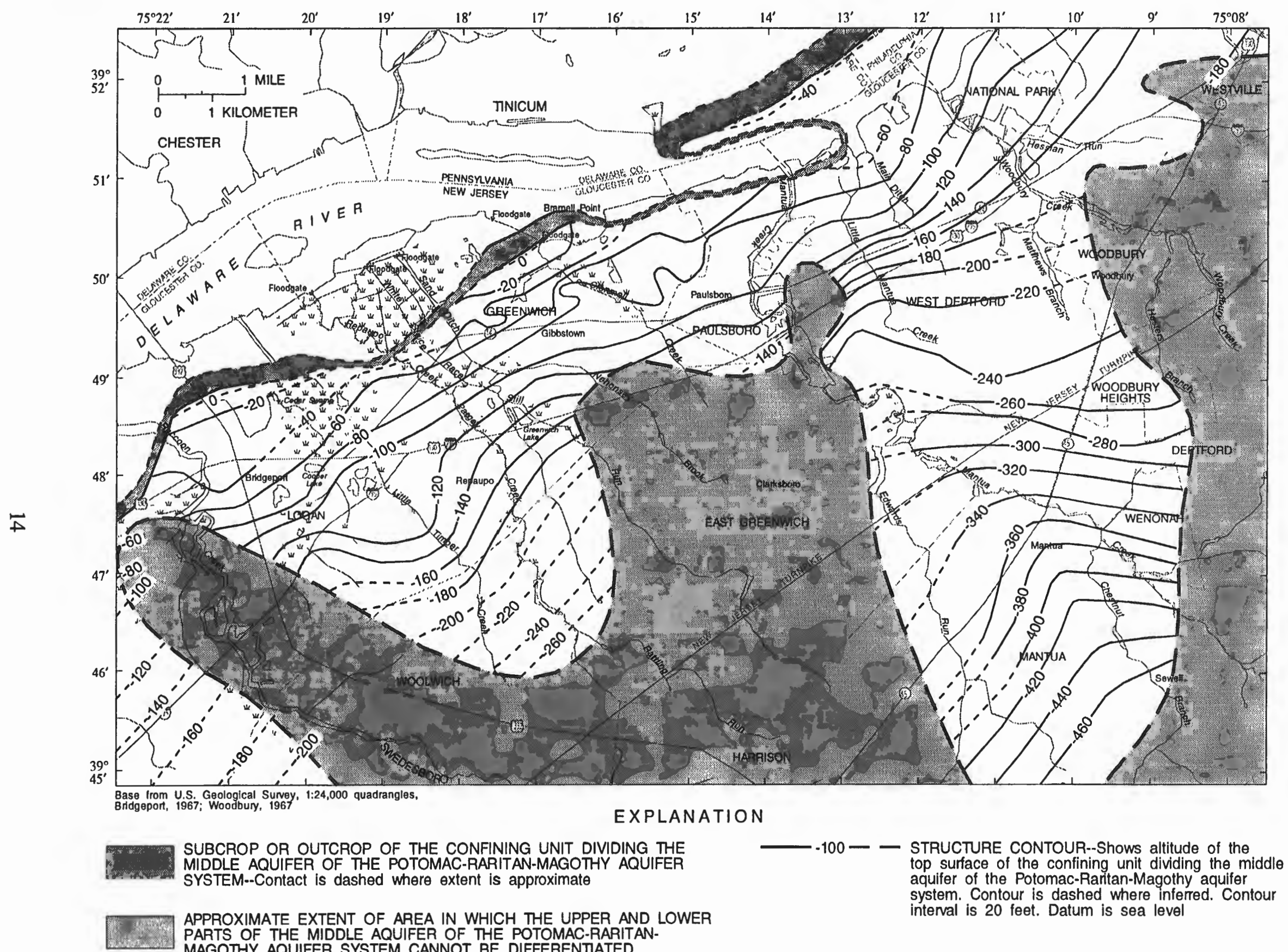
PARTS OF THE MIDDLE AQUIFER OF THE POTOMAC-RAPITAN-

Figure 8. Altitude of the top of the confining unit dividing the middle aquifer of the Potomac-Raritan-Magothy aquifer system in the Greenwich Township, New Jersey, study area. (Modified from Barton and Kozinski, 1991, pl. 5b) 


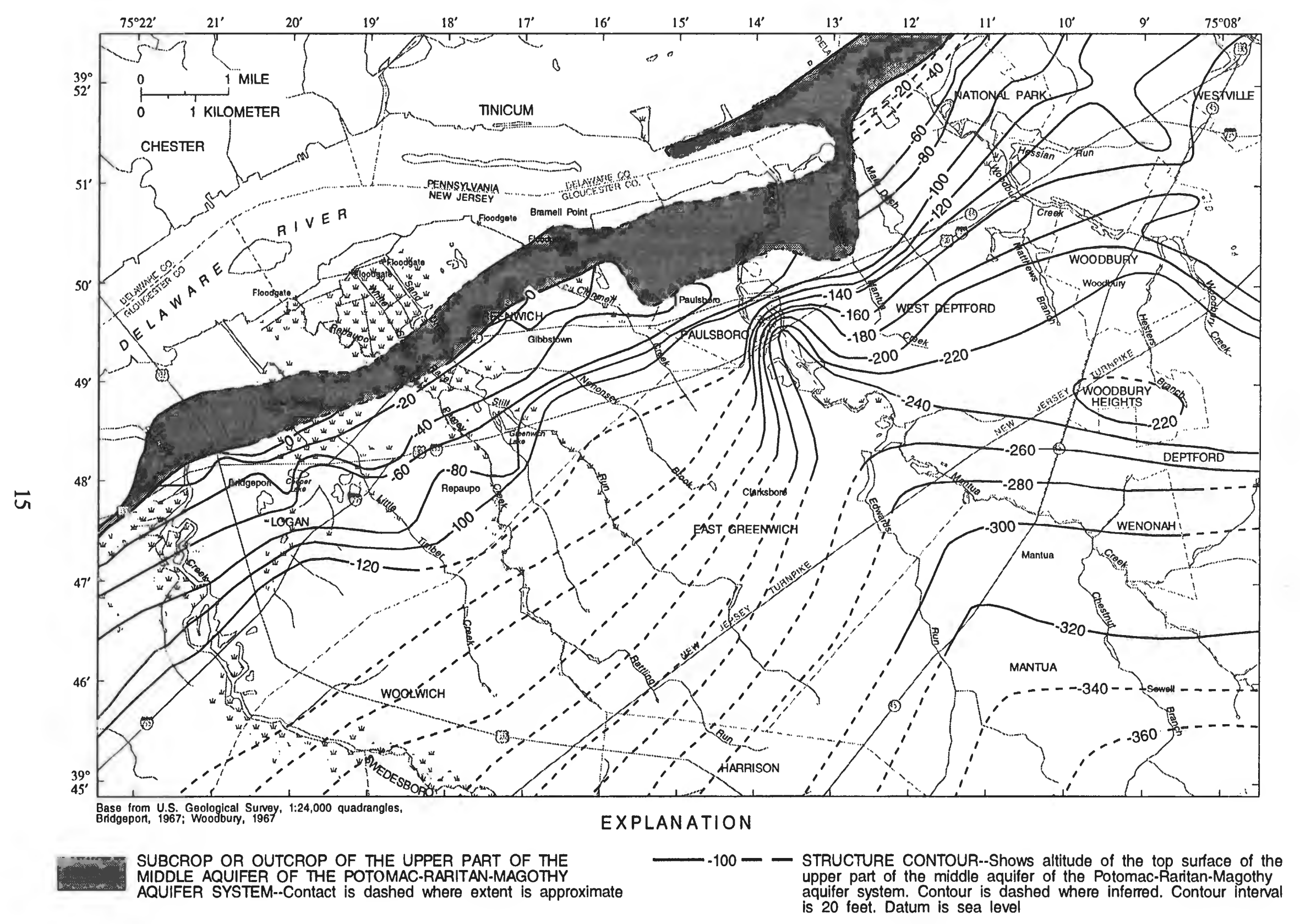

Figure 9. Altitude of the top of the upper part of the middle aquifer of the Potomac-Raritan-Magothy aquifer system in the Greenwich Township, New Jersey, study area. (Modified from Barton and Kozinski, 1991, pl. 5a) 


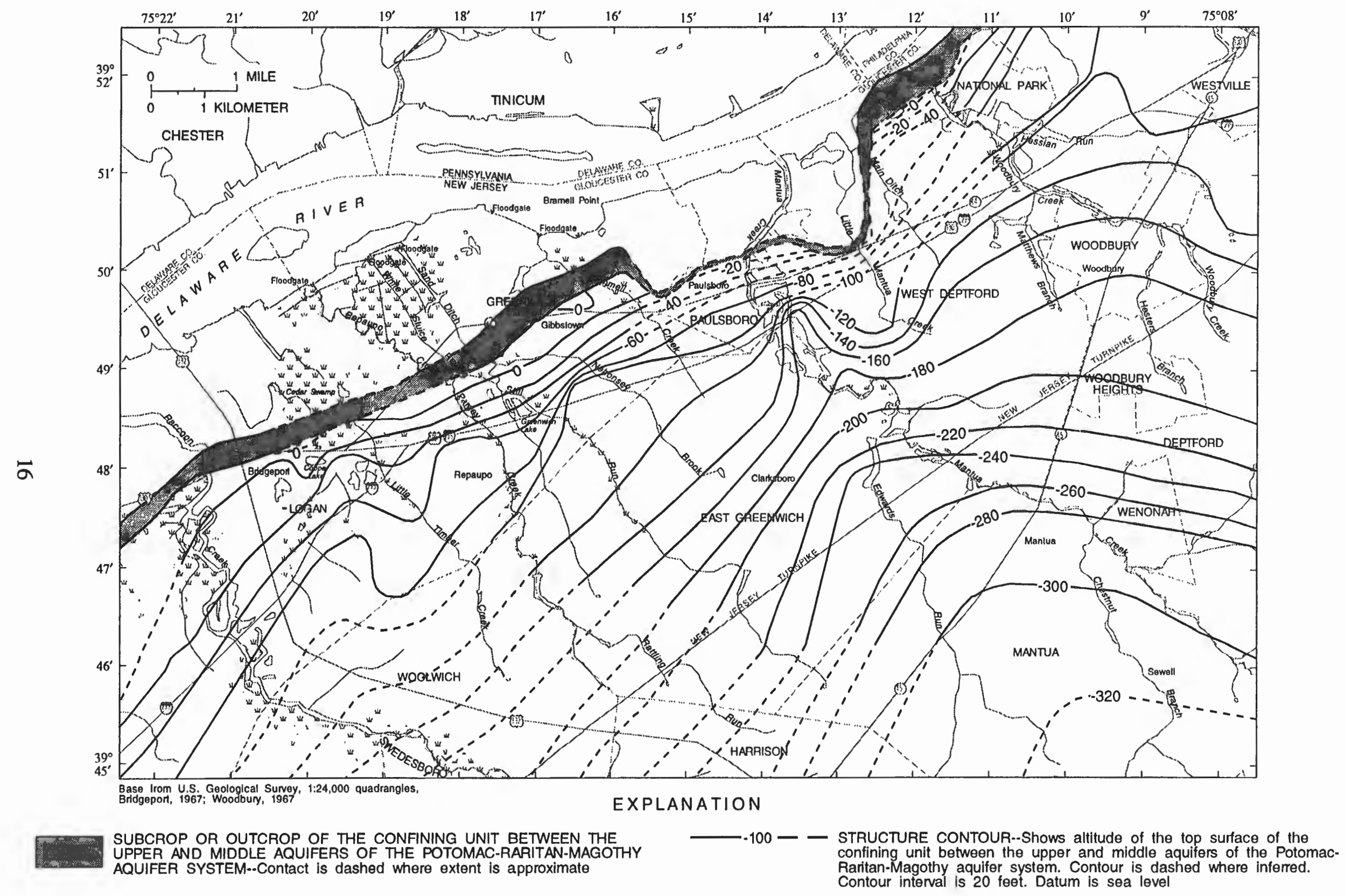

Figure 10. Altitude of the top of the confining unit between the upper and middle aquifers of the Potomac-Raritan-Magothy aquifer system in the Greenwich Township, New Jersey, study area. (Modified from Barton and Kozinski, 1991, pl. 4b) 
The altitude of the top of the upper aquifer is shown in figure 11. The upper aquifer is the uppermost unit of the Potomac-Raritan-Magothy aquifer system and consists predominantly of sands, gravels, and silty clay of the Magothy Formation (Zapecza, 1989, p. 11). The upper aquifer has an average thickness of $72 \mathrm{ft}$ in the study area, generally thickens to the southeast, and reaches a maximum thickness of about $164 \mathrm{ft}$ near Clarksboro. The upper aquifer probably has been eroded and replaced by upper Cenozoic sand and gravel deposits in Paulsboro Borough, Greenwich Township, and northwestern West Deptford Township (Barton and Kozinski, 1991).

The altitude of the top of the Merchantville-Woodbury confining unit are shown in figure 12. The unit overlies the Potomac-Raritan-Magothy aquifer system in the southeastern part of the Greenwich Township study area. This confining unit consists of the Woodbury Clay and thick interbedded clay, silt, and sand of the Merchantville Formation (table 1); the combined thickness of this unit averages about $100 \mathrm{ft}$ and reaches a maximum of about $160 \mathrm{ft}$ in southeastern Mantua Township.

The Englishtown aquifer system, which is found in the southeastern part of the Greenwich Township study area, overlies and is separated from the Potomac-Raritan-Magothy aquifer system by the Merchantville-Woodbury confining unit. In the study area, the Englishtown aquifer system generally is composed of less than $40 \mathrm{ft}$ of fine- to coarse-grained quartzose sand containing local lenses of clay; it dips to the southeast at about $40 \mathrm{ft} / \mathrm{mi}$ (Barksdale and others, 1958 , p. 137).

The outcrop of this sequence of hydrogeologic units was eroded and subsequently overlain by upper Cenozoic sediments. These surficial sediments generally are composed of fineto coarse-grained sand with extensive gravel lenses that generally are less than $30 \mathrm{ft}$ thick. These sediments are fluvial in origin and contain reworked sediments from the underlying Cretaceousage sediments (table 1) (Zapecza, 1989). Barton and Kozinski (1991) report that the Cenozoic deposits are as much as $100 \mathrm{ft}$ thick in areas where they have replaced eroded Cretaceous deposits in northern Paulsboro Borough, in northeastern Greenwich Township, in northwestern West Deptford Township, and probably near Raccoon Creek.

Sediments beneath the Delaware River channel and tidal wetlands within the region are composed of Holocene and upper Pleistocene alluvial deposits of clay, silt, and sand overlying the Cretaceous sediments and bedrock (Duran, 1986). At the western end of the study area, the Cretaceous sediments terminate south of the river, so that the Holocene and upper Pleistocene sediments directly overlie the bedrock under the riverbed (fig. 3). Some channel deposits may retard the seepage of Delaware River water into the Potomac-Raritan-Magothy aquifer system; however, continued channel dredging to a depth of at least $40 \mathrm{ft}$ below sea level allows river water to flow into the aquifer system (Barton and Kozinski, 1991).

\section{Ground-Water Flow}

The ground-water-flow system in the area of Greenwich Township is bounded by natural hydrologic boundaries on its top, bottom, and updip-lateral extents. The system is bounded above by the water table and small streams that drain to the Delaware River. The system is bounded below by its contact with consolidated bedrock, which is significantly less permeable than the unconsolidated sediments of the Potomac-Raritan-Magothy aquifer system. Laterally, the system is bounded to the northwest (updip) by the Delaware River or bedrock. To the south and east the ground-water-flow system extends laterally well beyond the study area. The Potomac-RaritanMagothy aquifer system is a regional ground-water-flow system that extends throughout southern New Jersey. The study area is only a small part of that flow system. 


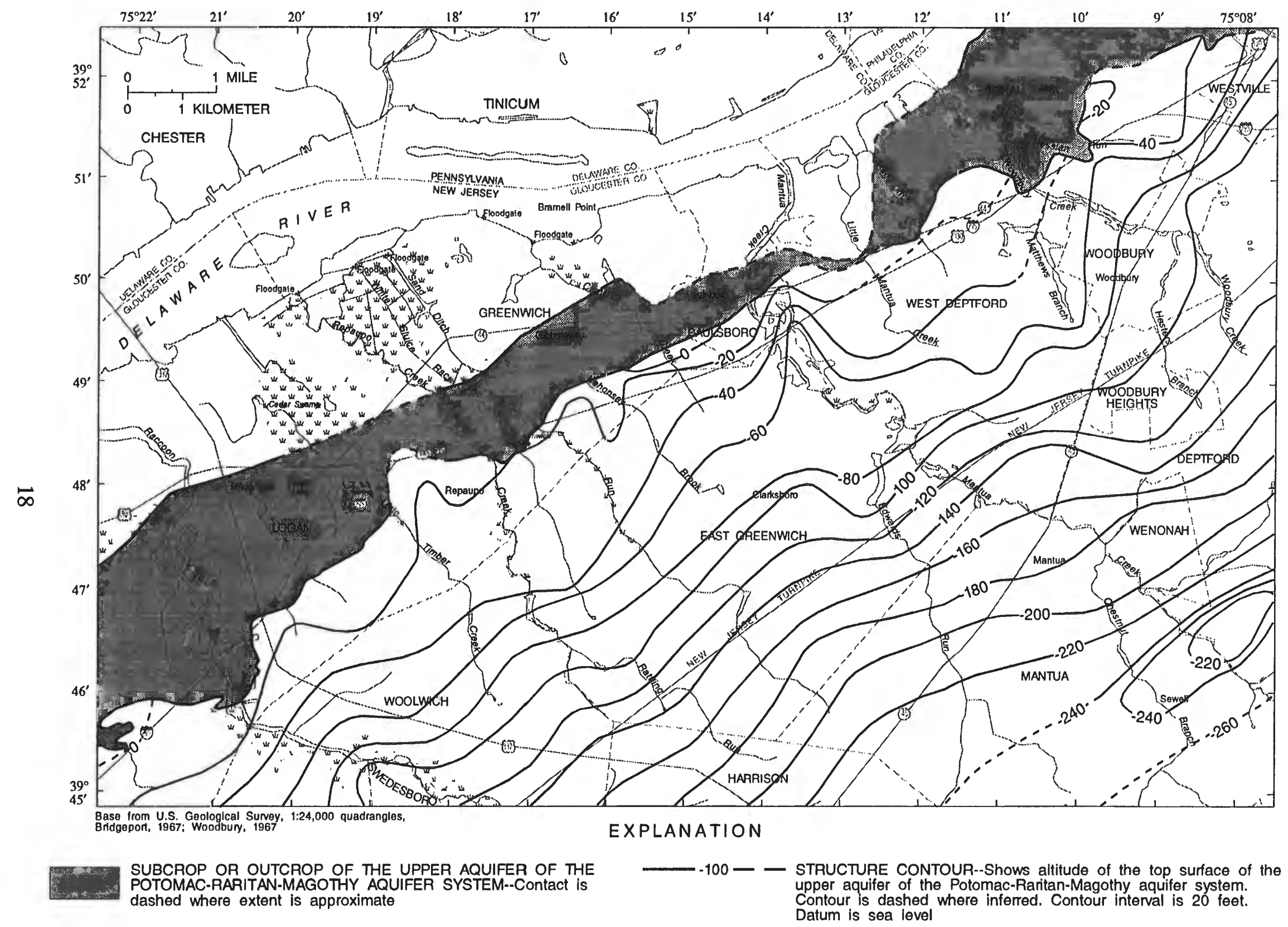

Figure 11. Altitude of the top of the upper aquifer of the Potomac-Raritan-Magothy aquifer system in the Greenwich Township, New Jersey, study area. (Modified from Barton and Kozinski, 1991, pl. 4a) 


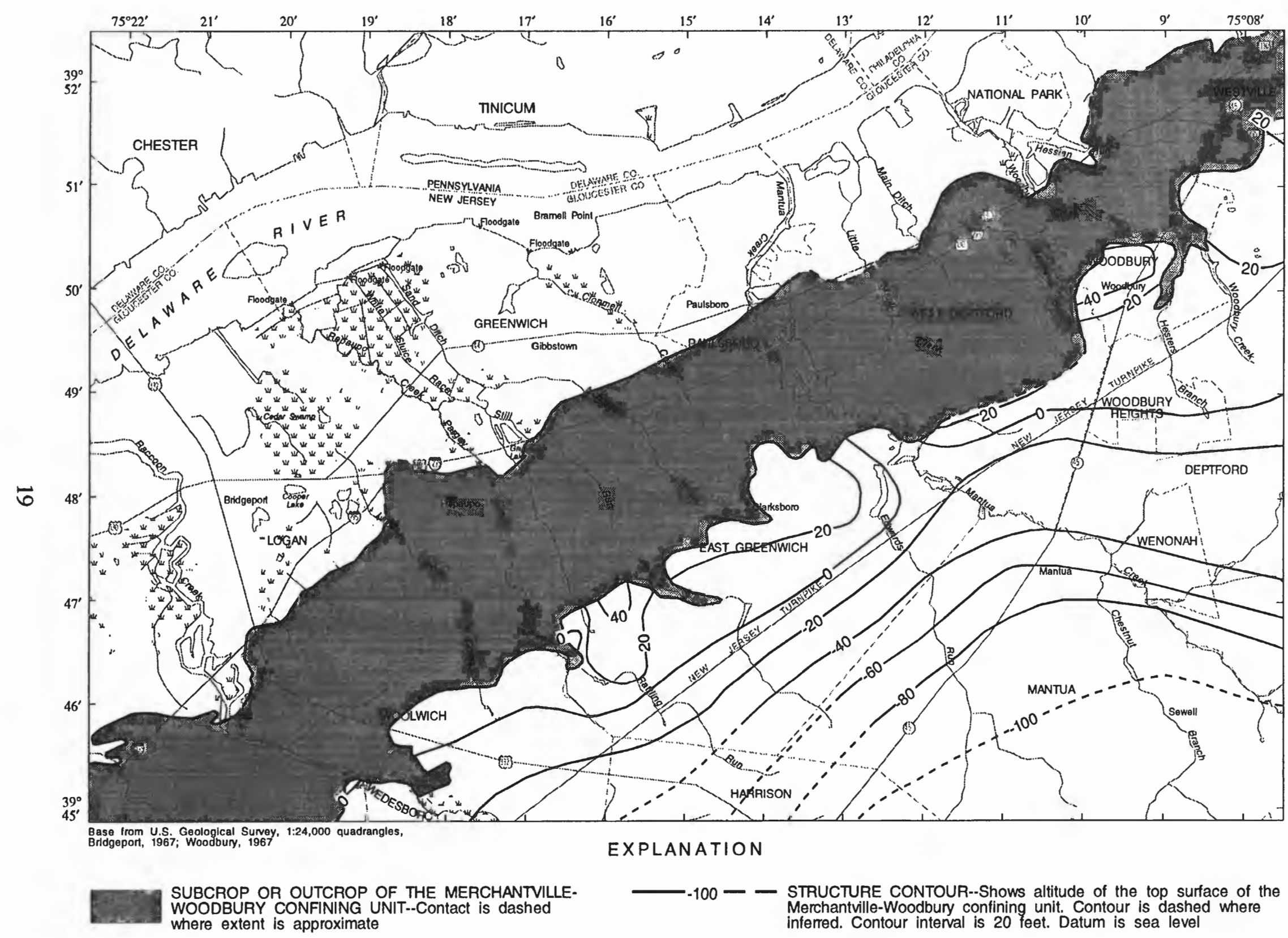

Figure 12. Altitude of the top of the Merchantville-Woodbury confining unit in the Greenwich Township, New Jersey, study area. (Modified from Barton and Kozinski, 1991, pl. 3b) 


\section{Predevelopment Conditions}

The generalized sections shown in figure 13 illustrate the ground-water-flow system in the Greenwich Township study area under predevelopment conditions. Before development water entered the ground-water system through infiltrating precipitation that recharged at the water table and from lateral ground-water flow into the study area. Throughout the study area, the water table is found either in the surficial (upper Cenozoic) deposits or in the outcrop or subcrop of the underlying Cretaceous-age sediments (fig. 13). Predevelopment ground-water flow within the confined Potomac-Raritan-Magothy aquifer system generally was west- and northwestward into the study area from topographically elevated regional recharge areas northeast of the study area (fig. 14) (Hardt and Hilton, 1969, p. 12; Barksdale and others, 1958, p. 102; Martin, in press, figs. 30-32). Ground water discharged to the Delaware River and tributary streams that cross the outcrop areas of the Potomac-Raritan-Magothy aquifer system (figs. 4-12) (Barksdale and others, 1958, p. 108-112; Hardt and Hilton, 1969, p. 12-13).

Regional patterns of predevelopment ground-water flow in the upper aquifer of the Potomac-Raritan-Magothy aquifer system and in the Englishtown aquifer system are shown in figure 14. Ground-water flow in the Englishtown aquifer system is bounded downdip where the aquifer pinches out. Water flowing downdip either flows through confining units to an adjacent aquifer or flows back updip to discharge in a topographically low area in the outcrop. Regional flow patterns in the upper, middle, and lower aquifers are considered to have been similar before development. The fresh ground-water-flow system of the Potomac-Raritan-Magothy aquifer system extends downdip to the interface with saline ground water (Gill and Farlekas, 1976). Flow in the regional confined aquifers is driven by recharge from areas where the aquifers crop out at relatively high altitudes. Ground water flows through the aquifer and discharges where the aquifer crops out at low altitudes, where stream channels tributary to the Delaware River are incised (fig. 14) (Hardt and Hilton, 1969, p. 12; Barksdale and others, 1958, p. 102).

Water that recharges the ground-water system in the study area flows locally and discharges to small streams and surface-water bodies that drain to the Delaware River. Surfacewater bodies, including streams, lakes, and wetlands, cover 10 to 15 percent of the Greenwich Township study area. Under predevelopment conditions, all streams in the Coastal Plain of New Jersey probably were gaining flow from the aquifers (fig. 13).

Mean annual precipitation in the Greenwich Township study area is $42.3 \mathrm{in} / \mathrm{yr}$ (Barton and Kozinski, 1991). Evapotranspiration in the study area is estimated to be 50 percent of precipitation, or 21.1 in/yr (Barksdale and others, 1958, p. 28; Hardt and Hilton, 1969, p. 54; Forman, 1979), and overland runoff is only about $2.2 \mathrm{in} / \mathrm{yr}$ because most surface materials have a high infiltrative capacity (Barton and Kozinski, 1991). An average precipitation of $42.3 \mathrm{in} / \mathrm{yr}$ minus losses to evapotranspiration (21.1 in/yr) and direct runoff ( $2.2 \mathrm{in} / \mathrm{yr}$ ) yields a net ground-water recharge of approximately $19.0 \mathrm{in} / \mathrm{yr}$. This rate of ground-water recharge probably is reduced in areas where confining-unit material crops out at land surface (fig. 13) and near streams.

The Delaware River and its tributaries incise the Potomac-Raritan-Magothy aquifer system. The Delaware River is tidal within the study area; the Delaware River stage at the U.S. Geological Survey tide gage at Bramell Point in Paulsboro Borough varies daily within an average range from $2.4 \mathrm{ft}$ below mean sea level to $3.4 \mathrm{ft}$ above mean sea level. Tidal action in the river has created extensive tidal wetlands in the areas of tributary confluences. Estimates of ground-water discharge to streams in the study area by direct measurement are unavailable because of the effect of tides and tide gates. 


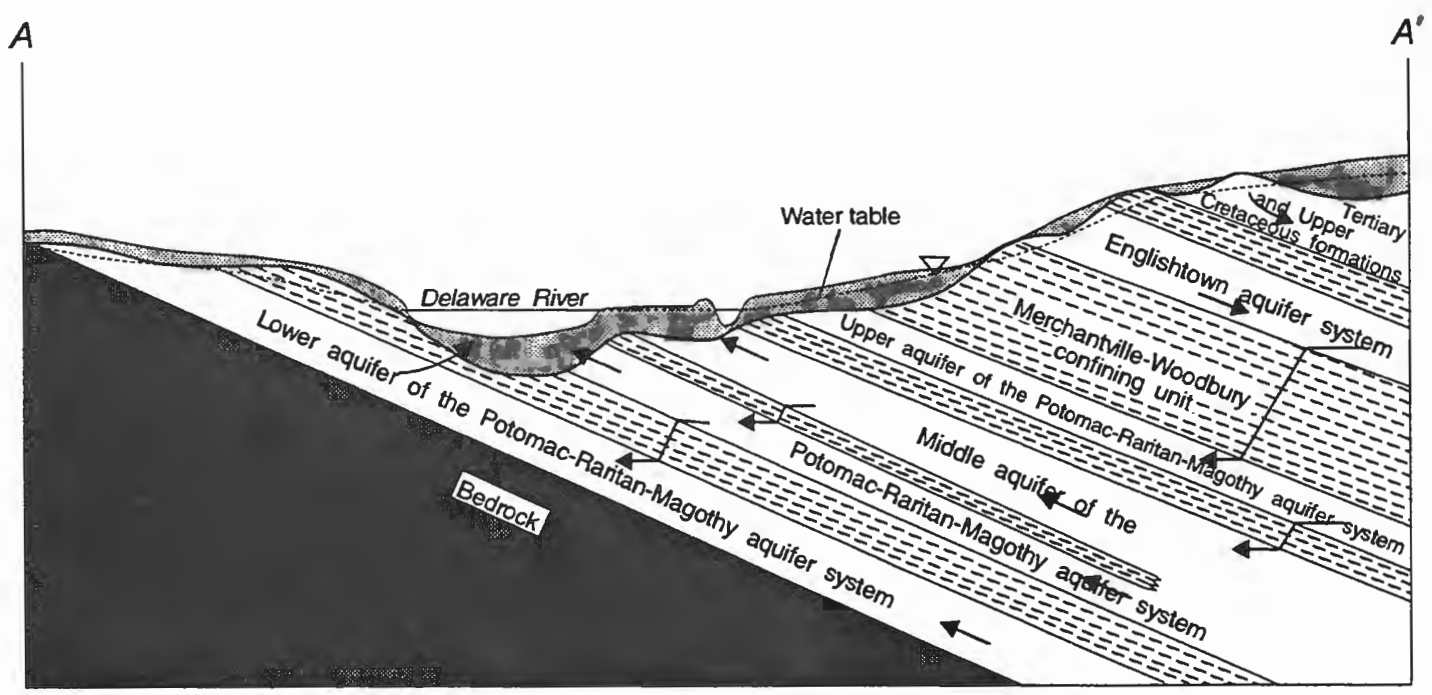

NOT TO SCALE

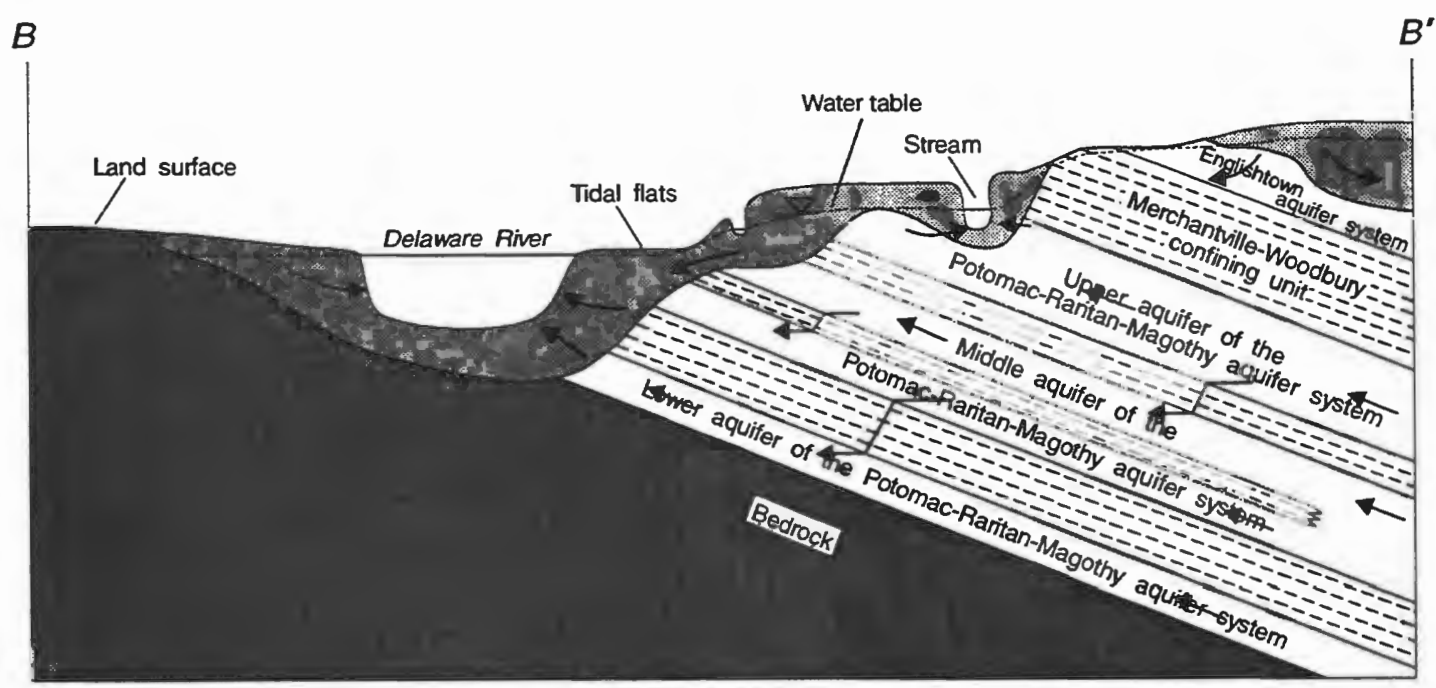

NOT TO SCALE

\section{EXPLANATION}

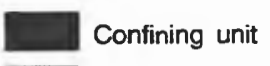

Upper Cenozoic deposits

4 Generalized direction of ground-water flow

Figure 13. Generalized hydrogeologic sections through the major hydrogeologic units in the Greenwich Township, New Jersey, study area depicting the ground-water-flow system under predevelopment conditions. (Location of sections shown in fig. 2) 

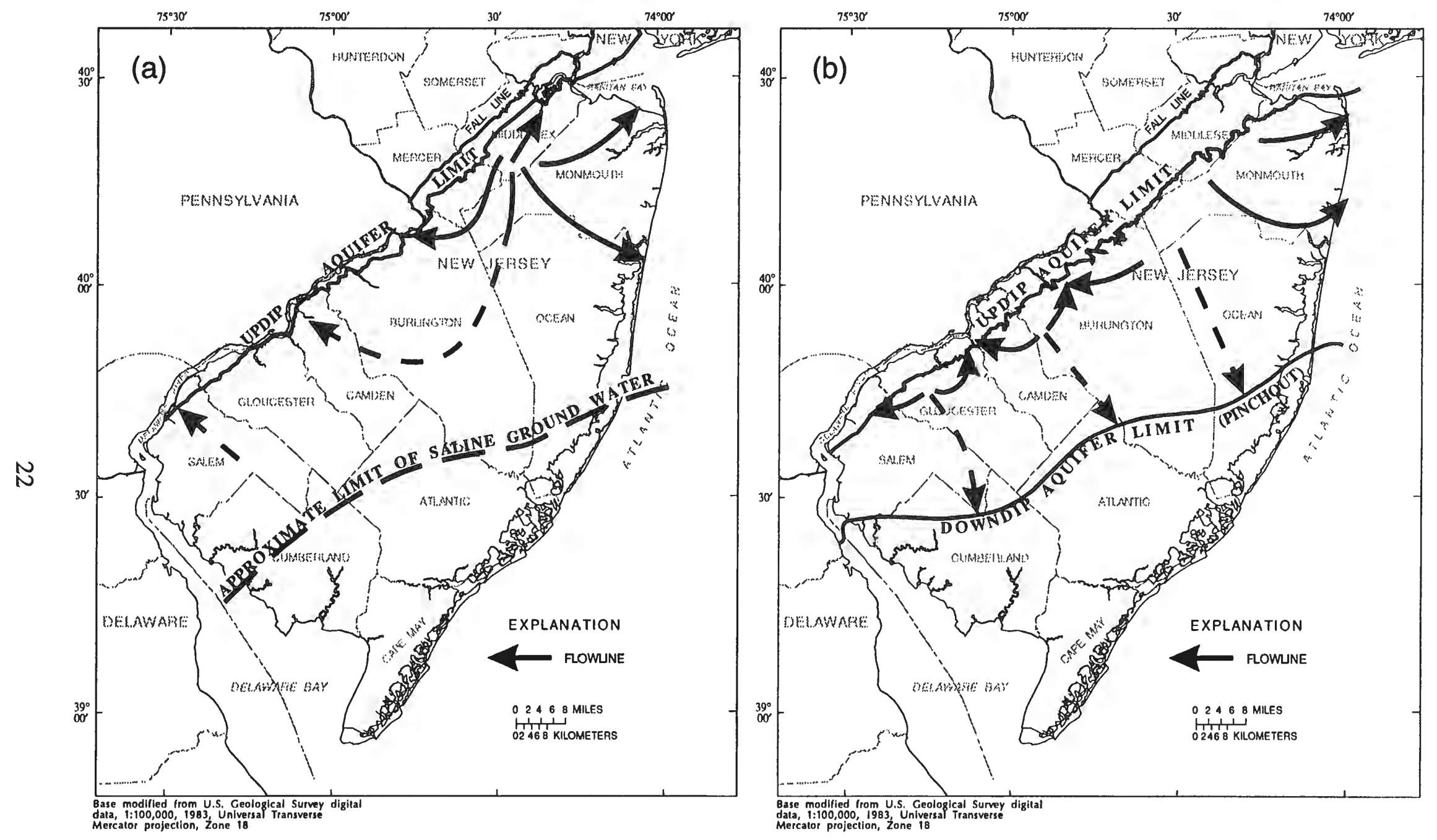

Figure 14. Ground-water-flow patterns in the (a) upper aquifer of the Potomac-Raritan-Magothy aquifer system and (b) Englishtown aquifer system under predevelopment conditions. (Modified from Martin, in press, fig. 21) 


\section{Effects of Development}

Ground-water withdrawals from within and outside the study area and the construction of tide gates at the mouths of Delaware River tributaries have significantly changed the pattern and rate of ground-water flow in the Potomac-Raritan-Magothy aquifer system (fig. 15). Water levels in the Englishtown aquifer system in 1988 (Rosman and others, 1995), however, indicate that ground-water-flow patterns near the study area have not changed significantly as a result of development. Water levels in the Englishtown aquifer system ranged from greater than $60 \mathrm{ft}$ above sea level in the subcrop in Camden County to less than $20 \mathrm{ft}$ above sea level in the east-southeastern part of the study area. Flow within the confined part of the aquifer is east-southeastward. On the basis of head measurements made in 1986, Barton and Kozinski (1991) indicate that ground water within the study area probably is flowing downward through the Merchantville-Woodbury confining unit to the upper aquifer of the Potomac-Raritan-Magothy aquifer system in response to pumping.

The Potomac-Raritan-Magothy aquifer system and overlying upper Cenozoic deposits are the principal source of potable water for the area and yielded more than 99 percent of the total reported ground-water withdrawals in the study area in 1986 (Barton and Kozinski, 1991). Barton and Kozinski (1991) list the major production wells (production capacities equal to or greater than 100,000 gal/d) and withdrawals for 1973, 1978, and 1983-86 as reported in the U.S. Geological Survey New Jersey State Water Use Data System (SWUDS). They also detail types of water use and historical changes in water use within the study area. In 1986, most ground-water withdrawals ( 99 percent) were from 83 large production wells that were divided nearly evenly between public-supply and self-supplied industrial uses; a few wells were used for commercial and irrigation purposes. Although agricultural withdrawals are poorly documented, they probably are small in comparison to public-supply and industrial pumpage (Vowinkel, 1984, p. 14). Also, some ground water is pumped to contain and recover contaminated ground water in the unconfined parts of the ground-water system at industrial sites in Paulsboro Borough and Greenwich, Logan, and West Deptford Townships (Barton and Kozinski, 1991).

Total withdrawals from the Potomac-Raritan-Magothy aquifer system, and withdrawals from the upper, middle, and lower aquifers in 1956 through 1986, are shown in figure 16. Almost one-half of the total withdrawals from the aquifer system during the 1970's was from the lower aquifer. Total withdrawals from the aquifer system were nearly constant from 1976 through 1986. Average withdrawals during this period amounted to $17.8 \mathrm{Mgal} / \mathrm{d}$, and the distribution of withdrawals among the aquifers was consistent. Major withdrawal centers for all three aquifers are concentrated in the eastern part of the region and along the Delaware River in West Deptford and Greenwich Townships and Paulsboro Borough (Barton and Kozinski, 1991, figs. 28-31). Withdrawals in the Pennsylvania part of the study area generally are not significant.

Urban development has been accompanied by a significant amount of construction along the Delaware River waterfront. Extensive networks of dikes along the riverbank and tidal floodgates across the mouths of tributary streams have been built. As a result of this construction, areas that had been tidal wetlands do not flood at high tide, but drain to the Delaware River during low-tide stages. Consequently, the average stage in streams that flow through these parts of Gloucester Township and Paulsboro Borough ranges from 1.5 to $2.5 \mathrm{ft}$ below sea level (M.A. Peterson, U.S. Natural Resources Conservation Service, written commun., 1986; J.R. Redmond, Greenwich Township, written commun., 1986). Therefore, ground-water levels in the vicinity of these streams can be below sea level.

Figure 17 depicts a conceptual representation of ground-water-flow patterns under developed conditions, such as those in 1986. Ground-water withdrawals have had major effects on ground-water-flow directions in the Potomac-Raritan-Magothy aquifer system. Ground water 
(a)

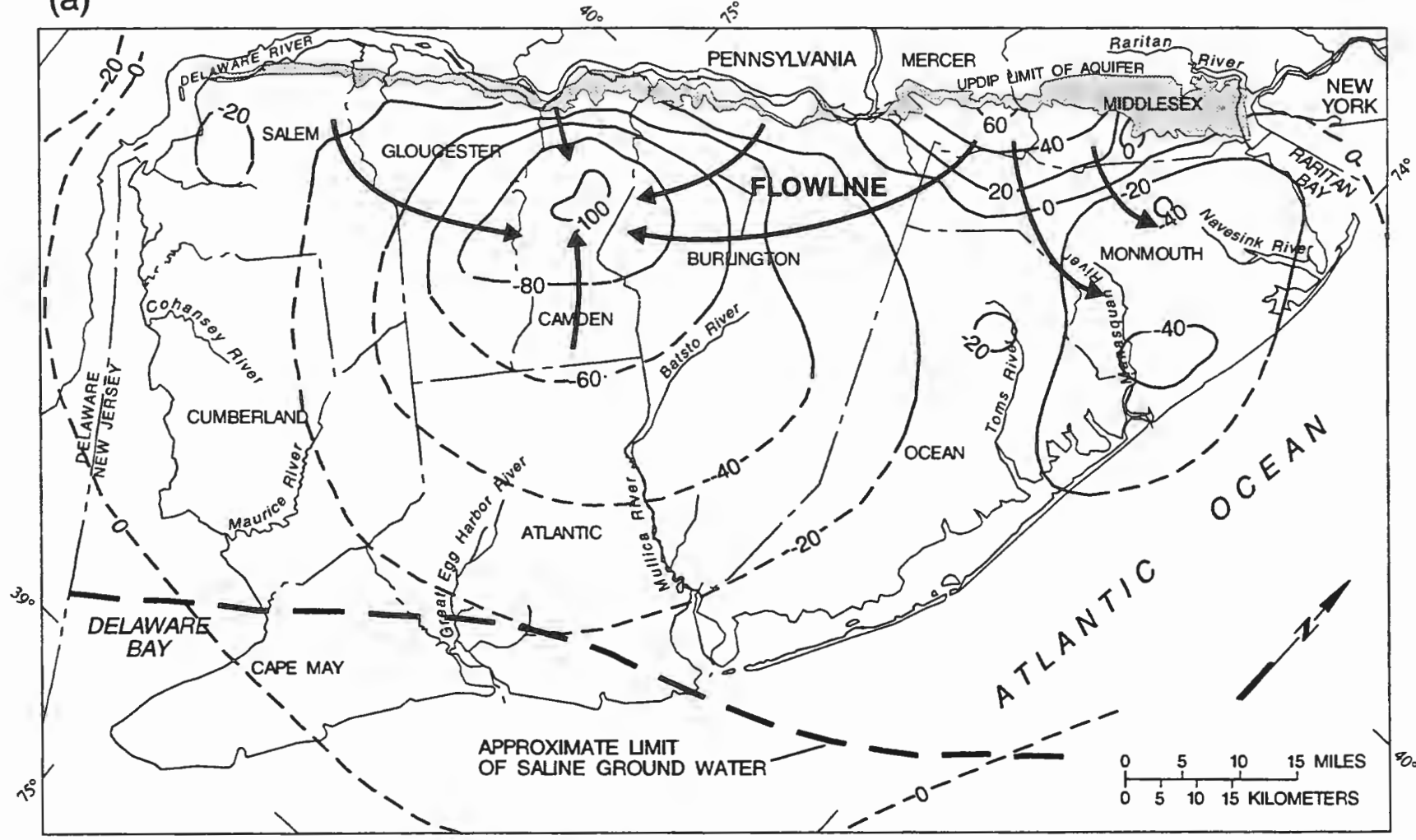

Base trom U.S. Geological Survey digital data, 1:2,000,000, 1972

EXPLANATION

Universal Transwerse Mercator projection, Zone 18 OUTCROP OF THE MAGOTHY FORMATION

(Modified from Zapecza, 1989))

- -20- - POTENTOMETRIC CONTOUR-Shows altitude at which water would have stood in tightly cased wells. Dashed where approximate. Contour interval 20 feet

(b)

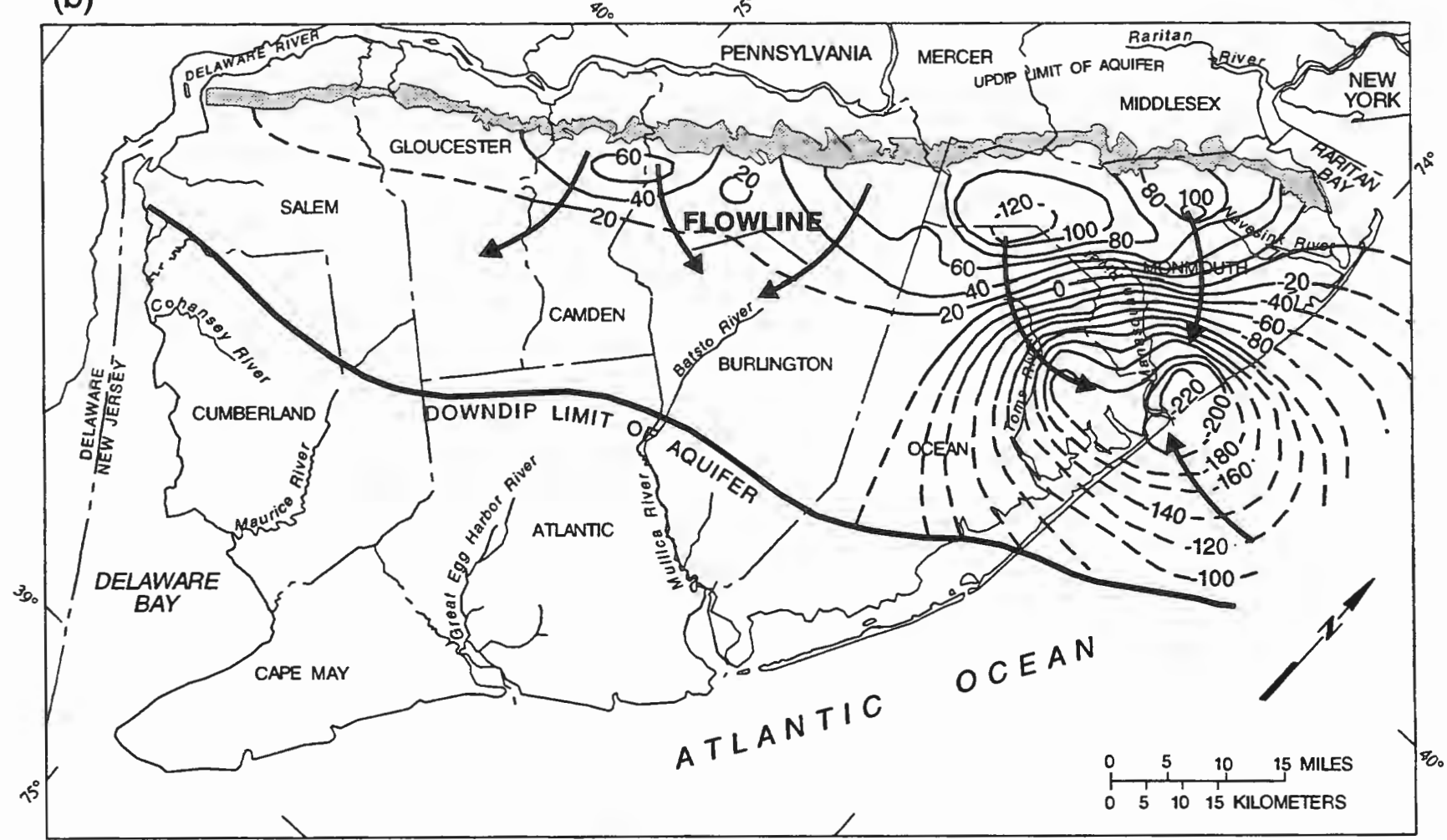

Base from U.S. Geotogical Survey digital data, 1:2,000,000, 1972
Universal Transverse Mercator projection, Zone 18

EXPLANATION

ENGUSHTOWN FORMATION

OUTCROP OF THE ENGUSHTOV
(Modified from Zapecza, 1989)

- 20 - - POTENTIOMETRIC CONTOUR-Shows altitude at which water would have stood in tightly cased wells. Dashed where approximate. Contour interval 20 feet

Figure 15. Potentiometric surface in the (a) upper aquifer of the Potomac-Raritan-Magothy aquifer system and (b) Englishtown aquifer system in 1988. (Modified from Rosman and others, 1995) 


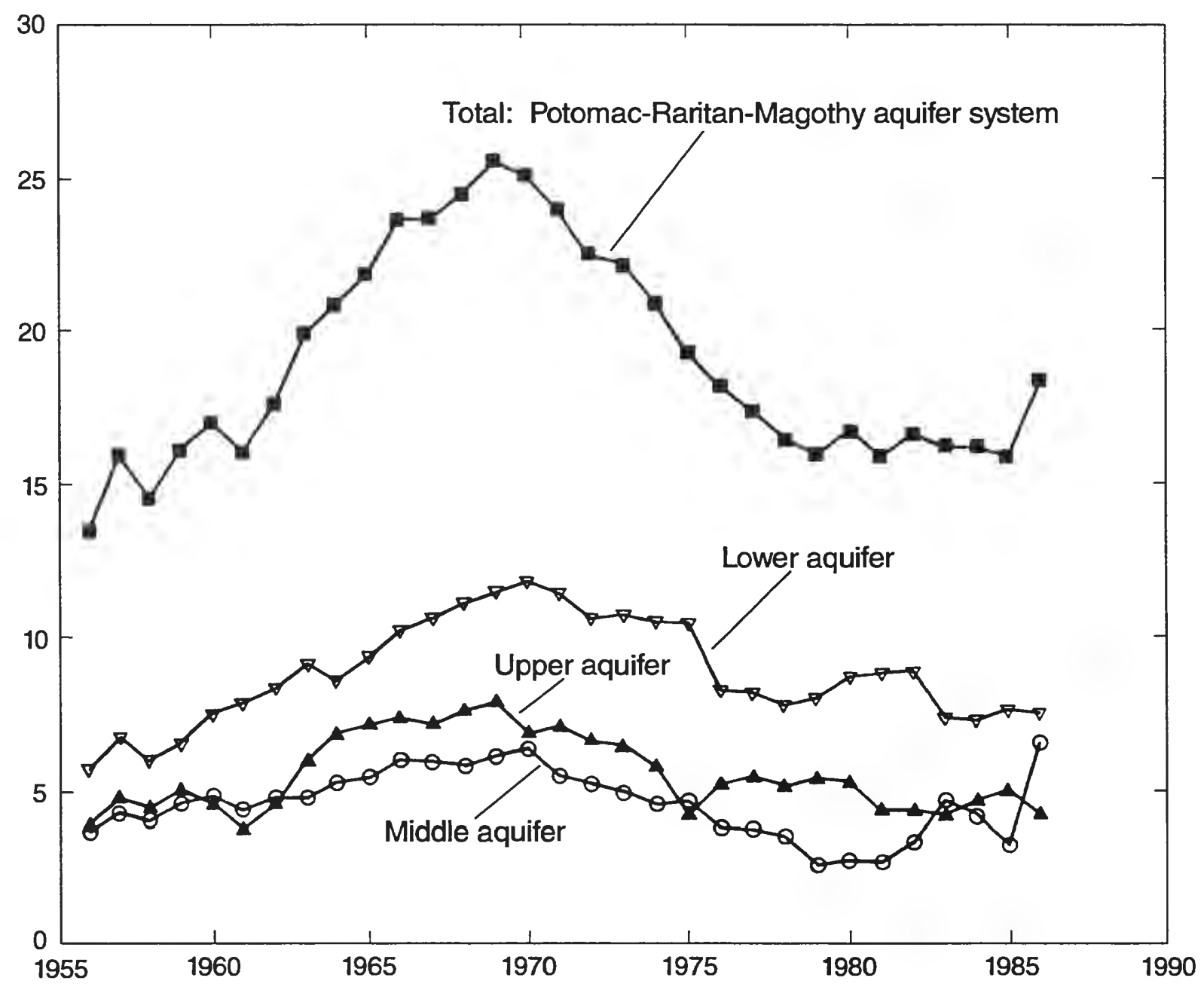

Figure 16. Total rate of withdrawal and rates of withdrawal from the upper, middle, and lower aquifers of the Potomac-Raritan-Magothy aquifer system in the Greenwich Township, New Jersey, study area, 1956-86. (From Barton and Kozinski, 1991, fig. 5c) 


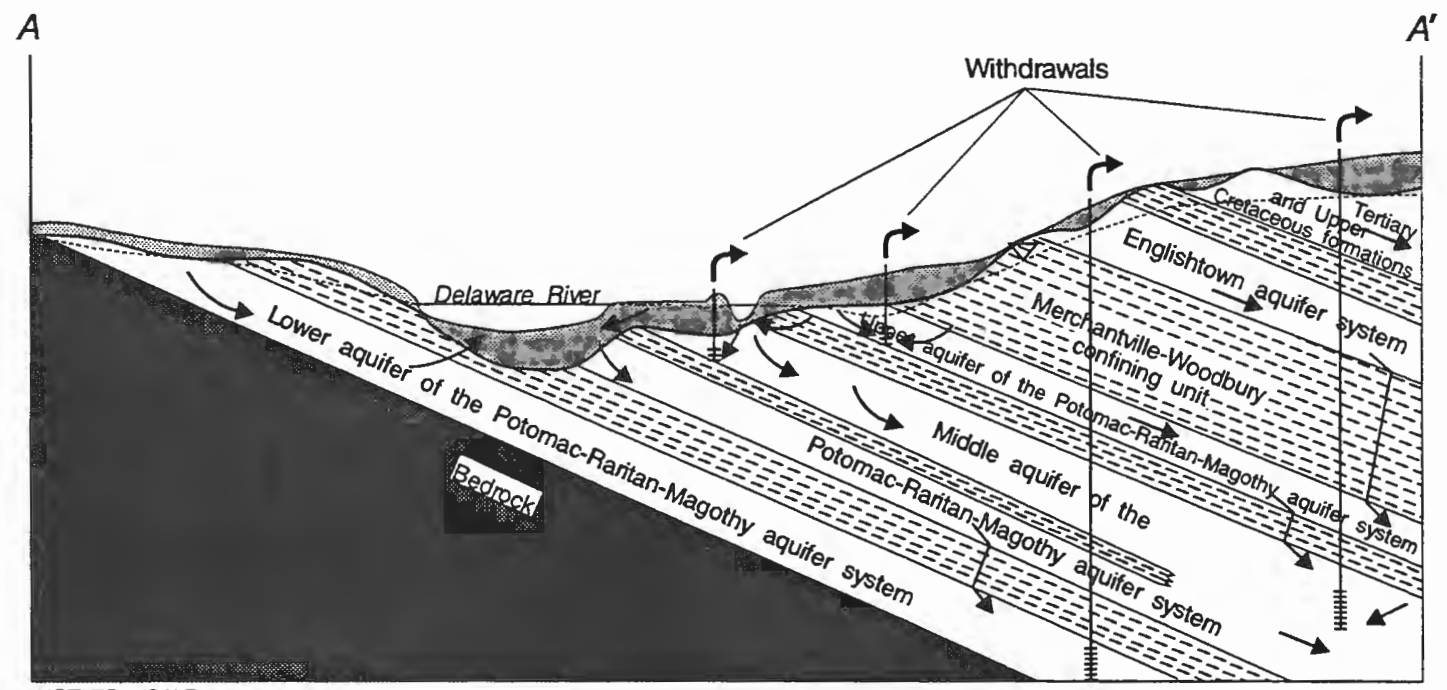

NOT TO SCALE

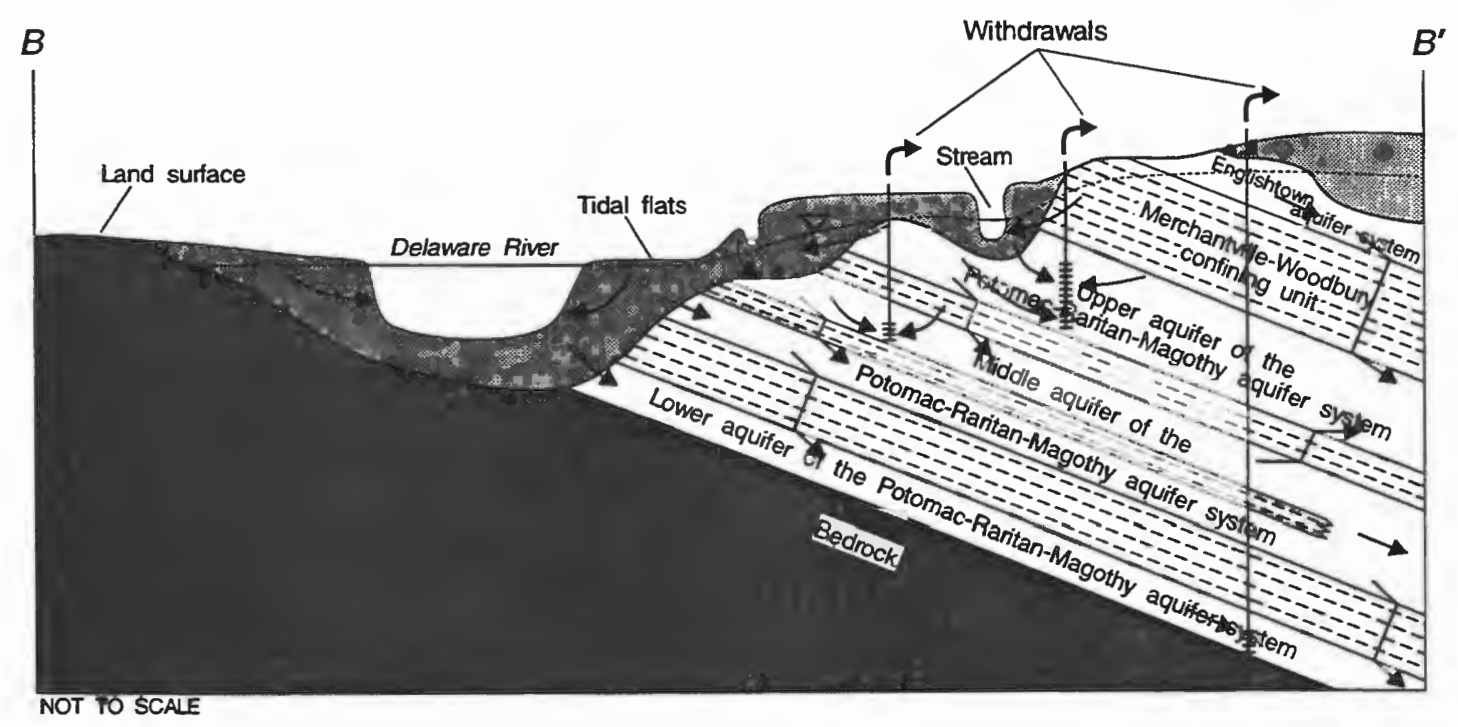

EXPLANATION

$\square$ Confining unit
\begin{tabular}{l|l}
$\square$ & Screened well \\
$\longleftarrow$ Upper Cenozoic deposits & Generalized direction of ground-water flow
\end{tabular}

Figure 17. Generalized hydrogeologic sections through the major hydrogeologic units in the Greenwich Township, New Jersey, study area depicting the ground-water flow system under developed conditions. (Location of sections shown in fig. 2) 
within the Potomac-Raritan-Magothy aquifer system before development flowed northwest toward the outcrop area, into the study area (fig. 13), but in 1986 ground water flowed in a downdip, southeasterly direction (fig. 17). This change in the regional flow pattern throughout the aquifer system has been caused by extensive withdrawals of ground water from the PotomacRaritan-Magothy aquifer system in and near northern Camden (Eckel and Walker, 1986), eastern Gloucester, and western Burlington Counties and has resulted in decreased heads in both the unconfined part (Paulachok and Wood, 1984) and the confined part of the aquifer system (Eckel and Walker, 1986, p. 11-12). The center of the cone of depression in the upper aquifer is located in central Camden County and was more than $90 \mathrm{ft}$ below sea level in 1983 (Eckel and Walker, 1986).

Within the study area, ground-water withdrawals produce local cones of depression, which are superimposed on the much larger regional cone of depression. The water table in the study area has been drawn down to the degree that flow is induced directly from the Delaware River. Some reaches of tributary streams also are losing flow to the ground-water system (Barton and Kozinski, 1991). Consequently, an area that was characterized before development as being a major area of ground-water discharge to streams (Winograd and Farlekas, 1974) was, in 1986, a source of induced recharge to satisfy ground-water pumping. This change can be seen by comparing figures 13 and 17.

The Delaware River is saline in part of the study area as a result of the mixing of seawater with freshwater that flows into the estuary. The long-term annual point of saline-water invasion into the Delaware River is within the study area at Chester, Pennsylvania (Anderson and others, 1972, p. 381, fig. 7). Extensive ground-water withdrawals from aquifers in the southern Coastal Plain of New Jersey have produced hydraulic gradients in the Potomac-Raritan-Magothy aquifer system that potentially could allow saline water to migrate downward from the Delaware River into the aquifer system (Barksdale and others, 1958, p. 106-108; Greenman and others, 1961, p. 76-81; Barton and Kozinski, 1991).

\section{SIMULATED GROUND-WATER FLOW}

The ground-water-flow model described herein was developed as a tool for evaluating recent (1986) ground-water-flow conditions in the Potomac-Raritan-Magothy aquifer system in the area of Greenwich Township, New Jersey.

The final model representation of the ground-water-flow system derived through the calibration process is presented in the following sections of this report. The model is assumed to provide a working representation of the structure and operation of the ground-water system. Simulation results are discussed to provide a quantitative understanding of the patterns and distribution of ground-water flow under recent (1986) conditions.

\section{Model Design}

The ground-water-flow system was simulated by use of the ground-water-flow-model code MODFLOW (McDonald and Harbaugh, 1988). This code is based on a numerical finitedifference approximation of the partial-differential equation for three-dimensional ground-water flow. A quasi-three-dimensional approach is used to simulate aquifers as layers in which flow is horizontal; flow through the confining units is assumed to be vertical. Other features of the code are used to represent hydrologic features such as streams, lakes, recharge, and unconfined flow. 


\section{Grid}

A schematic representation of the model grid showing the hydrogeologic framework and hydrologic boundaries of the system used in the model is shown in figures 18 and 19. The model represents the ground-water system as four distinct model layers: the upper aquifer (model layer 1), the upper part of the middle aquifer (model layer 2), the lower part of the middle aquifer (model layer 3), and the lower aquifer (model layer 4) of the Potomac-Raritan-Magothy aquifer system. The confining units are represented solely as restrictions to vertical flow between model layers (aquifers).

The confined part of each model layer has a direct lateral connection with the unconfined system at the aquifer's subcrop or outcrop. The unconfined system was represented in the model as a continuous system that consists of the subcrops of the four aquifers and the upper Cenozoic deposits that overlie the subcrop areas of the aquifers and confining units of the Potomac-RaritanMagothy aquifer system (fig. 14). Each model layer represents a fraction of the upper Cenozoic deposits and extends through them to the northwestern boundary of the model. Where the confining units are absent, ground water can flow unimpeded between all continuous layers.

The modeled area was discretized areally by use of a uniformly spaced finite-difference grid as shown in figure 19. The grid consists of 70 columns and 46 rows. Each cell is $1,000 \mathrm{ft}$ by $1,000 \mathrm{ft}\left(.036 \mathrm{mi}^{2}\right)$.

\section{Temporal Assumptions}

Hydrologic conditions in the ground-water system in the Greenwich Township study area in 1986 were assumed to be in equilibrium. For these conditions to exist, it is necessary that recharge to and discharge from the aquifer system are nearly constant and balance. Thereby ground-water levels and storage (the amount of water stored within the hydrogeologic units) remain constant. Where these conditions prevail, a steady-state model can be used to evaluate the operation of a ground-water system. It is estimated that the major stress on the aquifer system in the study area (pumping) had remained fairly constant for the 10-year period 1976-86 (fig. 16). Also, continuous water-level data from within the study area indicate that ground-water levels were approximately the same during the same period (Barton and Kozinski, 1991, fig. 6). These factors indicate that the equilibrium assumption is acceptable.

\section{Boundary Conditions}

Several of the model boundaries coincide with naturally occurring hydrologic features in the ground-water system (fig. 18). The updip boundary, where aquifers pinch out to the northwest, is assumed to be a no-flow boundary. The underlying contact with impermeable bedrock is a no-flow boundary. The water-table boundary across which recharge from precipitation occurs is assumed to be a constant-flow boundary. Where the water table is present in the outcrop area of the Woodbury-Merchantville confining unit, recharge occurs at a greatly reduced rate compared to recharge in aquifer outcrop areas. The Delaware River is represented as a constant-head boundary at $1 \mathrm{ft}$ above sea level, the average stage in the study area. The river is simulated areally by cells where it incises the upper model layer (fig. 18). The model assumes a direct hydraulic connection between the Delaware River and the ground-water system. The boundaries representing streams and wetlands in the unconfined areas of the aquifers are represented as head-dependent-leakage boundaries (fig. 19). 


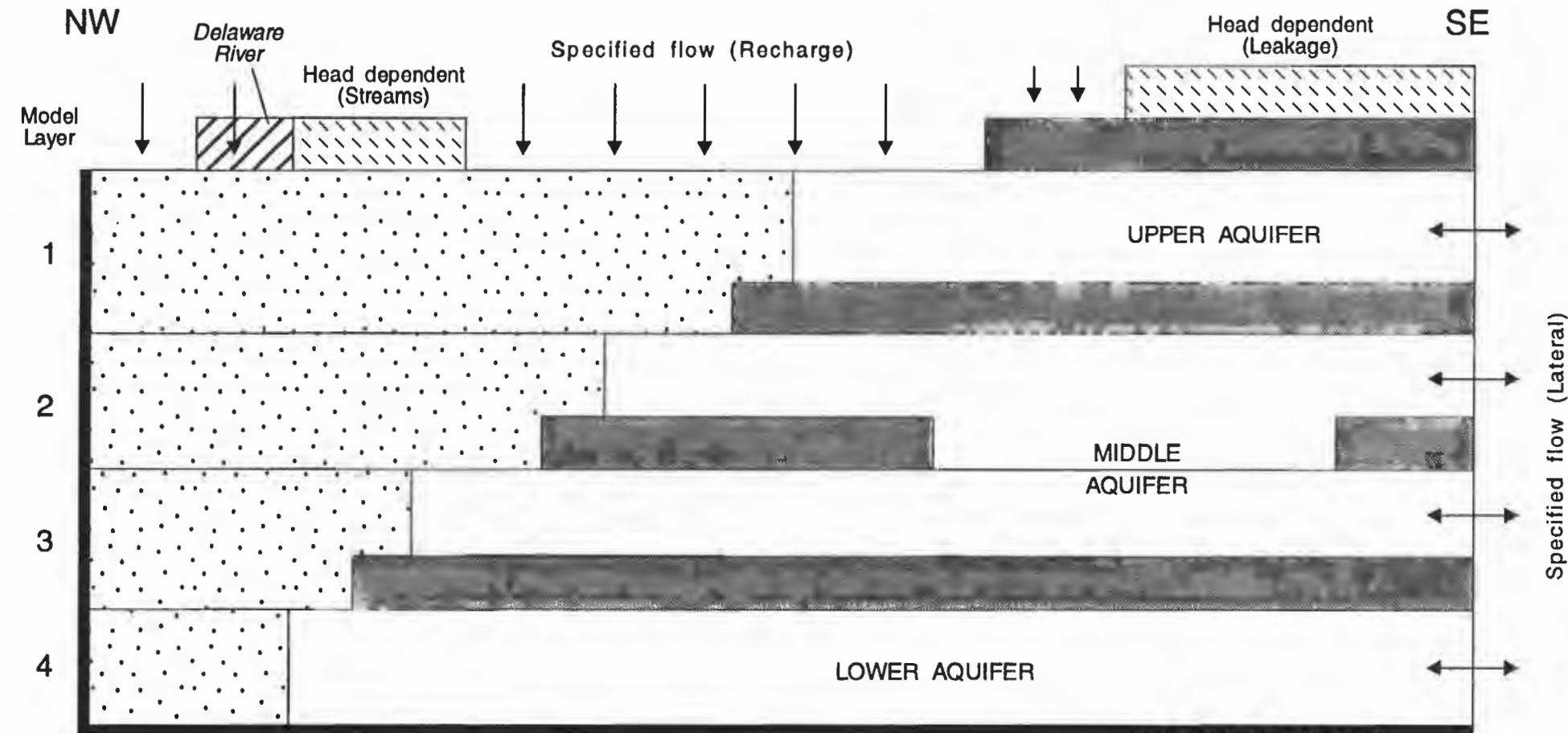

\section{EXPLANATION}

$\therefore$ Upper Cenozoic deposits

POTOMAC-RARITAN-MAGOTHY AQUIFER SYSTEM

Confining unit

$\square$ Aquifer

Figure 18. Schematic section through model layers showing hydrogeologic units and boundary conditions used in the model of the Greenwich Township, New Jersey, study area. 


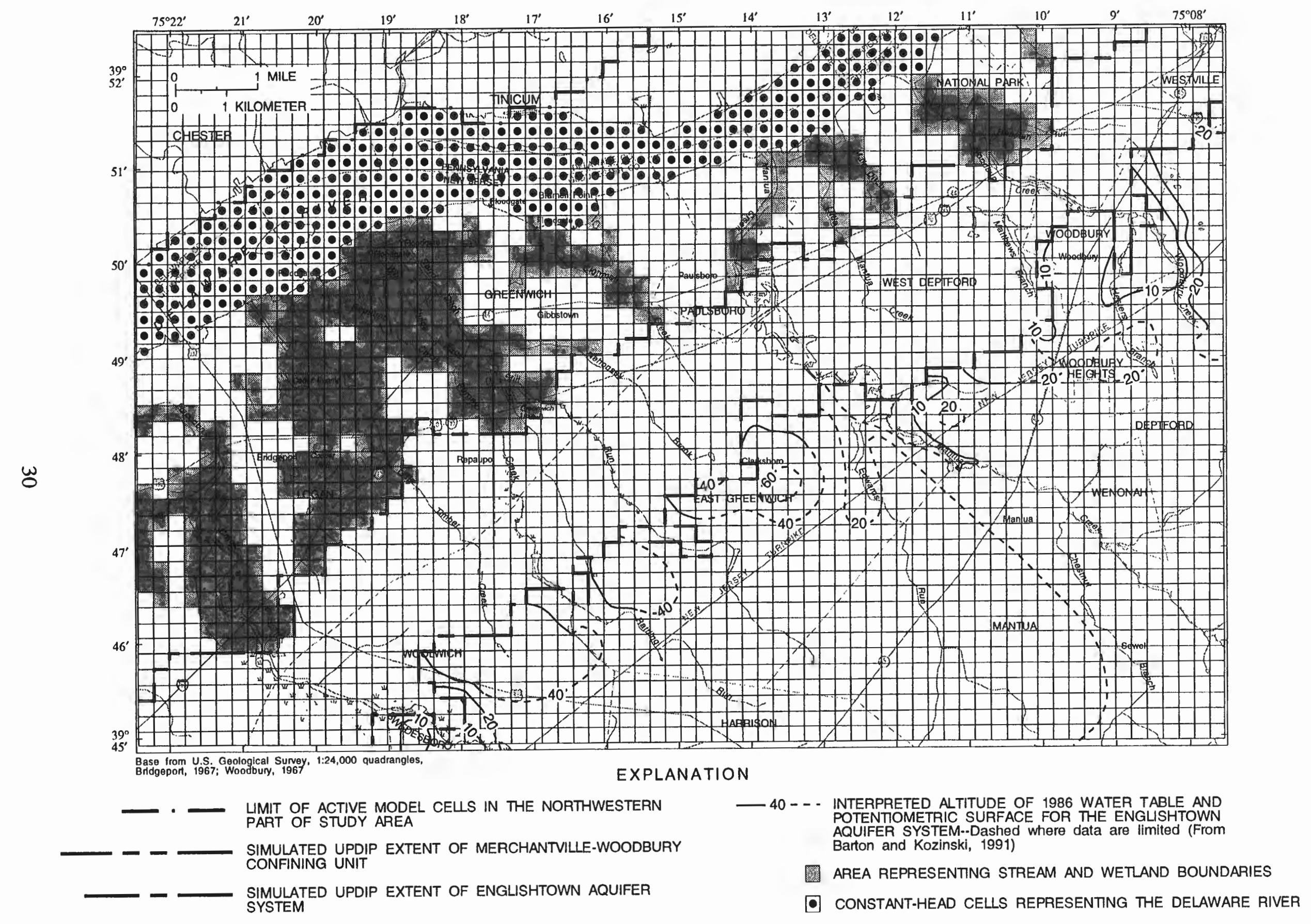

Figure 19. Finite-difference grid, locations of stream and river cells, and simulated updip extents of the Merchantville-Woodbury confining unit and Englishtown aquifer system used in the model of the Greenwich Township, New Jersey, study area. 
Although the ground-water flow within the Englishtown aquifer system is not relevant to this investigation, leakage from the Englishtown aquifer system downward to the PotomacRaritan-Magothy aquifer system is represented by a head-dependent-leakage boundary condition. This permits leakage to respond to head changes within the upper aquifer of the Potomac-RaritanMagothy aquifer system. The estimated constant-head values in the Englishtown aquifer system are represented from the interpreted potentiometric surface (fig. 19). The potentiometric surface was based on water levels measured in wells in the Englishtown aquifer system (Eckel and Walker, 1986; Rosman and others, 1995) and stream elevations on U.S. Geological Survey 1:24,000-scale topographic maps.

Lateral boundaries that did not correspond to natural hydrologic boundaries are represented as specified-flow boundaries. The process for quantifying and evaluating these boundary flows is discussed in the section on calibration.

\section{Calibration}

The model was calibrated by simulation of a steady-state hydrologic condition that occurred under recent (1986) conditions during the mid 1980's. The model was evaluated by comparing the simulated head distribution to the areal distribution of heads measured in August and September 1986. Field measurements and observations, such as the locations of gaining and losing stream reaches, and estimates of water-budget components, such as net recharge, were also considered in evaluating simulated response. The model representation of the ground-water system was adjusted until simulation results reproduced the magnitude and direction of gradients as defined by interpreted contours of measured water levels and were consistent with the conceptual model.

Characteristics of the system that were adjusted during model calibration include the representation of water-transmitting properties and the mathematical approximation of hydrologic boundaries. The initial hydrogeologic data used to construct the model were assembled from the results presented in Barton and Kozinski (1991) and from previous investigations. Values of hydrogeologic parameters (such as transmissivity and leakance) reported for the New Jersey Regional Aquifer System Analysis model (Martin, in press) generally were used as a guide; however, the contrast in scales between that analysis and this allows for differences in parameter values. The model representation of the system's hydrogeologic framework was not changed during calibration because it was felt to be a reliable interpretation of stratigraphic data. Values of water-transmitting properties (such as aquifer transmissivity, confining-unit vertical hydraulic conductivity, and streambed conductance) were varied during the calibration of the model.

The model is bounded laterally by artificial boundaries on its eastern, southern, and part of its western border. That is, these boundaries do not correspond to natural hydrologic features which enable accurate mathematical representation of the flow across the boundary in the numerical model. The inclusion of these boundaries in the model can affect the ability to achieve a representation that is consistent with the actual system; these boundaries are approximated by specified-head or -flux boundary conditions that can introduce discrepancies between the resulting ground-water budget and that of the actual system (Franke and Reilly, 1987). Therefore, particular attention was given to the definition and evaluation of these boundary conditions in the model. An iterative procedure was used to define these boundaries in which estimated values of heads were specified and a series of simulations was used to calculate the distribution of boundary fluxes and hydraulic properties. The results were compared to the estimated distribution of flow calculated from measured head data (Barton and Kozinski, 1991, p. 49-56). The calibrated boundary flows were then input as specified-flux boundaries, and adjusted in order to smooth irregularities introduced by errors in specifying the distribution of heads along these boundaries and to make them consistent with the conceptual model. 


\section{Hydrogeologic Parameters}

The values of specific hydrogeologic parameters, as well as the basis for estimating those values, are presented in the following section. Hydrogeologic parameters include recharge, ground-water withdrawals, steambed conductive properties, aquifer transmissivity, and confiningunit leakance.

\section{Recharge}

Recharge occurs when precipitation infiltrates the land surface, percolates to the water table, and enters the ground-water system. The rate of ground-water recharge is estimated to be equal to long-term precipitation minus losses caused by evapotranspiration and runoff. Recharge was applied to all unconfined aquifer cells (fig. 19) at a rate of $19 \mathrm{in} / \mathrm{yr}$, a rate estimated from results of water-budget analysis (Barton and Kozinski, 1991). This value is consistent with the value $(20 \mathrm{in} / \mathrm{yr})$ used in the ground-water-flow model developed as part of the New Jersey Coastal Plain Regional Aquifer System Analysis (Martin, in press) and with the value of $16 \mathrm{in} / \mathrm{yr}$ used in a model of ground-water flow in the area of Camden, New Jersey (Navoy and Carleton, 1995).

It was assumed that recharge enters the upper aquifer at a reduced rate through the narrow band that represents the outcrop of the overlying Merchantville-Woodbury confining unit (fig. 19). In this area, recharge is assumed to be restricted as it infiltrates through the confining-unit material. Trial-and-error tests using the model indicated that a recharge rate of $2 \mathrm{in} / \mathrm{yr}$ accurately reproduced measured data; the sensitivity of simulated results to this parameter, however, is low.

\section{Withdrawals}

Ground-water withdrawals simulated in the model consisted of major production wells with production capacities equal to or greater than $100,000 \mathrm{gal} / \mathrm{d}$. The data are recorded in the U.S. Geological Survey State Water Use Data System (SWUDS). Each withdrawal was located in the model cell (row, column, and layer) that corresponds to the position and screened interval of the well. Node locations for withdrawal wells within the model grid were assigned from the latitude and longitude of each well. Summaries of the 1986 withdrawals that were used in the model (Barton and Kozinski, 1991) indicate that ground-water withdrawals are located mainly in areas where aquifers are shallow because wells in these areas are relatively inexpensive to develop and contain mostly freshwater. The locations of all withdrawal wells that were represented in the model are shown in figures 28-31.

\section{Stream Characteristics}

Ground-water seepage both to and from streams, estuaries, and freshwater and tidal wetlands is a major component of the ground-water-flow system. These hydrologic features are represented in the model as head-dependent discharge boundaries. At these boundaries, the rate of discharge is controlled by the hydraulic conductance of the bed material through which the water flows multiplied by the difference in head between the aquifer and the surface-water body. Streams, estuaries, and wetlands were located in model grid cells (fig. 19) on the basis of digitized information derived from U.S. Geological Survey 1:24,000-scale topographic maps; streamsurface elevations were estimated from the topographic maps. These estimates are assumed to represent long-term average elevations of the stream surfaces and an areal average within each cell. 
Tidal wetlands make up more than 5 percent of the study area and include Cedar Swamp in northern Logan Township and areas near the mouths of the Repaupo Creek and Clonmell Creek drainage basins in Greenwich Township. Parker and others (1964, p. 65) note that wetland regions contain marsh and swamp deposits of dark silt and clay mixed with organic matter that may be sufficiently permeable to allow appreciable amounts of recharge and discharge to pass through them.

Values of bed-material conductance are calculated as the product of hydraulic conductivity and the area of the surface-water body within a grid cell, divided by the bed-material thickness. Stream and wetland areas within each cell were digitized; the streambed thicknesses were estimated arbitrarily to be $5 \mathrm{ft}$. An initial estimate of streambed conductances was made by assigning streambed vertical hydraulic conductivities of about 10 to $20 \mathrm{ft} / \mathrm{d}$, or about one-fifth the horizontal hydraulic conductivity of the uppermost model layer. During model calibration, adjustments in values of streambed conductance changed the amount of flow to the unconfined part of the modeled area. Calibrated streambed hydraulic conductivities ranged from about 0.03 to $27 \mathrm{ft} / \mathrm{d}$. Streambed conductances assigned to cells near the downdip edge of the unconfined area of the aquifer system (typically an area where streams are losing water to aquifers) tended to be low. Other input variables that affect streambed conductance were not varied during calibration.

Measured base-flow data for the streams in the study area are unavailable; therefore, simulated ground-water discharge to streams could not be directly compared to measured data. The calibrated model is considered to give a good indication of net-gaining or net-losing stream reaches (fig. 18) for 1986 conditions. Barton and Kozinski (1991) report that surface water in many stream reaches recharges the shallow ground-water system--that is, the streams are losing streams.

\section{Transmissivity}

Aquifer transmissivity for each cell was determined by multiplying the aquifer thickness by the horizontal hydraulic conductivity. Horizontal hydraulic conductivities were estimated from hydraulic-conductivity data summarized by Barton and Kozinski (1991, tables 5 and 6).

The distribution of transmissivity in each aquifer (model layer) is shown in figures 20-23. Figure 20 shows transmissivity of the confined part of the upper aquifer, and of the outcrops and subcrops of the upper, middle, and lower aquifers, where the ground-water system is unconfined. Parts of the outcrop areas are composed of upper Cenozoic deposits that are represented in model layers 1 through 4, depending on their thickness (fig. 18).

The hydraulic characteristics of the upper Cenozoic deposits are not well known (Barton and Kozinski, 1991). They directly overlie the Cretaceous aquifer systems (fig. 3). A hydraulicconductivity value of $50 \mathrm{ft} / \mathrm{d}$ was estimated for the upper Cenozoic deposits. This value is appropriate for the lithologies of this unit. The water table exists either in the upper Cenozoic sediments and (or) in the sediments of the Potomac-Raritan-Magothy aquifer system where they subcrop or crop out. The estimated transmissivity throughout most of the unconfined area is between 1,000 and $7,000 \mathrm{ft}^{2} / \mathrm{d}$. Lateral variations in the transmissivity result primarily from changes in the combined thickness of the upper Cenozoic deposits and the underlying sediments of the Potomac-Raritan-Magothy aquifer system.

The transmissivity of the confined part of the upper aquifer of the Potomac-RaritanMagothy aquifer system (fig. 20) generally ranges from 1,000 to $10,000 \mathrm{ft}^{2} / \mathrm{d}$. Lateral variations in transmissivity in the upper aquifer reflect changes in both aquifer hydraulic conductivity and aquifer thickness. The horizontal hydraulic conductivity of the upper aquifer is $75 \mathrm{ft} / \mathrm{d}$ throughout 


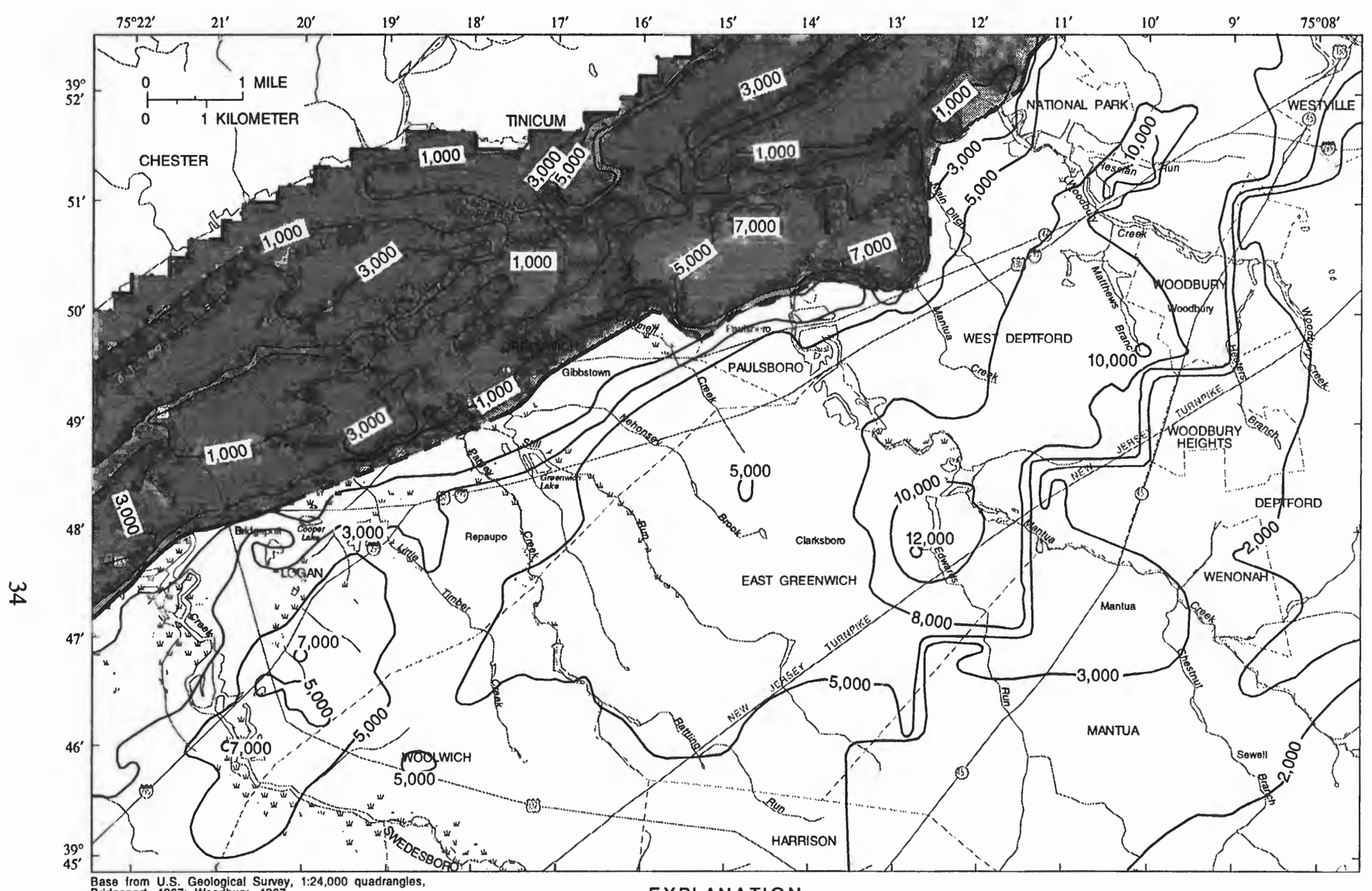

Base from U.S. Geological Sunvey, 1:24,000 quadrangles,
Bridgeport, 1967; Woodbury, 1967

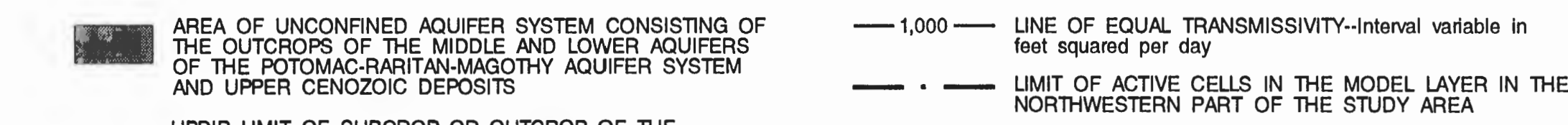
OF THE POTOMAC-RARITAN-MAGOTHY AQUIFER SYSTEM OENOZOIC DEPOSITS

UPPER AQUIFER OF THE POTOMAC-RARITAN-MAGOTHY AQUIFER SYSTEM--Contact is dashed where extent is approximate

Figure 20. Transmissivity of the upper aquifer of the Potomac-Raritan-Magothy aquifer system (model layer 1), and in the unconfined area, transmissivity includes the middle and lower aquifers of the Potomac-Raritan-Magothy aquifer system (model lavers 1 through 4) and overlying upper Cenozoic deposits in the Greenwich Township. New Jersev. studv area. 


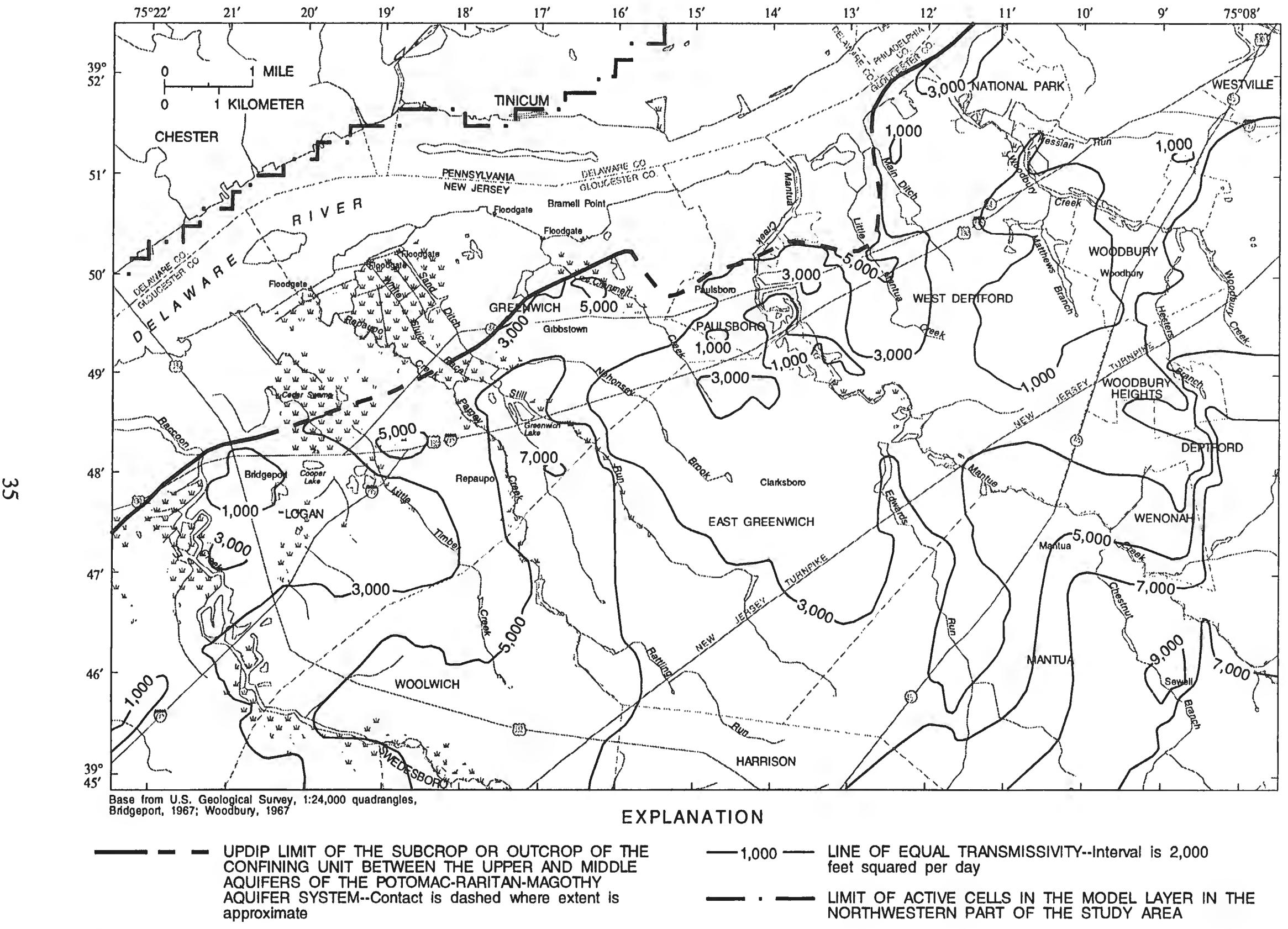

Figure 21. Transmissivity in the confined area of the upper part of the middle aquifer of the Potomac-Raritan-Magothy aquifer system (model layer 2) in the Greenwich Township, New Jersey, study area. 


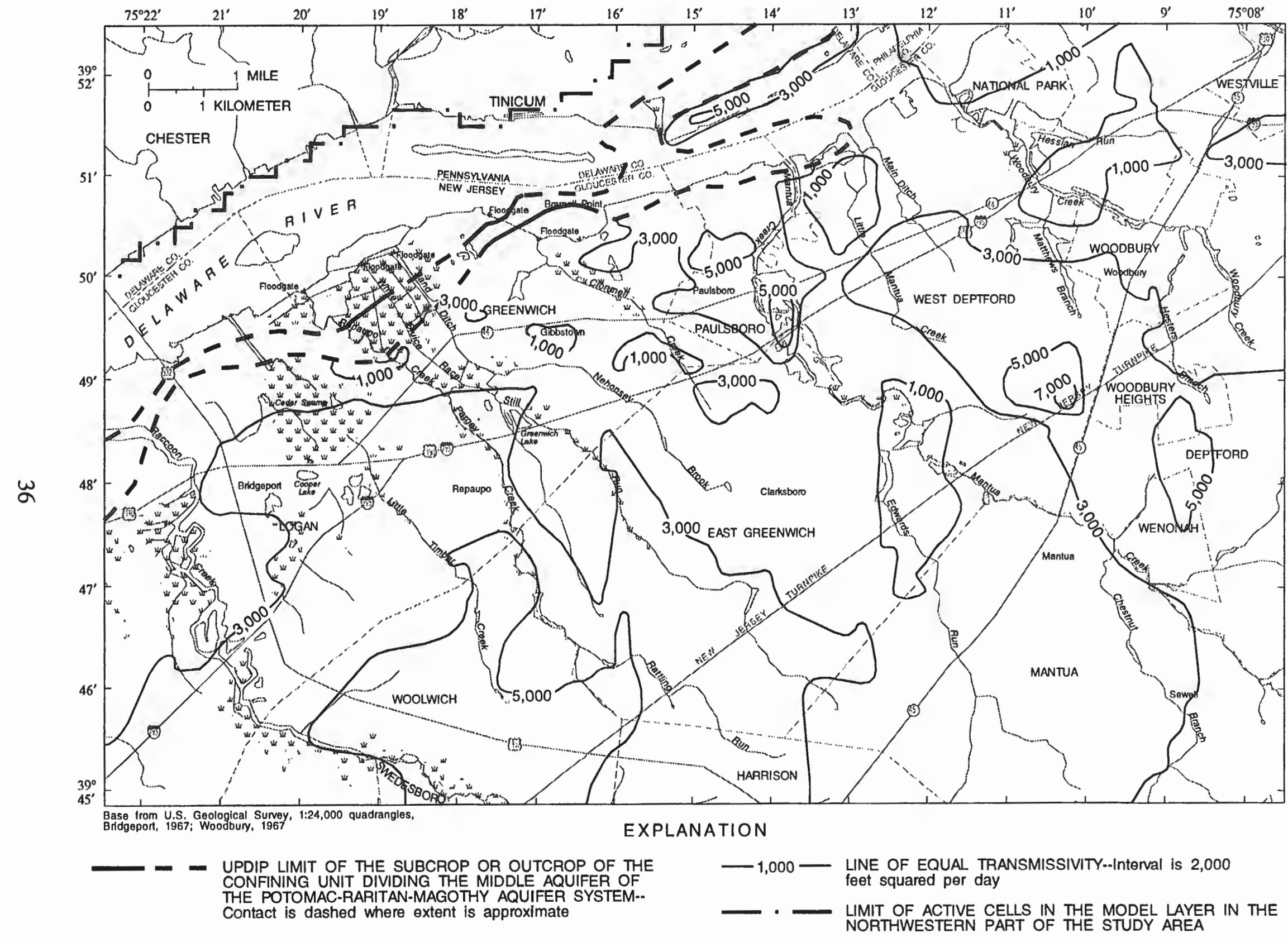

Figure 22. Transmissivity in the confined area of the lower part of the middle aquifer of the Potomac-Raritan-Magothy aquifer system (model layer 3 ) in the Greenwich Township, New Jersey, study area. 


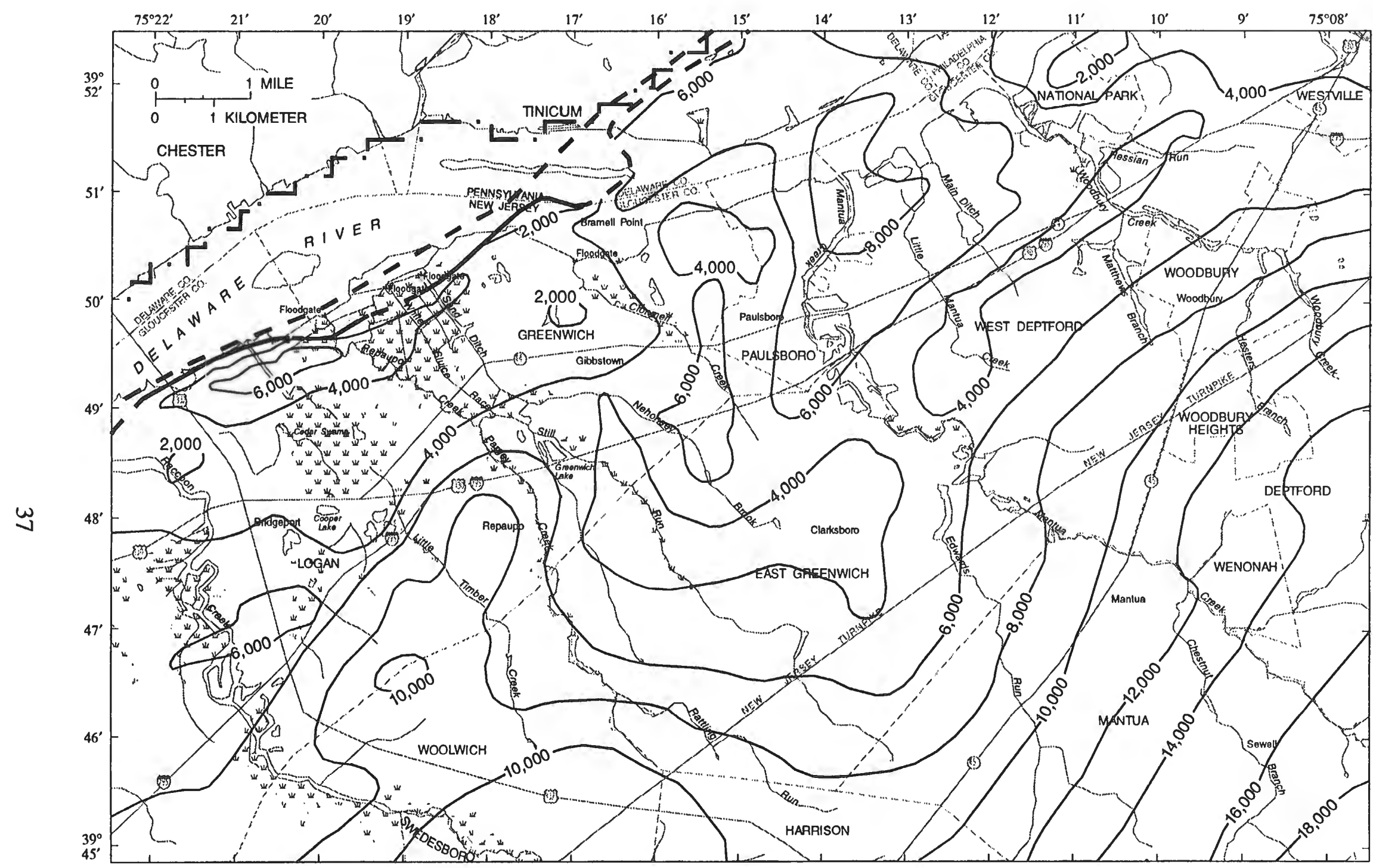

Base Irom U.S. Geological Survey, 1:24,000 quadrangles, - - UPDIP LIMIT OF THE SUBCROP OR OUTCROP OF THE $\quad-1,000-$ LINE OF EQUAL TRANSMISSIVITY--Interval is 2,000 CONFINING UNIT BETWEEN THE MIDDLE AND LOWER AQUIFERS OF THE POTOMAC-RARITAN-MAGOTHY

AQUIFER SYSTEM--Contact is dashed where extent is
approximate

Figure 23. Transmissivity in the confined area of the lower aquifer of the Potomac-Raritan-Magothy aquifer system (model layer 4) in the Greenwich Township, New Jersey, study area. 
most of the modeled area, except in the southeastern part, where it is $30 \mathrm{ft} / \mathrm{d}$. These values are less than the median hydraulic conductivity, $122 \mathrm{ft} / \mathrm{d}$, computed for the aquifer from specificcapacity data for 22 wells in the study area (Barton and Kozinski, 1991, table 6). Hydraulic conductivities computed from results of specific-capacity tests are expected to be higher than model values because specific-capacity measurements commonly are made on wells screened in the parts of aquifers that have the highest yields.

Transmissivity of the upper part of the middle aquifer (model layer 2) is shown in figure 21. The values generally range from 1,000 to $9,000 \mathrm{ft}^{2} / \mathrm{d}$. Transmissivity generally increases with aquifer thickness toward the southeast. The transmissivity of the lower part of the middle aquifer (model layer 3) is shown in figure 22 and generally ranges from 1,000 to $7,000 \mathrm{ft}^{2} / \mathrm{d}$. To estimate the total transmissivity in the areas where the upper and lower parts of the middle aquifer are undifferentiated (fig. 7), the values shown in figures 21 and 22 can be added. In these undifferentiated areas, the highest transmissivities are approximately $12,000 \mathrm{ft}^{2} / \mathrm{d}$ in the area of Mantua and Deptford Townships. Barton and Kozinski (1991) estimate an average transmissivity of $10,788 \mathrm{ft}^{2} / \mathrm{d}$ for the combined middle aquifer. Another estimate of the transmissivity of the middle aquifer, determined from a regional ground-water-flow model of the New Jersey Coastal Plain (Martin, in press, fig. 56), ranges from 2,000 to $9,000 \mathrm{ft}^{2} / \mathrm{d}$.

The horizontal hydraulic conductivity of the upper and lower parts of the middle aquifer is equal to $75 \mathrm{ft} / \mathrm{d}$ throughout the study area, except in the lower part of the middle aquifer in the southeastern part of the modeled area, where it is $40 \mathrm{ft} / \mathrm{d}$. Barton and Kozinski (1991, table 6) report a median hydraulic conductivity of $124 \mathrm{ft} / \mathrm{d}$ computed from specific-capacity data for 29 wells screened in the middle aquifer. The discrepancy between these calibrated and computed hydraulic conductivities again can be explained by the tendency for hydraulic conductivities calculated from results of specific-capacity tests to be high.

Transmissivity of the lower aquifer (model layer 4) is shown in figure 23, and generally ranges from 2,000 to $18,000 \mathrm{ft}^{2} / \mathrm{d}$. The highest transmissivity is in southeastern Mantua Township; the lowest is in Logan Township, near the Delaware River. Barton and Kozinski (1991) estimate the average transmissivity of the lower aquifer from results of specific-capacity tests to be $12,940 \mathrm{ft}^{2} / \mathrm{d}$. Martin (in press, fig. 55) reports that the transmissivity of the lower aquifer in the Greenwich Township study area ranges from 6,000 to $10,000 \mathrm{ft}^{2} / \mathrm{d}$. The horizontal hydraulic conductivity of the lower aquifer is $75 \mathrm{ft} / \mathrm{d}$ throughout the study area; this value is lower than the median hydraulic conductivity of $132 \mathrm{ft} / \mathrm{d}$ computed by Barton and Kozinski (1991, table 6) from specific-capacity data for 35 wells in the lower aquifer. The hydraulic conductivities estimated in this analysis are consistent with hydraulic conductivities that resulted from a simulation of ground-water flow in the Camden area, which includes the Greenwich Township study area (Navoy and Carleton, 1995).

\section{Confining-Unit Leakance}

Leakance is a measure of the vertical water-transmitting properties of aquifer and confining-unit material that affect flow between model layers. It represents the vertical hydraulic conductance per unit area of a model grid cell and is calculated by dividing the vertical hydraulic conductivity by the thickness of material through which the water flows from layer to layer. In areas where no confining unit is present, the leakance is calculated from the vertical hydraulic conductivity of the aquifer material and half the thickness of each layer. If a confining unit is present, the leakance value is dominated by that unit; therefore, leakance is calculated from the vertical hydraulic conductivity of the confining layer and its thickness. 
The vertical hydraulic conductivity of all aquifer material was assumed to be one-tenth of the horizontal hydraulic conductivity. Initial estimates of confining-unit vertical hydraulic conductivity were made from permeability tests of cores (Barton and Kozinski, 1991, table 4); initial values generally were lower than calibrated-model values, probably because permeability tests were conducted on cores from clay-rich zones of the confining units. Leakances used in the model for each confining unit are shown in figures 24-27.

The leakance of the Merchantville-Woodbury confining unit is shown in figure 24. Previous studies (Zapecza, 1989, p. B12; Barksdale and others, 1958, p. 136) report that this confining unit has a vertical hydraulic conductivity value that is at least several orders of magnitude lower than that of adjacent aquifers. The confining unit's leakance generally varies from $5 \times 10^{-6}$ to less than $5 \times 10^{-7} \mathrm{~d}^{-1}$. The value decreases to the southeast because thickness increases in the downdip direction and because the vertical hydraulic conductivity is lower in the southeastern part of the study area than in the northwestern part. The leakance is highest (greater than $5 \times 10^{-6} \mathrm{~d}^{-1}$ ) near the outcrop, where the confining unit is thinnest. The leakance of the Merchantville-Woodbury confining unit within the Greenwich Township study area was estimated by Martin (in press, fig. 67) to range from $1 \times 10^{-6}$ to $5 \times 10^{-7} \mathrm{~d}^{-1}$.

The calibrated leakances of the confining unit between the upper and middle aquifers are shown in figure 25 . For most of the confining unit's extent, leakance varies from $5 \times 10^{-4}$ to less than $5 \times 10^{-5} \mathrm{~d}^{-1}$, generally decreasing as the confining unit thickens downdip. The leakance is highest (greater than $1 \times 10^{-3} \mathrm{~d}^{-1}$ ) near the outcrop, where the confining unit is thinnest. Martin (in press, fig. 66) presents values of leakance for this confining unit that range from about $5 \times 10^{-4}$ to $5 \times 10^{-6} \mathrm{~d}^{-1}$ within the study area.

The calibrated leakance of the confining unit dividing the middle aquifer is shown in figure 26. Barton and Kozinski (1991) report that aquifer-test results and differences in water quality and ground-water levels in aquifers above and below this confining unit indicate that the unit is effective in limiting ground-water flow. The confining unit has a lobate shape and pinches out in some downdip areas. For most of the confining unit's extent, leakance ranges from $1 \times 10^{-3}$ to less than $5 \times 10^{-4} \mathrm{~d}^{-1}$. Lateral variation in leakance is caused primarily by variations in confining-unit thickness. The confining unit that divides the middle aquifer has not been analyzed in previous modeling investigations.

The calibrated leakance of the confining unit between the middle and lower aquifers is shown in figure 27. On the basis of aquifer-test results and an analysis of differences in water levels and water quality between the middle and lower aquifers, Barton and Kozinski (1991) report that the confining unit effectively impedes vertical flow. Its leakance ranges from $5 \times 10^{-4}$ to less than $5 \times 10^{-5} \mathrm{~d}^{-1}$. Lateral variations are caused by variations in confining-unit thickness and vertical hydraulic conductivities. Confining-unit leakance within the Greenwich Township study area reported by Martin (in press, fig. 65) ranges from more than $1 \times 10^{-4}$ to $5 \times 10^{-5} \mathrm{~d}^{-1}$.

The Wissahickon Formation underlies the Potomac-Raritan-Magothy aquifer system throughout the study area. In its unweathered state, the Wissahickon Formation is relatively impermeable to water (Barksdale and others, 1958, p. 73). This unit has not been developed as a water source in the area (Barton and Kozinski, 1991) and is represented in the model as an impermeable boundary.

\section{Simulation of Recent (1986 Conditions}

Results of a ground-water-flow simulation of recent (1986) conditions in the Greenwich Township study area is presented in the following sections. The results are in the form of simulated distribution of hydraulic head and ground-water flow within the ground-water system. 


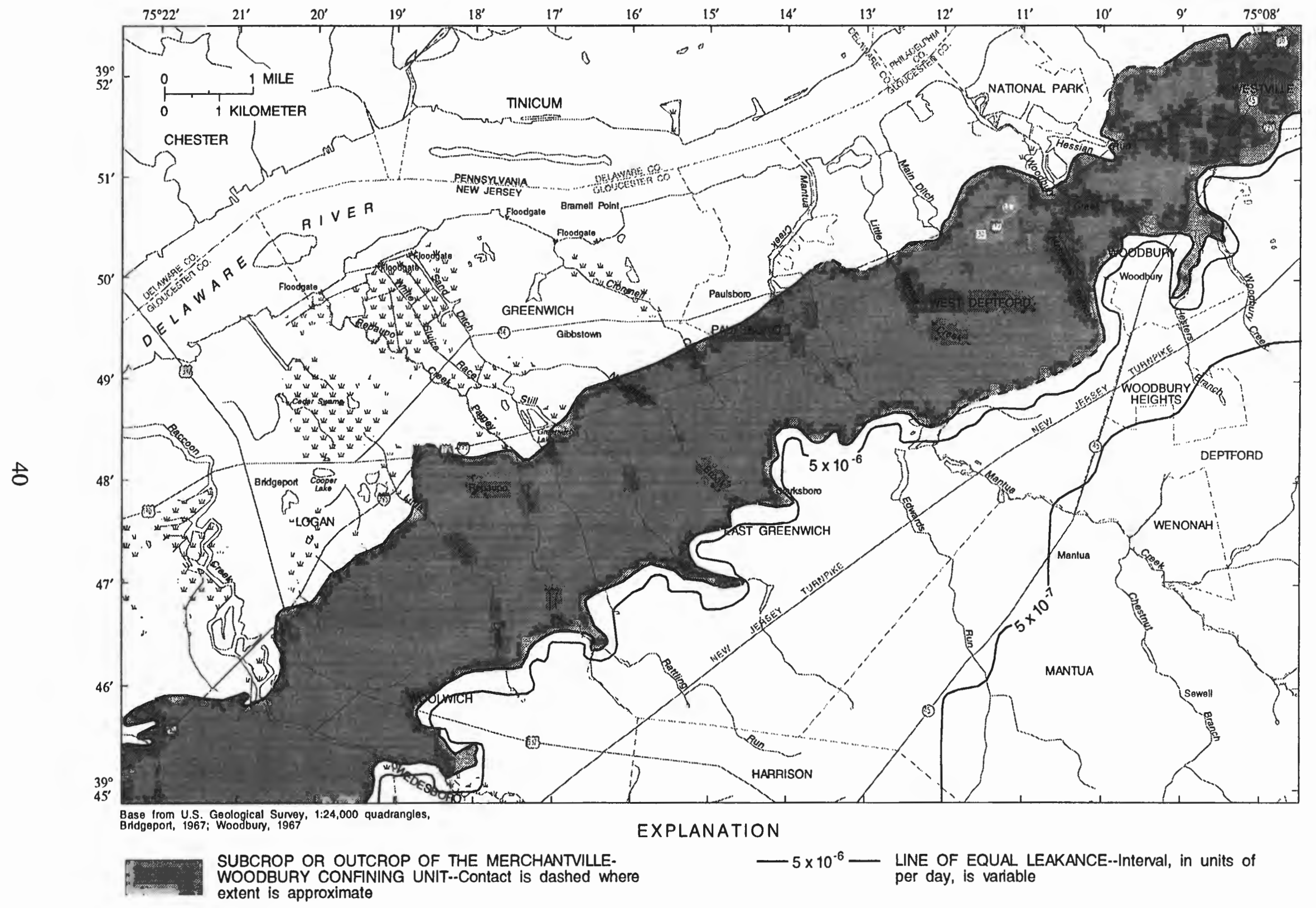

Figure 24. Leakance of the Merchantville-Woodbury confining unit in the Greenwich Township, New Jersey, study area. 


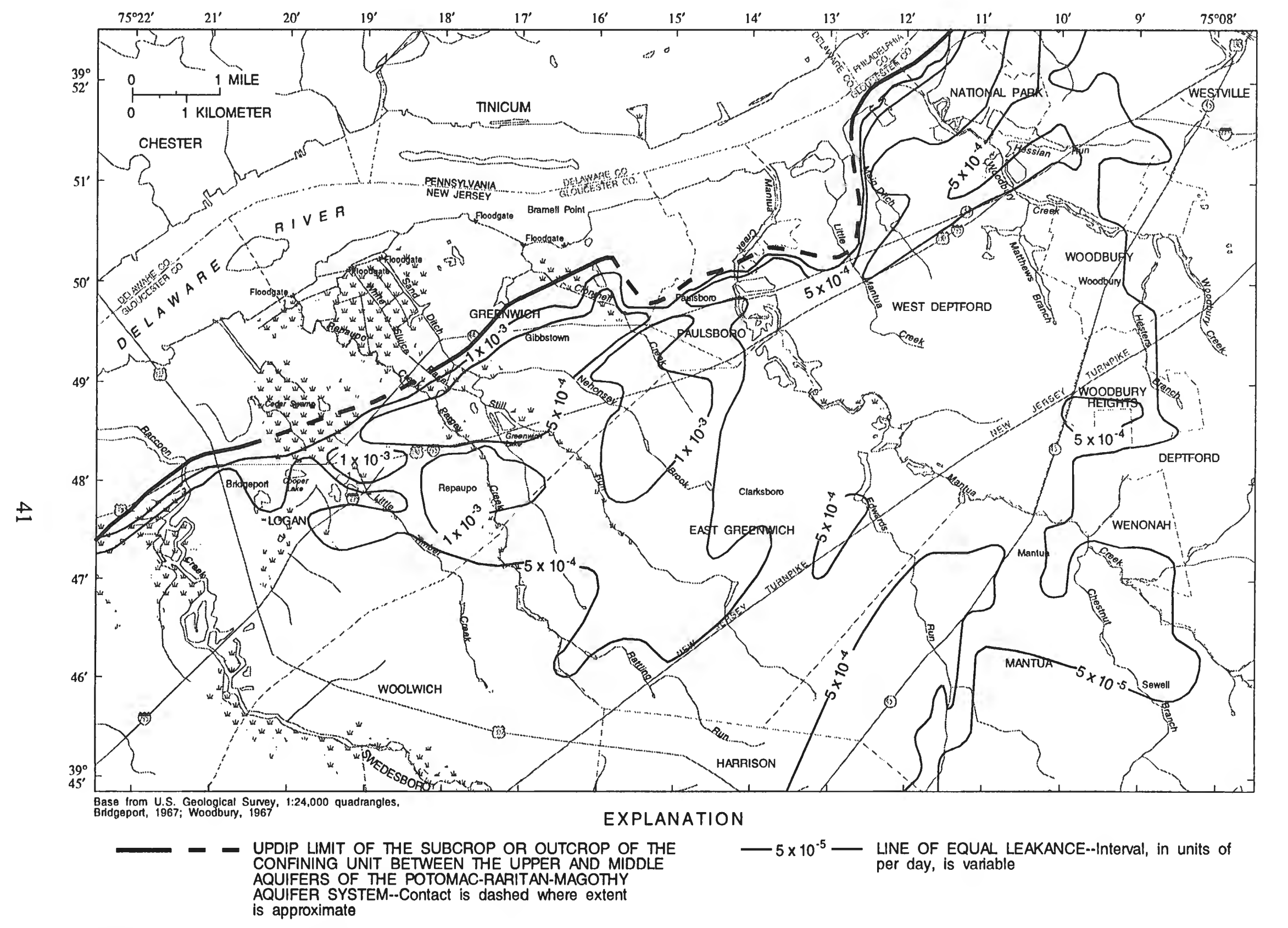

Figure 25. Leakance of the confining unit between the upper and middle aquifers of the Potomac-Raritan-Magothy aquifer system in the Greenwich Township, New Jersey, study area. 


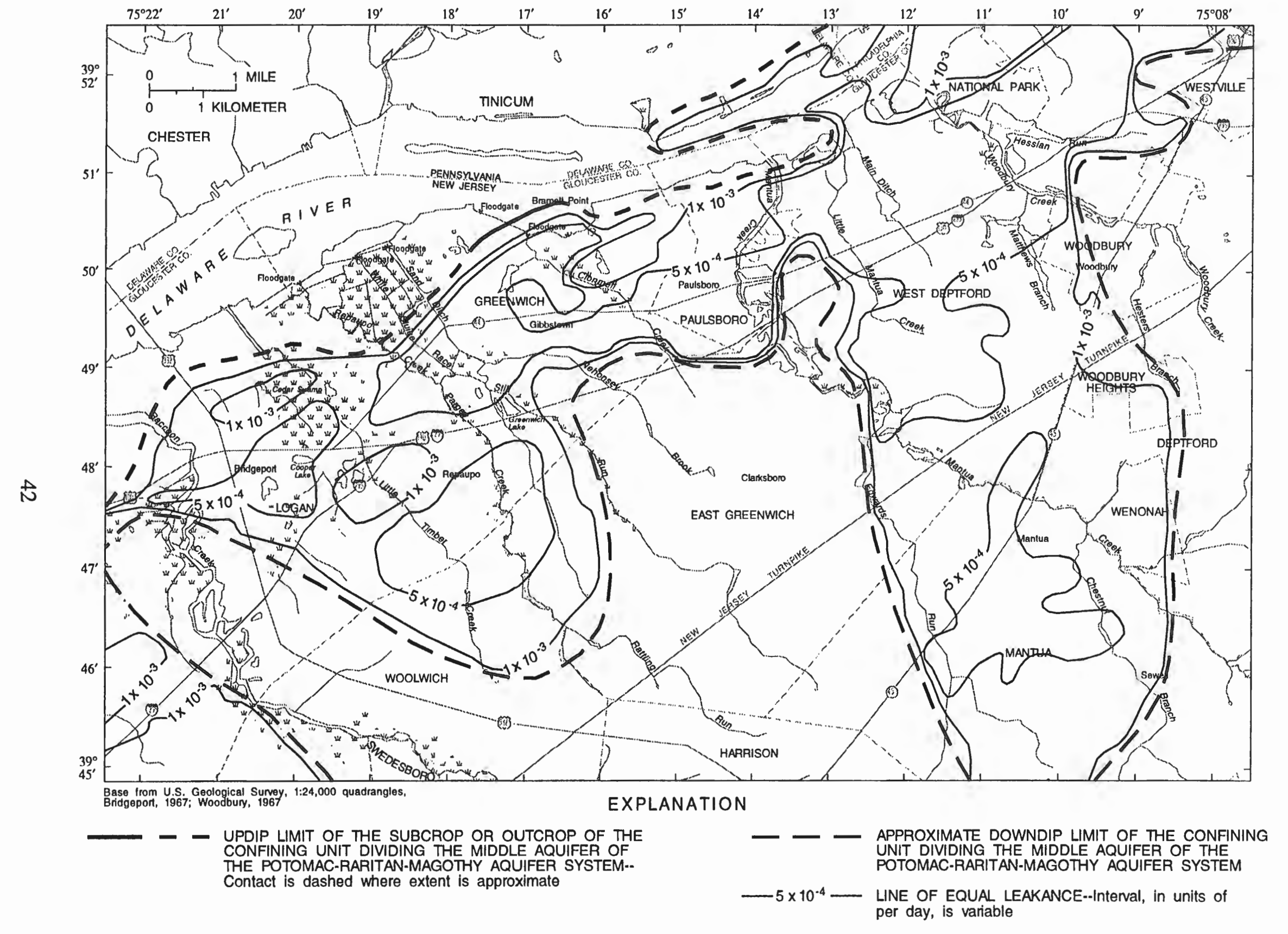

Figure 26. Leakance of the confining unit dividing the middle aquifer of the Potomac-Raritan-Magothy aquifer system in the Greenwich Township, New Jersey, study area. 


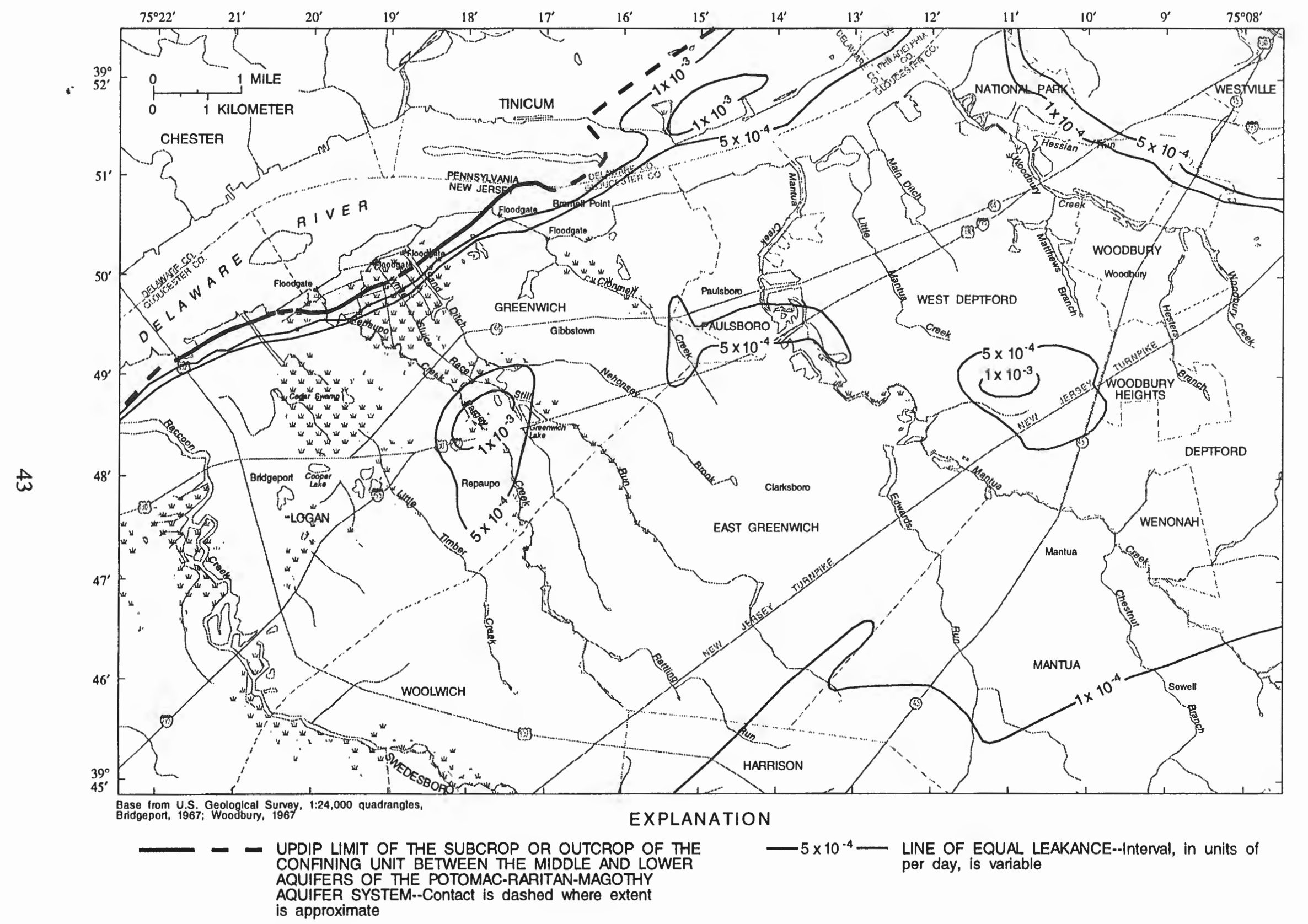

Figure 27. Leakance of the confining unit between the middle and lower aquifers of the Potomac-Raritan-Magothy aquifer system in the Greenwich Township, New Jersey, study area. 
Head distributions are presented as a map of the potentiometric surface of each aquifer and include the potentiometric-surface map interpreted from data measured in August and September 1986. Head results are presented in this manner so that (1) the pattern and distribution of groundwater flow and the related effects of development can be evaluated, and (2) the simulated results can be compared to measured data, thereby enabling an assessment of the correspondence between the model and the actual ground-water system. The distribution of ground-water flow is presented as a budget that defines the quantity of ground-water flow that recharges and (or) discharges to each aquifer and boundary.

\section{Ground-Water Levels and Flow Patterns}

Simulated ground-water levels and water levels measured during August and September 1986 in each aquifer of the Potomac-Raritan-Magothy aquifer system are shown in figures 28-31. The water table, which occurs either in upper Cenozoic deposits or the outcrop of PotomacRaritan-Magothy sediments, is included in figure 28. The potentiometric surface interpreted from measured values was modified from Barton and Kozinski (1991) on the basis of hydrologic insights gained during this modeling analysis.

Of the 79 observation wells in the study area, 29 are screened in the upper aquifer; 14 are screened in the upper, or undifferentiated part of the middle aquifer; 20 are screened in the lower, or undifferentiated part of the middle aquifer; and 16 are screened in the lower aquifer. Many of these observation wells are in or near the outcrop or subcrops of the aquifers which, along with upper Cenozoic sediments, are interpreted as being unconfined (fig. 18).

Ground-water levels in all aquifers ranged from near sea level in the unconfined area to more than $50 \mathrm{ft}$ below sea level in the southeastern part of the Greenwich Township study area. The altitude of the potentiometric surface of each aquifer decreased southeastward with a hydraulic gradient ranging from 3 to $15 \mathrm{ft} / \mathrm{mi}$. The potentiometric surfaces of the aquifers have generally the same configuration despite the fact that confining-unit leakances are relatively low, because they have similar distributions of ground-water sources and sinks; a large regional cone of depression in the eastern part of the modeled area is a feature common to each aquifer that results from the presence of regional withdrawal centers to the east, outside the study area (Eckel and Walker, 1986; Barton and Kozinski, 1991).

The unconfined aquifer system represents a composite of the subcrops of all four aquifers, plus the overlying upper Cenozoic deposits (fig. 18). The unconfined aquifer system is separated from the confined potentiometric surface of the upper aquifer by the updip limit of the Merchantville-Woodbury confining unit. The water table never attains an altitude of more than a few feet above sea level in interstream areas. The water table is depressed by significant pumping between Greenwich and Paulsboro and by wetlands maintained below sea level by tide gates.

Unconfined areas where heads are above sea level primarily are recharge areas, as in the southwestern (in Logan Township) and northern parts (West Deptford Township and National Park Borough) of the study area. The water table indicates flow toward surface-water bodies-especially Repaupo Creek, White Sluice Race, Sand Ditch, and Clonmell Creek in Greenwich Township, where heads are held below sea level by floodgates. These streams and the wetlands near them are simulated as gaining flow from aquifers. Elsewhere, especially in the northeastern part of Greenwich Township where several industrial chemical spills and leaks are being contained by wells, streams have proportionately more losing reaches.

The potentiometric surface of the confined upper aquifer reflects the large regional cone of depression near the southeastern border of the study area. Heads range from near sea level at the pinchout of the Merchantville-Woodbury confining unit to about $70 \mathrm{ft}$ below sea level at the 
southeastern corner of the study area. The potentiometric surface indicates that recharge in the unconfined area and induced inflow from the Delaware River and its tributary streams are being diverted to the regional pumping center to the southeast. A small area of inward flow across the eastern lateral boundary is the result of withdrawals from wells 15-6 and 15-187 located very near to the model boundary (fig. 28).

The simulated and interpreted 1986 potentiometric-surface contours for the confined upper aquifer generally are in agreement. Simulated heads are within $10 \mathrm{ft}$ of measured heads everywhere except possibly in well 15-6 in Deptford Township. However, this well is pumped intermittently and measurements are made during recovery.

Vertical head differences between the upper aquifer and the overlying Englishtown aquifer system indicate leakage downward from the Englishtown aquifer system into the upper aquifer. Simulated water levels in the Englishtown aquifer system are much higher than those simulated in the upper aquifer; measured heads are as much as $90 \mathrm{ft}$ higher in the Englishtown aquifer system than in the upper aquifer in Deptford Township.

An interpreted potentiometric surface is not provided for the upper part of the middle aquifer because available water-level measurements were insufficient. Simulated heads are within a few feet of most measured water levels and within $10 \mathrm{ft}$ of all measured water levels. The simulated potentiometric surface in the upper part of the middle aquifer (fig. 29) indicates that the primary area of ground-water recharge is near the outcrop and subcrop of the aquifer. Water levels range from about sea level near the outcrop and subcrop of the upper part of the middle aquifer to more than $50 \mathrm{ft}$ below sea level in Deptford and Mantua Townships. Lateral ground-water flow is generally southeastward, toward the major withdrawal centers and a cone of depression centered in southeastern Gloucester County and in Camden County (Eckel and Walker, 1986). West Deptford Township production well 15-435 (screened in both the upper and middle parts of the middle aquifer) locally diverts regional flow toward an isolated cone of depression centered in southeastern West Deptford Township. The major lateral flow was simulated as discharge out of the modeled area along the southern and eastern boundaries.

The heads in the upper part of the middle aquifer are as much as $20 \mathrm{ft}$ greater than those in the upper aquifer in the downdip area near Mantua and Deptford Townships. Therefore, leakage in this area was upward into the upper aquifer.

Simulated and interpreted heads in the lower part of the middle aquifer are shown in figure 30. Simulated heads were within a few feet of most, and within $10 \mathrm{ft}$ of all, measured water levels. The potentiometric surface indicates that the unconfined area of the aquifer near the Delaware River is a major source of ground-water recharge. The altitude of the potentiometric surface in the lower part of the middle aquifer ranges from about sea level near the aquifer's subcrop to more than $50 \mathrm{ft}$ below sea level in Deptford and Mantua Townships. The shape of the potentiometric surface indicates that lateral ground-water flow in the middle aquifer is toward the southeast, where major withdrawals are centered in southeastern Gloucester County and in Camden County (Eckel and Walker, 1986). A local depression in the potentiometric surface is caused by large withdrawals from several wells in updip areas that are screened either in the lower part of the middle aquifer or in undifferentiated parts of the middle aquifer in Greenwich Township and in Paulsboro Borough. In these areas, the simulated potentiometric surface probably indicates local flow directions better than does the interpreted potentiometric surface, which is constrained by a limited distribution of water-level data. Isolated cones of depression in downdip areas were simulated around major production wells in southeastern West Deptford Township (West Deptford Township production well 15-435) and in Woodbury Borough (Woodbury Water Department production well 15-431) (fig. 30). 


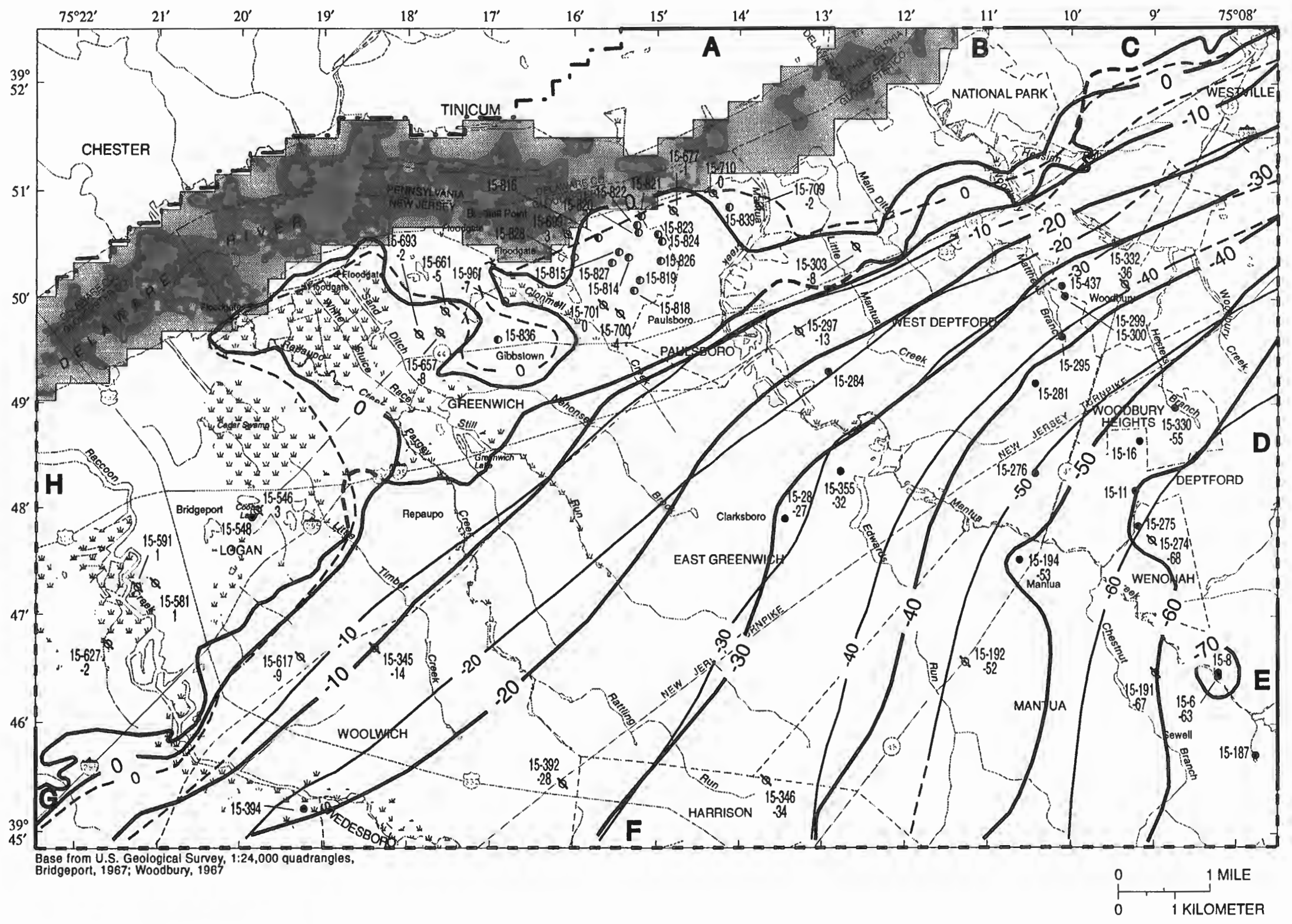


CONSTANT-HEAD BOUNDARY REPRESENTING THE

DELAWARE RIVER

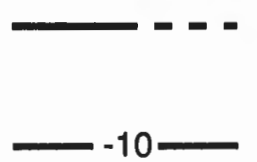

UPDIP LIMIT OF SUBCROP OR OUTCROP OF THE MERCHANTVILLE-WOODBURY CONFINING

UNIT.-Contact is dashed where oxtent is approximate

SIMULATED POTENTIOMETRIC CONTOUR--Shows altitude of simulated potentiometric surface and water table for 1986. Contour interval is 10 feet. Datum is sea level

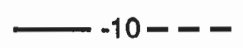

INTERPRETED POTENTIOMETRIC CONTOUR--Shows altitude of interpreted potentiometric surface and water table for 1986. Contours are modified from Barton and Kozinski (1991). Contour interval is 10 feet. Dashed where approximate. Datum is sea level

- - - - LIMIT OF ActIVE MODEL CELLS IN THIS LAYER

- - - - - _ - SEGMENT OF BOUNDARY WHERE FLOW IS OUT OF MODEL AREA--Magnitude of flow listed in the accompanying table

SEGMENT OF BOUNDARY WHERE FLOW IS INTO MODEL

AREA--Magnitude of flow listed in the accompanying table
15-297 OBSERVATION WELL.-Upper number is well number consisting

of two-digit county code followed by three-digit sequence number.

Well screened in the upper aquifer. Lower number is altitude of

measured water level, in feet. Date of measurement is AugustSeptember 1986. From Barton and Kozinski (1991, table 8). Datum is sea level

- 15-28 WITHDRAWAL WELL--Upper number is well number consisting of two-digit county code followed by three-digit sequence number Well screened in the upper aquiler. Lower number is altude of September 1986. From Barton and Kozinski (1991, table 8). Datum is sea level

15-281 WITHDRAWAL WELL--Well number consists of two-digit county code followed by three-digit sequence number. Well screened in the upper aquifer

15-828 WITHDRAWAL WELL--Well number consists of two-digit county code followed by three-digit sequence number. Well screened in the undifferentiated Quaternary deposits

\section{LATERAL FLOWS FOR BOUNDARY SEGMENTS}

[Flows in million gallons per day; lettered boundary segments shown in figure; negative value
indicates flow is out of model area]

\begin{tabular}{cr} 
Segment & Flow \\
\hline A & 0.031 \\
B & -0.069 \\
C & 0.734 \\
D & -0.964 \\
E & 0.263 \\
F & -1.542 \\
G & 0.145 \\
H & -0.071
\end{tabular}

Figure 28. Simulated and interpreted potentiometric surface in the upper aquifer of the Potomac-Raritan-Magothy aquifer system and the water table in the outcrop/subcrop area in the Greenwich Township, New Jersey, study area under recent (1986) stressed conditions. 


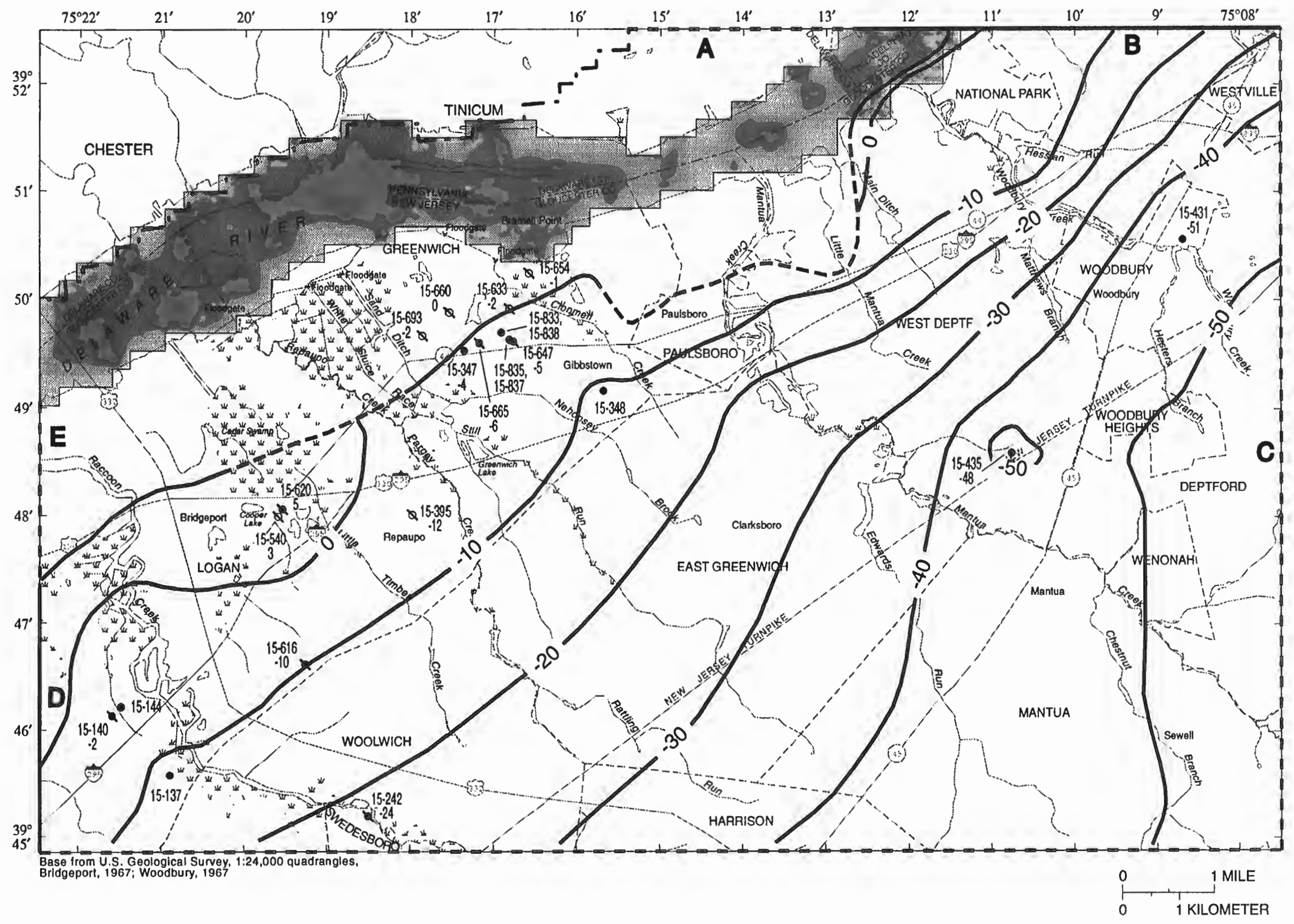




\section{EXPLANATION}

CONSTANT-HEAD BOUNDARY REPRESENTING THE DELAWARE RIVER

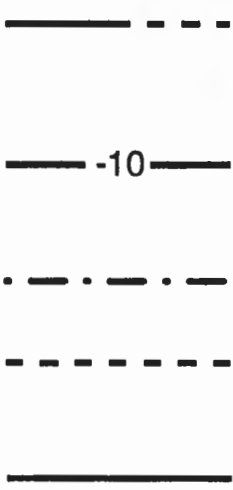

UPDIP LIMIT OF SUBCROP OR OUTCROP OF THE CONFINING UNIT BETWEEN THE UPPER AND MIDDLE SYSTEM-Contact is dashed whe where extent is approximate

SIMULATED POTENTIOMETRIC CONTOUR--Shows altitude of simulated potentiometrlc surface and water table for 1986. Contour interval is 10 feet. Datum is sea level

作

SEGEMENT OF BOUNDARY WHERE FLOW IS OUT OF MODEL AREA--Magnitude of flow listed in the accompanying

SEGMENT OF BOUNDARY WHERE FLOW IS INTO MODEL AREA--Magnitude of flow listed in the accompanying table
Q ${ }^{15-693}$ OBSERVATION WELL--Upper number is well number consisting of two-digit county code followed by three-digit sequence number. Well screened in the upper part of the middle aquifer. Lower number is altitude of measured water level, in feet. Date of measurement is August-September 1986. From Barton and Kozinski (1991, table 8). Datum is sea level

15-620 OBSERVATION WELL--Upper number is well number consisting of two-digit county code followed by three-digit sequence number. Well screened in the undifferentiated part, or both upper and lower parts, of the middle aquifer. Lower number is altitude of measured 1986. From Barton and Kozinski (1991, table 8). Datum is sea level

- 15-435 WITHDRAWAL WELL--Upper number is well number consisting of two-digit county code followed by three-digit sequence number. ened in the undifferentiated part, or both the upper and lower parts, of the middie aquifer. Lower number is altitude of measured water From Barton and Kozinski (1991, tablo 8). Datum is sea level

15-348 WITHDRAWAL WELL--Well number consists of two-digit county code followed by three-digit sequence number. Well screened in the undifferentiated part, or both the upper and lower parts, of the middle aquifer

LATERAL FLOWS FOR BOUNDARY SEGMENTS

[Flows in million gallons per day; lettered boundary segments shown in figure; negative value indicates flow is out of model area]

\begin{tabular}{cc} 
Segment & Flow \\
\hline A & -0.033 \\
B & 0.643 \\
C & -2.819 \\
D & 0.172 \\
E & -0.043
\end{tabular}

Figure 29. Simulated potentiometric surface in the upper part of the middle aquifer of the Potomac-Raritan-Magothy aquifer system in the Greenwich Township, New Jersey, study area under recent (1986) conditions. 


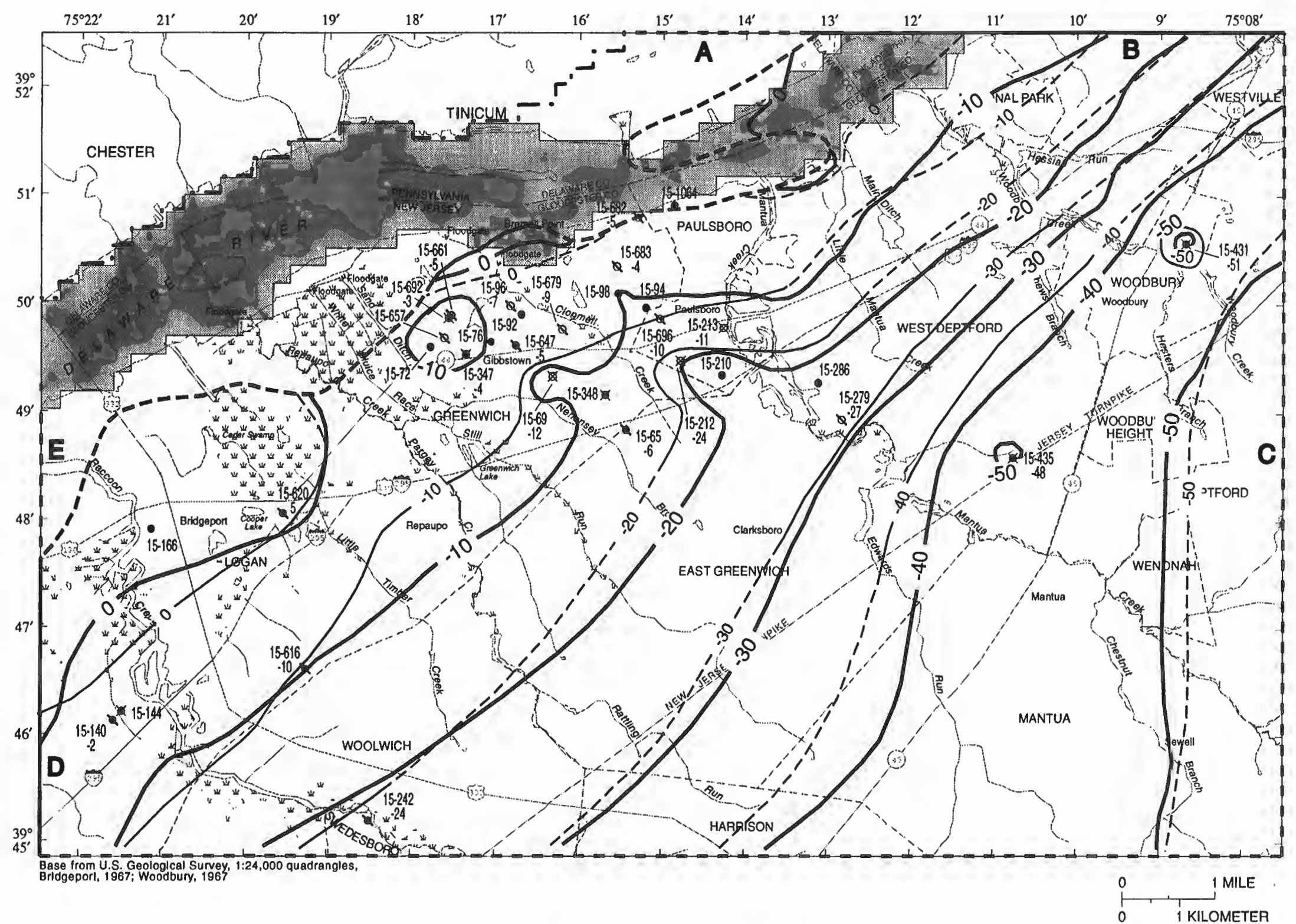



CONSTANT-HEAD BOUNDARY REPRESENTING THE
DELAWARE RIVER

UPDIP LIMIT OF SUBCROP OR OUTCROP OF THE CONFINING UNIT DIVIDING THE MIDDLE AQUIFER OF THE POTOMAC-RARITAN-MAGOTHY AQUIFER

SYSTEM--Contact is dashed where extent is approximate

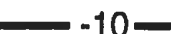

SIMULATED POTENTIOMETRIC CONTOUR--Shows altitude of simulated potentiometric surface and water table for 1986. Contour interval is 10 feet. Datum is sea leve

10- - - INTERPRETED POTENTIOMETRIC CONTOUR--Shows altitude of interpreted potentlometric surface and water table for 1986. Contours are modified from Barton and Kozinski (1991). Contour Interval Is 10 feet. Dashed where approximate. Datum is sea leve

- - - L LIMIT OF ACTIVE MODEL CELLS IN THIS LAYER

SEGEMENT OF BOUNDARY WHERE FLOW IS OUT OF MODEL AREA--Magnitude of flow listed in the accompanying table

SEGMENT OF BOUNDARY WHERE FLOW IS INTO MODEL AREA--Magnitude of flow listed in the accompanying table
$Q_{-4}^{15-683}$ OBSERVATION WELL--Upper number is well number consisting Well digit county code followed by three-diglt sequence number. Well screen co in the lower part of is altude of measured water level, in feet. Date of measurement is Datum is sea level

15-647 OBSERVATION WELL--Upper number is well number consisting of two-digit county code followed by three-digit sequence numbe Well screened in the undifferentiated part of the middle aquifer. Lower number is altitude of measured water level, in feet. Date of measurement is August-September 1986. From Barton and Kozinski (1991, table 8). Datum is sea level

15-213 WITHDRAWAL WELL--Upper number is well number consisting of two-digit county code followed by three-digit sequence number. Well screened in the lower part of the middle aquifer. Lower number is altitude of measured water level, in feet. Date of measurement is August-September 1986. From Barton and Kozinski (1991, table 8). Datum is sea level

15-435 WITHDRAWAL WELL--Upper number is well number consisting
-48 of two-digit county code followed by three-digit sequence number. Well screened in the undifferentiated part, or both the upper and lower parts, of the middle aquifer. Lower number is altitude of measured water level, in feet. Date of measurement is from August to September 1986. From Barton and Kozinski (1991, table 8). Datum is sea level

15-166 WITHDRAWAL WELL--Well number consists of two-digit county code followed by four-digit sequence number. Well screened in the lower part of the middle aquifer

15-144 WITHDRAWAL WELL--Well number consists of two-digit county code followed by three-diglt sequence number. Well screened in the undifferentiated part, or both the upper and lower parts, of the middle aquifer

LATERAL FLOWS FOR BOUNDARY SEGMENTS [Flows in million gallons per day; lettered boundary segments shown in figure; negative value indicates flow is out of model area]

\begin{tabular}{cc} 
Segment & Flow \\
\hline A & -0.298 \\
B & 0.260 \\
C & -1.560 \\
D & 0.194 \\
E & -0.348
\end{tabular}

Figure 30. Simulated and interpreted potentiometric surface in the lower part of the middle aquifer of the Potomac-Raritan-Magothy aquifer system in the Greenwich Township, New Jersey, study area under recent (1986) conditions. 


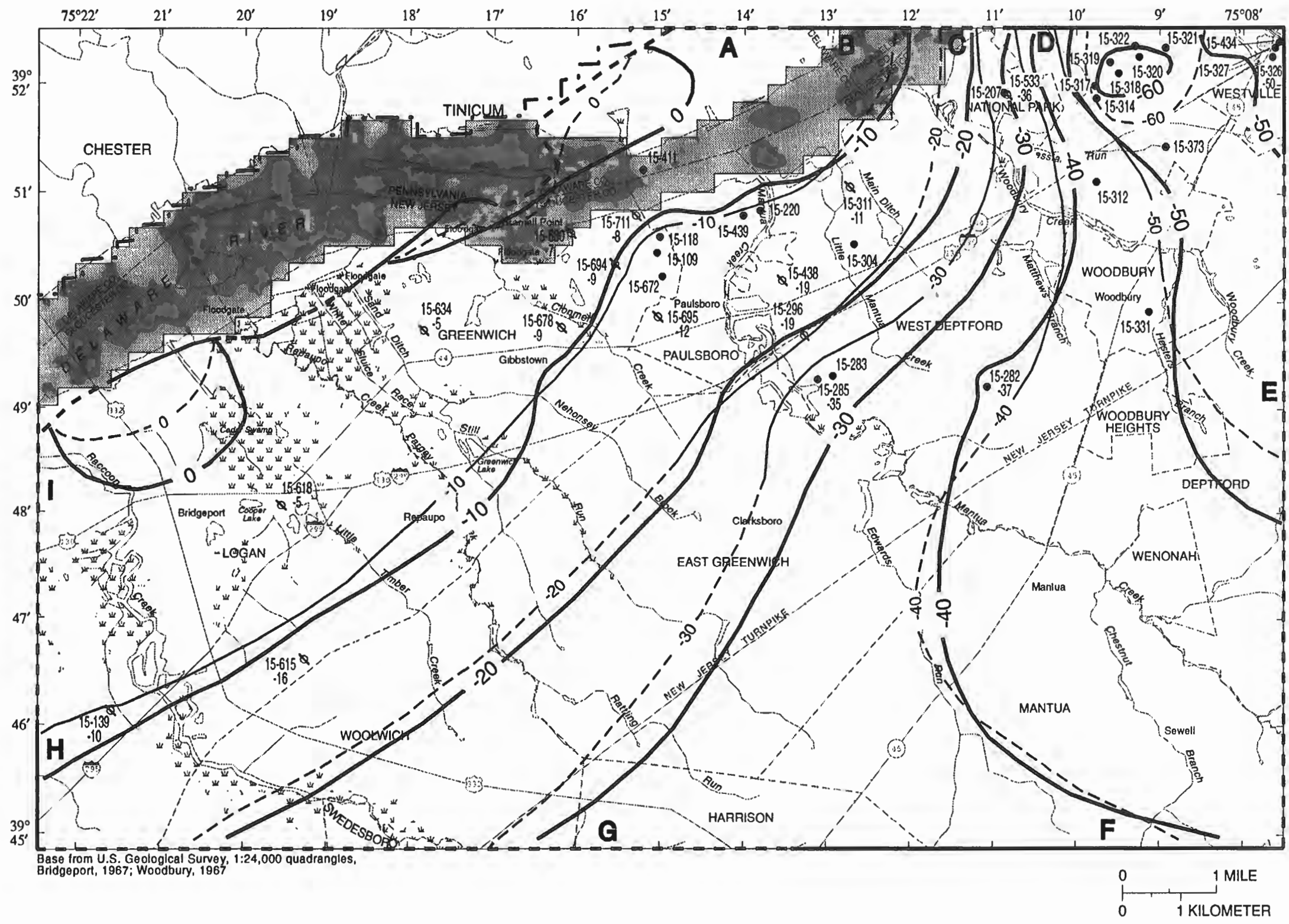




\section{EXPLANATION}

20.7 CONSTANT-HEAD BOUNDARY REPRESENTING THE DELAWARE RIVER

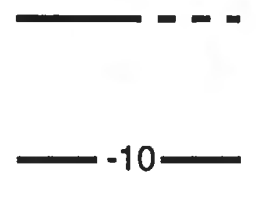

UPDIP LIMIT OF SUBCROP OR OUTCROP OF THE CONFINING UNIT BETWEEN THE MIDDLE AND LOWER AQUIFERS OF THE POTOMAC-RARITAN-MAGOTHY AQUIFER SYSTEM--Contact is dashed where extent is approximate

SIMULATED POTENTIOMETRIC CONTOUR--Shows altitude of simulated potentiometric surface and water table for 1986 Contour interval is 10 feet. Datum is sea level

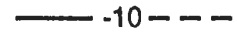

INTERPRETED POTENTIOMETRIC CONTOUR--Shows altitude of interpreted potentiometric surface and water table for 1986. Contours are modified from Barton and Kozinski (1991). Contour interval is 10 feet. Dashed where approxlmate. Datum is sea level

\section{- - - - L LIMIT OF ACTIVE MODEL CELLS IN THIS LAYER}

- _ . - . - SEGEMENT OF BOUNDARY WHERE FLOW IS OUT OF MODEL AREA--Magnitude of flow listed in the accompanylng table

\section{SEGMENT OF BOUNDARY WHERE FLOW IS INTO MODEL} AREA--Magnitude of flow listed in the accompanying table
$Q^{15-618}$ OBSERVATION WELL--Upper number is well number consisting of two-digit county code followed by three-digit sequence number. Well screened in the lower aquifer. Lower number is altitude of measured water level, in feet. Date of measurement is AugustSeptember 1986. From Barton and Kozinski (1991, table 8).

Datum is sea level

- 15-373 WITHDRAWAL WELL--Upper number is well number consisting of two-digit county code followed by three-digit sequence number. Well screened in the lower aquifer. Lower number is altitude of measured water level, in feet. Date of measurement is August September 1986. From Barton and Kozinski (1991, table 8). Datum is sea level

15-304 WITHDRAWAL WELL--Well number consists of two-digit county code followed by three-digit sequence number. Well screened in the lower aquifer

\section{LATERAL FLOWS FOR BOUNDARY SEGMENTS}

[Flows in million gallons per day; lettered boundary segments shown in figure; negative value flow is out of model area]

\begin{tabular}{cc} 
Segment & Flow \\
\hline A & -0.484 \\
B & 0.161 \\
C & -0.308 \\
D & 2.199 \\
E & -2.166 \\
F & 1.714 \\
G & -2.548 \\
H & 0.095 \\
I & -0.340
\end{tabular}

Figure 31. Simulated and interpreted potentiometric surface in the lower aquifer of the Potomac-Raritan-Magothy aquifer system in the Greenwich Township, New Jersey, study area under recent (1986) conditions. 
Heads in the upper part of the middle aquifer generally are $5 \mathrm{ft}$ higher than in the lower part of the middle aquifer in updip areas, and as much as $10 \mathrm{ft}$ higher in the vicinity of Paulsboro Borough, causing downward leakage. Vertical head differences between the upper and lower parts of the middle aquifer are very small in the southern and eastern parts of the study area, where the confining unit that divides the middle aquifer is absent.

Simulated and interpreted heads in the lower aquifer are shown in figure 31. Simulated heads were within $10 \mathrm{ft}$ of all measured water levels. Head contours show that the aquifer outcrop and subcrop areas near the Delaware River are primary areas of ground-water recharge. The simulated and interpreted potentiometric surfaces in the lower aquifer are similar in shape and range in altitude from about sea level near the outcrop and subcrop of the aquifer to more than 50 $\mathrm{ft}$ below sea level in West Deptford Township. The shape of the potentiometric surface suggests that lateral ground-water flow in the lower aquifer is southeastward and eastward toward major withdrawal centers located outside the study area (Eckel and Walker, 1986). Local depressions of the potentiometric-surface contour lines near the outcrop and subcrop areas of the aquifer are caused by withdrawals from several wells in Greenwich Township (wells 15-118, 15-109, 15-414, and 15-672) and in Paulsboro Borough (wells 15-220 and 15-439). Large withdrawals from several wells in updip areas in West Deptford Township and in Westville Borough draw down the potentiometric surface sufficiently to produce a cone of depression around major production wells in West Deptford Township (wells 15-314, 15-317, 15-318, 15-319, 15-320, 15-321, and 15-322) and the Westville Borough Water Department wells (wells 15-326, 15-327, and 15-434).

Although the major lateral flow is out of the modeled area along the southern boundary toward southeastern Gloucester County, or eastward toward Camden County, flow into the modeled area occurs along the northern model boundary near withdrawal wells in West Deptford Township and the Westville Borough Water Department wells, and along the southeastern part of the boundary.

Heads generally are slightly higher in the lower part of the middle aquifer than in the lower aquifer (as much as $5 \mathrm{ft}$ higher), indicating that leakage is downward. Leakage is strongly downward in the northeastern part of the study area in West Deptford Township, where heads are as much as $40 \mathrm{ft}$ higher than they are in the lower aquifer. Leakage is upward in the southeastern part of the study area in Mantua and Deptford Townships, where heads are slightly higher in the lower aquifer than in the lower part of the middle aquifer.

\section{Ground-Water Budget}

A ground-water budget is presented for recent (1986) conditions that were computed using ground-water-flow simulation results. The budget (like the model simulation) represents equilibrium conditions. The budget is calculated for the volume of aquifer sediments represented in the ground-water-flow model (figs. 18 and 19) and referred to as the study area. Flow entering and leaving the lateral boundaries of the area was calculated from measured head data and calibrated transmissivity values. The resulting distribution of flow within the model domain was computed by the model. The distribution of flow among aquifers and the amounts of recharge from and discharge to the various types of boundaries are included.

The total inflow and outflow for the Potomac-Raritan-Magothy aquifer system during recent (1986) conditions is about $44 \mathrm{Mgal} / \mathrm{d}$. The six components of the flow budget, as shown in table 2 and in figure 32, are (1) net recharge from precipitation (including recharge through the outcrop of the Merchantville-Woodbury confining unit), (2) ground-water discharge to streams (including wetlands and ponds), (3) ground-water discharge to the Delaware River, (4) induced leakage from the Englishtown aquifer system, (5) ground-water withdrawals, and (6) flow across 
Table 2. Ground-water budget for the Potomac-Raritan-Magothy aquifer system in the Greenwich Township, New Jersey, study area under recent (1986) conditions (in million gallons per day)

$[-$, not applicable $]$

\begin{tabular}{lcc}
\hline Water-budget component & Inflow & Outflow \\
\hline \hline Recharge & 24.76 & -- \\
Leakage & .79 & -- \\
Stream seepage & 9.75 & 9.57 \\
Delaware River & 2.41 & 1.33 \\
Lateral flow & 6.61 & 13.60 \\
Withdrawals & -- & 19.82 \\
Total & 44.32 & 44.32 \\
\hline
\end{tabular}

the lateral boundaries of the study (modeled) area. Very small mass-balance errors (less than 0.2 percent) associated with the budget of each individual aquifer are introduced by the numerical accuracy of the model solution methodology and are negligible.

The major sources of water to the Potomac-Raritan-Magothy aquifer system are recharge from precipitation, which occurs in the aquifer outcrop areas ( 56 percent of total inflow); induced seepage from streams, also in the aquifer outcrop areas (22 percent); flow across the lateral model boundaries ( 15 percent); induced seepage from the Delaware River (5 percent); and downward leakage from the Englishtown aquifer system (less than 2 percent).

Most of the discharge from ground water is to withdrawal wells (45 percent of total outflow) and lateral flow across the model boundaries (31 percent of total outflow), which is likely discharged to wells located outside the study area. Most of the lateral-boundary discharge is along the eastern model boundary toward the downdip parts of the aquifers. Discharge to streams in the aquifer outcrop areas comprises nearly 22 percent of total outflow. Discharge to the Delaware River is only about 3 percent of total outflow.

The effects of ground-water withdrawals on the ground-water-flow budget can be best appreciated when considering that before development all recharge from precipitation in the outcrop area and flow toward the outcrop from downdip discharged to the Delaware River and its tributaries. Under recent conditions, discharge to the Delaware River and its tributaries has decreased significantly and flow to the aquifer has been induced from many reaches. Withdrawals from deep confined aquifers have significantly increased downward ground-water flow. All ground water flows through the upper aquifer; 71 percent of the total flows through the upper part of the middle aquifer, 56 percent flows through the lower part of the middle aquifer, and 40 percent, a significant amount of ground-water flow, penetrates to the lower aquifer. 


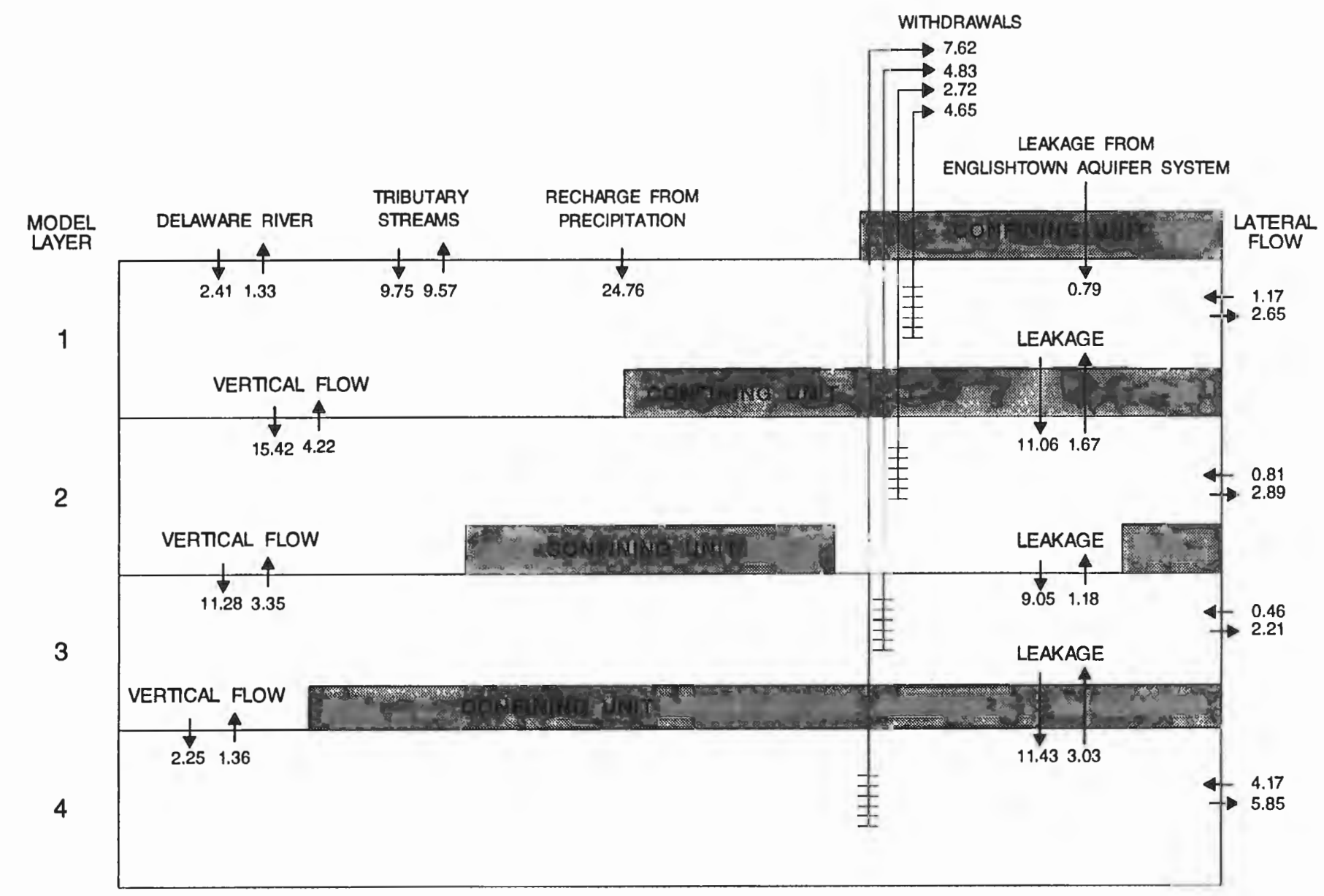

Figure 32. Flow budget for the Potomac-Raritan-Magothy aquifer system in the Greenwich Township, New Jersey, study area under recent (1986) stressed conditions. (Flow rates are in million gallons per day) 
Ground water has an effective pathway for movement to deeper aquifers within the outcrop area where confining units are absent. Most water moving down to both the upper and lower parts of the middle aquifer flows through the aquifer outcrop area, despite the fact that this area is much smaller than the area of the confined part of the aquifer (see figures 29 and 30). Most water entering the lower aquifer must flow through the overlying confining unit because its outcrop is very small (fig. 32). In fact, withdrawals from the lower aquifer and lateral discharge together are 75 percent of total ground-water flow in that aquifer, and control ground-water-flow patterns and rates in the lower aquifer.

\section{Hydrologic Considerations for Additional Ground-Water Development}

The ground-water-flow simulation analysis presented in the previous sections is intended to define the effects of development on the ground-water system under recent (1986) conditions. The analysis addresses how and where pumped wells derive water from the ground-water system, and includes how drawdown propagates within the ground-water system and from what boundaries flow is diverted to the pumped wells. These hydraulic characteristics can be used in conjunction with information on the distribution of ground-water quality provided by Barton and Kozinski (1996) to evaluate qualitatively the best locations for additional ground-water withdrawals.

Simulation results indicate that ground water in unconfined areas at the aquifer outcrops moves at the highest ground-water velocities and is relatively young water. Therefore, water throughout the unconfined area potentially can be affected by contamination from human activities. Increased withdrawals in the outcrop area ideally would be located to derive most water by induced inflow from local streams of good quality or from recharge in areas with land use having low risk of contamination. The Delaware River is fresh throughout most of the year; saline water, however, reaches the southern part of the study area during the summer in an average year and will proceed farther under drought conditions (Anderson and others, 1972). Therefore, the amount of water derived from induced flow from the Delaware River should be evaluated carefully.

Additional withdrawals from the confined aquifers, particularly in downdip areas, have the lowest probability of being affected by contamination from human activities because groundwater velocities are lower and because ground water has traveled much farther since it recharged the aquifer system. Withdrawals from the confined aquifers, however, caused significant drawdown because water is derived either from leakage through confining units, which have very low water-transmitting properties, or from the outcrop area, which is very far away. A result of this factor is that the effects of any one well (in terms of decreased flow at hydrologic boundaries) will be dispersed over a broad area, and not be evident at any single stream or wetland. In fact, drawdown will be greater and flow derived from a broader area progressively as withdrawals are made from deeper aquifers because drawdown must propagate farther and through more confining units before it reaches a hydrologic boundary from which it can derive its flow.

Additional withdrawals from the lower aquifer are limited by the presence of saline ground water (chloride concentration greater than $250 \mathrm{mg} / \mathrm{L}$ ). Saline ground water occurs in the southern and southwestern parts of the study area, in East Greenwich, Greenwich, Harrison, Logan, and Woolwich Townships and Swedesboro (Barton and Kozinski, 1996). An attendant adverse effect of the sensitivity of the deep confined aquifers to withdrawals is that increased drawdown caused greater rates of movement of saline ground water toward the pumped wells. Monitoring for possible updip movement of saline ground water will assist long-term management of water supply. 
Increased flow downward to the aquifer system from the Englishtown aquifer system is not likely to be a significant source of additional water because of the low leakance of the overlying confining unit and the limited extent of the Englishtown aquifer system in the study area. Leakage from the Englishtown aquifer system is less than 2 percent of the ground-water budget under recent conditions.

\section{SUMMARY AND CONCLUSIONS}

The Potomac-Raritan-Magothy aquifer system provides virtually all the water supply within the area of Greenwich Township, Gloucester County, New Jersey. The aquifer system comprises sediments of the Potomac Group, Raritan Formation, Magothy Formation, and upper Cenozoic deposits that overlie all the aforementioned sediments. The Potomac-Raritan-Magothy aquifer system extends eastward from the Fall Line in southeastern Pennsylvania. It deepens to the southeast and thickens to more than $900 \mathrm{ft}$ in the study area. The aquifer system consists of the upper aquifer, the upper and lower parts of the middle aquifer, the lower aquifer, and the associated confining units. Prior to development, ground water flowed toward the outcrop area and discharged to the Delaware River and other streams. Under recent (1986) conditions, withdrawals both within the study area and to the southeast have caused ground water to flow to the southeast away from the outcrop area. Those altered directions of flow threaten to allow migration of industrial contaminants, saline ground water from deep aquifers, and seawater in the Delaware River estuary to public-supply wells.

A three-dimensional model was developed to simulate ground-water flow within the study area during recent (1986) conditions. A quantitative evaluation of the flow system based on results of flow simulations and observed hydrologic information is presented. The hydraulic properties of aquifers and confining units based on reported data (Barton and Kozinski, 1991) and results of the ground-water-flow simulations are presented.

The total water budget of the ground-water system within the study area is 44.3 million gallons per day during recent (1986) conditions. The major sources of inflow are recharge from precipitation (56 percent), inflow from streams (including the Delaware River, 27 percent), and lateral flow within aquifers across the area's borders ( 15 percent). The major outflows are withdrawals (45 percent), lateral flow (primarily to a large center of withdrawals east and south of the study area, 31 percent), and seepage to streams (nearly 25 percent).

The aquifer system is unconfined where the water table occurs in the outcrop or subcrop of the Potomac-Raritan-Magothy aquifer system or in the overlying upper Cenozoic deposits. Water-table altitudes are maintained below sea level in parts of the outcrop area by a system of tidegates on streams that discharge to the Delaware River and by withdrawals designed to control ground-water contamination.

Altitudes of potentiometric surfaces in the confined aquifers range from 0 to $10 \mathrm{ft}$ below sea level in their outcrop areas, and reach more than $50 \mathrm{ft}$ below sea level downdip, in the southeastern part of the study area. Generally, ground water flows from the shallowest to the deepest confined aquifers; flow is driven by withdrawals from all aquifers. Withdrawals within the study area cause local cones of depression and result in upward flow between aquifers in a few local areas.

Ground water throughout the unconfined area is relatively young and potentially could be affected by contamination from human activities. Consideration should be given to limiting withdrawals within the outcrop area to ground water that (1) was recharged in areas not threatened by contamination, (2) seeps from potable reaches of small streams, and (3) is induced to infiltrate from the Delaware River where and (or) when the saltwater front is not present. 
Ground water within the confined aquifers is much less likely to be contaminated from human activities progressively downdip. Withdrawals from within the confined aquifers will have progressively increasing drawdown with depth and ideally would be located to minimize the threat of encroachment of saline ground water from the lower aquifer in the southern and southwestern parts of the study area, and implemented with monitoring to warn of updip migration of saline ground water. 


\section{REFERENCES CITED}

Anderson, P.W., Faust, S.D., and McCall, J.E., 1972, Impact of drought on New Jersey's water resources: American Society of Civil Engineers, Journal of the Irrigation and Drainage Division, Proceedings Paper 9205, v. 98, no. IR3, p. 375-385.

Andres, A.S., 1984, Geology and ground-water flow in the Potomac-Raritan-Magothy aquifer system, Logan Township, New Jersey: Bethlehem, Pa., Lehigh University, unpublished M.S. thesis, $164 \mathrm{p}$.

Balmer, W.T., and Davis, D.K., 1993, Ground-water resources of Delaware County, Pennsylvania: Pennsylvania Department of Environmental Resources Water Resources Report 66, 67 p., $1 \mathrm{pl}$.

Barksdale, H.C., Greenman, D.W., Lang, S.M., Hilton, G.S., and Outlaw, D.E., 1958, Groundwater resources in the tri-state region adjacent to the lower Delaware River: New Jersey Department of Conservation and Economic Development Special Report 13, 190 p.

Barton, Cynthia, and Kozinski, Jane, 1991, Hydrogeology of the region of Greenwich Township, Gloucester County, New Jersey: U.S. Geological Survey Water-Resources Investigations Report 90-4198, 77 p.

Barton, Cynthia, and Kozinski, Jane, 1996, Water quality in the Potomac-Raritan-Magothy aquifer system in the region of Greenwich Township, Gloucester County, New Jersey:

U.S. Geological Survey Open-File Report 95-720, 113 p., 6 pl.

Duran, P.B., 1986, Distribution of bottom sediments and effects of proposed dredging in the ship channel of the Delaware River between northeast Philadelphia, Pennsylvania, and Wilmington, Delaware, 1984: U.S. Geological Survey Hydrologic Investigations Atlas HA-697, scale 1:48,000, 1 sheet.

Eckel, J.A., and Walker, R.L., 1986, Water levels in major artesian aquifers of the New Jersey Coastal Plain, 1983: U.S. Geological Survey Water-Resources Investigations Report 86-4028, 62 p.

Farlekas, G.M., Nemickas, Bronius, and Gill, H.E., 1976, Geology and ground-water resources of Camden County, New Jersey: U.S. Geological Survey Water-Resources Investigations $76-76,146 \mathrm{p}$.

Fenneman, N.M., 1938, Physiography of the eastern United States: New York, McGraw-Hill Book Co., Inc., 714 p.

Forman, R.T.T., 1979, Pine Barrens--Ecosystem and landscape: New York, Academic Press, $601 \mathrm{p}$.

Franke, O.L., and Reilly, T.E., 1987, The effects of boundary conditions on the steady-state response of three hypothetical ground-water systems--Results and implications of numerical experiments: U.S. Geological Survey Water-Supply Paper 2315, 19 p.

Gill, H.E., and Farlekas, G.M., 1976, Geohydrologic maps of the Potomac-Raritan-Magothy aquifer system in the New Jersey Coastal Plain: U.S. Geological Survey Hydrologic Investigations Atlas HA-557, scale 1:500,000, 2 sheets. 


\section{REFERENCES CITED--Continued}

Greenman, D.W., Rima, D.R., Lockwood, W.N., and Meisler, Harold, 1961, Ground-water resources of the Coastal Plain area of southeastern Pennsylvania, with special reference to the effects of human activities on the quality of water in the Coastal Plain sediments: Pennsylvania Geological Survey Bulletin, 4th ser., Bulletin W13, 375 p.

Harbaugh, A.W., Luzier, J.E., and Stellerine, Flavian, 1980, Computer-model analysis of the use of Delaware River water to supplement water from the Potomac-Raritan-Magothy aquifer system in southern New Jersey: U.S. Geological Survey Water-Resources Investigations 80-31, $41 \mathrm{p}$.

Hardt, W.F., and Hilton, G.S., 1969, Water resources and geology of Gloucester County, New Jersey: New Jersey Department of Conservation and Economic Development Special Report 30, $130 \mathrm{p}$.

Jorgensen, D.G., Signor, D.C., and Imes, Jeffrey, 1989, Accounting for intercell flow in models with emphasis on water table recharge and stream-aquifer interaction--1. Problems and concepts: Water Resources Research, v. 25, no. 4, p. 669-676.

Keith, L.H., and Telliad, W.A., 1979, Priority pollutants, I--A perspective view: Environmental Science and Technology, v. 13, no. 4, April 1979, p. 416-423.

Kozinski, Jane, Lacombe, P.J., Hochreiter, J.J., Jr., and Lewis, J.C., 1990, Geophysical and chemical investigations of ground water at five industrial or waste-disposal sites in Logan Township, Gloucester County, New Jersey, 1983-87: U.S. Geological Survey WaterResources Investigations Report 90-4004, 131 p.

Lacombe, P.J., and Rosman, Robert, 1995, Hydrology of the unconfined aquifer system in the upper Maurice River basin and adjacent areas in Gloucester County, New Jersey, 1986-87: U.S. Geological Survey Water-Resources Investigations Report 92-4128, 5 sheets.

Lewis, J.C., Hochreiter, J.J., Jr., Barton, G.J., Kozinski, Jane, and Spitz, F.J., 1991, Hydrogeology of, and ground-water quality in, the Potomac-Raritan-Magothy aquifer system in the Logan Township region, Gloucester and Salem Counties, New Jersey: U.S. Geological Survey Water-Resources Investigations Report 90-4142, 92 p., 11 pls.

Luzier, J.E., 1980, Digital-simulation and projection of head changes in the Potomac-RaritanMagothy aquifer system, Coastal Plain, New Jersey: U.S. Geological Survey WaterResources Investigations $80-11,72 \mathrm{p}$.

Martin, Mary, in press, Simulation and evaluation of flow in the major aquifers of the New Jersey Coastal Plain: U.S. Geological Survey Professional Paper 1404-H.

McDonald, M.G., and Harbaugh, A.W., 1988, A modular three-dimensional finite-difference ground-water flow model: U.S. Geological Survey Techniques of Water-Resources Investigations, book 6, chap. A1, $586 \mathrm{p}$.

Navoy, A.S., and Carleton, G.B., 1995, Ground-water flow and future conditions in the PotomacRaritan-Magothy aquifer system, Camden area, New Jersey: New Jersey Geological

- Survey Geological Survey Report 38, 184 p. 


\section{REFERENCES CITED--Continued}

Owens, J.P., and Minard, J.P., 1979, Upper Cenozoic sediments of the lower Delaware valley and the northern Delmarva Peninsula, New Jersey, Pennsylvania, Delaware, and Maryland: U.S. Geological Survey Professional Paper 1067-D, 47 p.

Owens, J.P., Minard, J.P., Sohl, N.F., and Mello, J.F., 1970, Stratigraphy of the outcropping postMagothy Upper Cretaceous formations in southern New Jersey and northern Delmarva Peninsula, Delaware and Maryland: U.S. Geological Survey Professional Paper 674, $60 \mathrm{p}$.

Parker, G.G., Hely, A.G., Keighton, W.B., Olmsted, F.H., and others, 1964, Water resources of the Delaware River basin: U.S. Geological Survey Professional Paper 381, 200 p.

Paulachok, G.N., and Wood, C.R., 1984, Water-table map of Philadelphia, Pennsylvania, 1976-1980: U.S. Geological Survey Hydrologic Investigations Atlas HA-676, scale 1:50,000, 1 sheet.

Pucci, A.A., Jr., and Murashige, J.E., 1987, Applications of universal kriging to an aquifer study in New Jersey: Ground Water, v. 25, no. 6, p. 672-678.

Pucci, A.A., Jr., Pope, D.A., and Gronberg, J.M., 1994, Hydrogeology, simulation of regional ground-water flow, and saltwater intrusion, Potomac-Raritan-Magothy aquifer system, northern Coastal Plain of New Jersey: New Jersey Geological Survey Geological Survey Report 36, 209 p.

Richards, H.G., Olmstead, F.H., and Ruhle, J.L., 1962, Generalized structural contour maps of the New Jersey Coastal Plain: New Jersey Department of Conservation and Economic Development Geologic Report Series 4, 38 p.

Rosenau, J.C., Lang, S.M., Hilton, G.S., Rooney, J.G., 1969, Geology and ground-water resources of Salem County, New Jersey: New Jersey Department of Conservation and Economic Development Special Report 33, 142 p.

Rosman, Robert, Lacombe, P.J., and Storck, D.A., 1995, Water levels in major artesian aquifers of the New Jersey Coastal Plain, 1988: U.S. Geological Survey Water-Resources Investigations Report 95-4060, 74 p., 8 pl.

Sloto, R.A., 1986, Simulation of ground-water flow in the lower sand unit of the Potomac-RaritanMagothy aquifer system, Philadelphia, Pennsylvania: U.S. Geological Survey WaterResources Investigations Report 86-4055, 52 p.

Vowinkel, E.F., 1984, Ground-water withdrawals from the Coastal Plain of New Jersey, 1956-80: U.S. Geological Survey Open-File Report 84-226, 32 p.

Winograd, I.J., and Farlekas, G.M., 1974, Problems in C dating of water from aquifers of deltaic origin--An example from the New Jersey Coastal Plain, in Isotope techniques in groundwater hydrology, 1974, v. II: International Atomic Energy Agency, Vienna, p. 69-83.

Zapecza, O.S., 1989, Hydrogeologic framework of the New Jersey Coastal Plain: U.S. Geological Survey Professional Paper 1404-B, 49 p., 24 pls. 


\section{REFERENCES CITED--Continued}

Zapecza, O.S., Voronin, L.H., and Martin, Mary, 1987, Ground-water-withdrawal and water-level data used to simulate regional flow in the major Coastal Plain aquifers of New Jersey:

U.S. Geological Survey Water-Resources Investigations Report 87-4038, 120 p. 